\title{
30. VARIATIONS IN SURFACE WATER MASS CONDITIONS IN THE NORWEGIAN-GREENLAND SEA: EVIDENCE FROM PLIOCENE/PLEISTOCENE CALCAREOUS PLANKTON RECORDS $(\text { SITES 644, 907, 909) })^{1}$
}

\author{
Karl-Heinz Baumann, ${ }^{2}$ Helge Meggers, ${ }^{2}$ and Rüdiger Henrich ${ }^{2}$
}

\begin{abstract}
Records of bulk carbonate content, calcareous plankton assemblages, as well as sedimentological data from Ocean Drilling Program Sites 644, 907, and 909 are used to examine past variations in the surface circulation system of the Norwegian-Greenland Sea. This study includes investigations of the species abundance as well as the preservation of planktonic foraminifer species Neogloboquadrina pachyderma.

In general, the Sites 644 and 907 data indicate an intensification of glaciation 3.0 m.y. (Iceland Sea) and 2.75 m.y. (Norwegian Sea) ago. The interval until $\sim 1.1 \mathrm{Ma}$ is marked by a series of changes in surface water environments. Weak but still recognizable northward penetrations of relatively warm Atlantic Ocean water reached the Norwegian Sea (Site 644) several times, although glacial conditions dominated. However, the interval 1.65 to $1.4 \mathrm{Ma}$ at Site 644 is characterized by a first considerable warming of the surface water conditions. Relatively high amplitudes in the biogenic calcareous records and abundant warmadapted species indicate the presence of relatively warm surface waters during interglacials, whereas low numbers of microfossils are related to conditions dominated by sea-ice cover during glacials. In addition, the nannoplankton and foraminifer assemblages are characterized by well-preserved subpolar species during climatic optima, although cold-adapted species dominated throughout this interval. However, the Iceland Sea and the Fram Strait were uninfluenced by the relatively warm precursor of the Norwegian Current. A significant decrease in the numbers of calcareous nannofossils and planktonic foraminifers at $1.4 \mathrm{Ma}$ is related to another cooling that lasted until $\sim 1.1 \mathrm{Ma}$. The last $1.1 \mathrm{~m} . \mathrm{y}$. records a continuous intensification of the glacial to interglacial contrasts, reflecting a strengthening of the Norwegian Current. Warm surface water intruded into the Iceland Sea now, which is indicated by the relatively high abundances of calcareous plankton assemblages at Site 907 . In the Fram Strait, planktonic foraminifer assemblages first appeared after 0.8 Ma. The amplitude of glacial to interglacial conditions further increased at $\sim 0.65 \mathrm{Ma}$. In general, the highest amplitude shifts in the biogenic calcareous records are observed during this interval.

Carbonate preservation generally is in good accordance with the overall trend toward amplified glacial to interglacial contrasts throughout the last $3.1 \mathrm{~m}$.y. In the late Pliocene carbonate is well preserved. The period from $\sim 2.75$ to $1.65 \mathrm{Ma}$ is characterized by widespread strong dissolution. A considerable improvement in carbonate preservation at $\sim 1.65$ to $1.4 \mathrm{Ma}$ is coupled with a first increased northward heat transport, possibly indicating increased deep-water production in the Norwegian Sea. Strong carbonate dissolution indicates a major reduction in deep-water formation during the interval 1.4 to $1.1 \mathrm{Ma}$. With increased advection of temperate Atlantic surface water, the magnitude of deep-water production in the Norwegian-Greenland Sea increased during the past $1.1 \mathrm{~m} . \mathrm{y}$.
\end{abstract}

\section{INTRODUCTION}

The circulation system in the northern North Atlantic has a strong impact on both the climate on the neighboring continents and the storage of carbon in the ocean. Much of the world's deep water is formed in this region, which also has played an important role in the long-term evolution of the global climate. A gradual long-term cooling trend in the Northern Hemisphere since the late Miocene is documented by sporadic occurrences of minor quantities of ice-rafted debris (IRD) in various Norwegian-Greenland Sea and North Atlantic drill sites (Korstgaard and Nielsen, 1989; Bohrmann et al., 1990; Jansen et al., 1990; Jansen and Sjøholm, 1991; Wolf and Thiede, 1991; Henrich and Baumann, 1994). This evidence points to the existence of periods when glaciers were able to form and reach the shelves somewhere in the subarctic. At the Vøring Plateau, the oldest pulses of glacially derived ice-rafted detritus date back to $\sim 12.6 \mathrm{Ma}$, indicating that glaciers for the first time reach sea level at this time (Fronval

Thiede, J., Myhre, A.M., Firth, J.V., Johnson, G.L., and Ruddiman, W.F. (Eds.) 1996. Proc. ODP, Sci. Results, 151: College Station, TX (Ocean Drilling Program).

${ }^{2}$ Fachbereich Geowissenschaften, Bremen University, Postfach 330440 , D-28334 Bremen, Federal Republic of Germany. khb@mail.sedpal.uni-bremen.de and Jansen, this volume). Minor amounts of IRD were also found in northern North Atlantic and Nordic Sea sediments between 9.0 Ma and 7.0 Ma (Korstgaard and Nielsen, 1989; Wolf and Thiede, 1991), at 5.5, 5.1, and 4.5 Ma, and more frequently between 4.0 Ma and 2.8 Ma (Jansen et al., 1990; Wolf and Thiede, 1991). An initial major cooling occurred at $\sim 3.2$ to $3.1 \mathrm{Ma}$ (Prell, 1984; Backman and Pestiaux, 1987; Raymo et al., 1987), when continental ice sheets probably began to grow over large areas of the Northern Hemisphere. However, several detailed studies of the Norwegian-Greenland Sea and North Atlantic have shown that significant ice-rafting first occurred close to the interval from 2.75 to $2.5 \mathrm{Ma}$ (Shackleton et al., 1984; Keigwin, 1987; Ruddiman et al., 1986; Henrich et al., 1989; Raymo et al., 1989; Bohrmann et al., 1990; Baumann and Meggers, in press; Fronval and Jansen, this volume). Major paleoceanographic and paleoclimatic changes evidenced by shifts in facies successions and sediment parameters at Leg 104 drill sites have already been proposed from the long-term record in the Norwegian Sea during the last 2.75 m.y. (Jansen et al., 1988; Henrich, 1989; Krissek, 1989). Records of biogenic and terrigenous components of Ocean Drilling Program (ODP) Sites 643 and 644 were used to reconstruct surface and deep-water regimes in the Norwegian Sea (Henrich and Baumann, 1994).

The present-day Norwegian-Greenland Sea is characterized by strong meridional gradients of the surface water system (e.g., Swift, 
1986). The eastern Norwegian-Greenland Sea margin is ice-free due to the relatively warm and high-salinity Norwegian Current (NC), a northward branch of the North Atlantic Drift. The NC is sufficiently cooled on its way to the Fram Strait to allow deep-water formation within the cyclonic gyre of the Greenland Sea. The outflow is via the cold and low-salinity East Greenland Current (EGC), which carries the polar water out of the Arctic southward along the East Greenland margin to the North Atlantic (Fig. 1). Between the regions dominated by the polar (EGC) and the Atlantic water masses (NC), the so-called Arctic surface water forms as a mixture of both. The Arctic surface water is contained in two cyclonic gyres, formed by the Jan Mayen Current and the East Iceland Current. The system of warm and cold water masses results in the formation of distinct oceanographic fronts (Johannessen, 1986).

The downcore variations in the carbonate content are supposed to reflect variations in carbonate productivity that result mainly from changes in the inflow of warm Atlantic surface water masses. Differences in carbonate content of the sediments have often been used to distinguish the surface water masses in the Norwegian-Greenland Sea (Kellogg, 1975, 1976; Hęnrich et al., 1989; Baumann et al., 1993; Henrich and Baumann, 1994). High contents of planktonic foraminifers and coccolithophorids are found in the water masses of the Norwegian Current (Samtleben and Schröder, 1992). Low production and relatively high dissolution of $\mathrm{CaCO}_{3}$ characterize the polar surface water masses (Hebbeln and Wefer, 1991; Carstens and Wefer, 1992; Samtleben and Schröder, 1992). A perennial ice cover strongly restricts the productivity of planktonic calcareous biota (Hebbeln and Wefer, 1991). Thus, low calcium carbonate contents in sediments are interpreted to reflect cold, often ice-covered surface water masses. In addition, the biogeographical distribution of calcareous nannoplankton and planktonic foraminifers is related to the properties of surface water masses (Bé, 1977; Samtleben and Schröder, 1992; Samtleben et al., 1995). Neogloboquadrina pachyderma sin. is perhaps the most significant planktonic foraminifer of cold, polar surface water masses today, and high-latitude foraminiferal assemblages are usually dominated by this species. Among the coccolithophorids generally considered to be good temperature indicators, Coccolithus pelagicus (Wallich) Schiller is well known as a cold water species. Its temperature range has even been shown to include negative temperature values (Braarud, 1979; Samtleben et al., 1995).

The main objective of this study is to present records of bulk carbonate, calcareous plankton assemblages, and some sedimentological proxy data of Sites 644,907 , and 909, to reconstruct the variability of the surface circulation system in the Norwegian-Greenland Sea during the last $3.1 \mathrm{~m} . y$. We primarily used microfossil abundance and assemblage composition to better understand the response of the calcareous planktonic organisms to Northern Hemisphere cooling with respect to changes in regional ice extension and surface ocean circulation. Another aspect of this study includes variations in deep water properties, which are derived from carbonate preservation studies. In general, comparison of different sites of the Norwegian-Greenland Sea allows us to better understand linkages of oceanographic changes along east-west and north-south transects.

\section{MATERIAL AND METHODS Samples}

Samples for carbonate measurements and calcareous component analysis were taken at ODP Holes 644A, 907A, 909A, and 909C (Appendix). Site 644 was drilled on the Vøring Plateau by ODP Leg 104. It is located under the main flux of the relatively warm Norwegian Current and, thus, it is the one suitable for being a reference site for the influx of North Atlantic surface water into the Norwegian-Greenland Sea. Site 907 is located on the central Iceland Plateau and Site 909 is in the central Fram Strait. Thus, south-north and east-west gra-

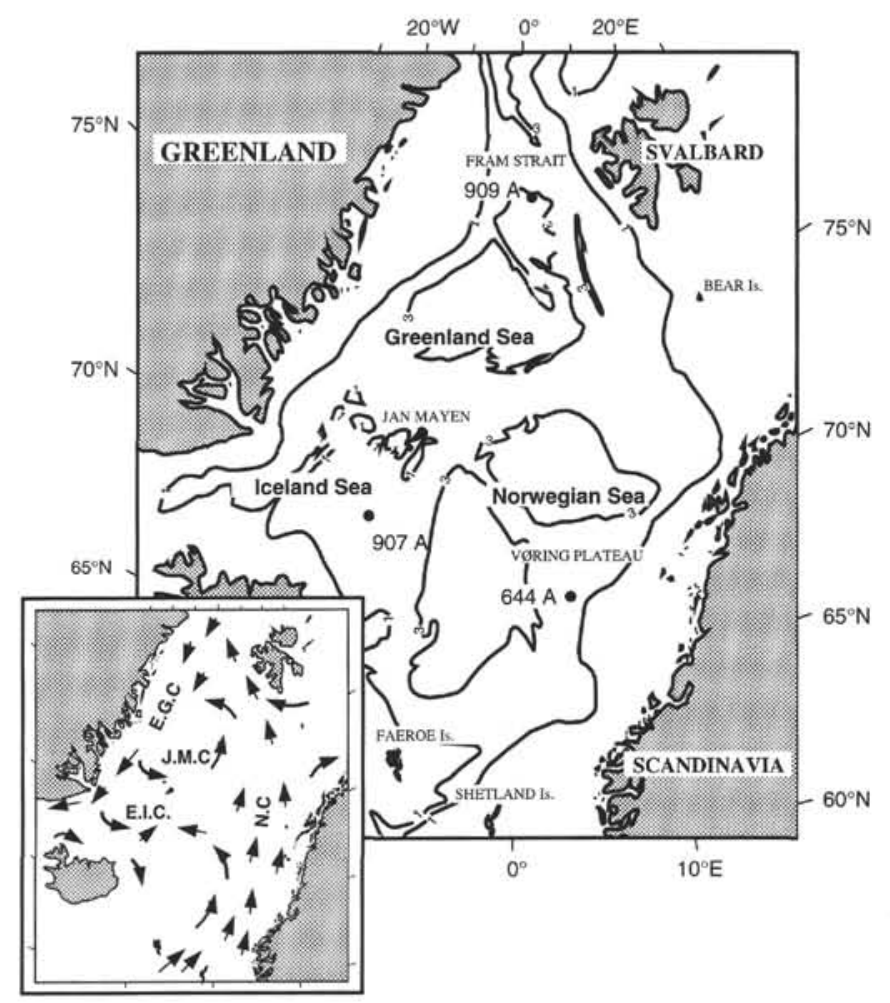

Figure 1. Location of Holes 644A, 907A, and 909A in the Norwegian-Greenland Sea and present-day major surface water circulation (E.G.C. = East Greenland Current, J.M.C. = Jan Mayen Current, E.I.C. = East Iceland Current, and N.C. = Norwegian Current). Bathymetry in kilometers.

dients within the Norwegian-Greenland Sea were distinguished. The locations of the ODP sites used in this study are shown in Figure 1.

The basic data for this study are from sediment samples taken at 10- to $40-\mathrm{cm}$-depth intervals from the uppermost cores (corresponding to the last $1.1 \mathrm{~m} . \mathrm{y}$.) of all investigated sites. The stratigraphic resolution of these samples varies between the sites, but is usually between 3000 and 5000 years for bulk carbonate measurements and less than 10,000 years for faunal and floral data. Sample resolution decreased in the deeper cores and is more scattered than it is in the upper parts of the holes. Parts of the data from Site 644 were already published.

\section{Carbonate and Calcareous Components}

A LECO CS-125 infrared analyzer was used to measure the total carbon (TC) and total organic carbon (TOC) content of bulk sediments. Calcium carbonate content was calculated in weight percentages of the bulk sample by:

$$
\mathrm{CaCO}_{3} \%=(\mathrm{TC} \%-\mathrm{TOC} \%) \times 8.33 \text {. }
$$

Previously published $\mathrm{CaCO}_{3}$ data from the upper $250.0 \mathrm{mbsf}$ of Site 644 (Henrich et al., 1989) were improved by 104 additional measurements (Appendix Table 1.1).

Sediment samples were freeze-dried, weighed, and washed on a 63- $\mu \mathrm{m}$ mesh, and then further split into subfractions. The total abundance of planktonic foraminifers was determined, and specimens counted in the 125 - to $500-\mu \mathrm{m}$ fraction. Samples were split into aliquots of at least 300 specimens. Samples with less than 300 specimens were counted completely. Total foraminifer abundances were 
converted to "specimens per gram dry weight sediment." Total numbers of benthic foraminifers were also counted, using the same procedure.

To count coccoliths under the SEM, the sediments were cleaned of the clay fraction (see Baumann, 1990). For quantitative analysis, micrographs of an arbitrarily selected part of the scanned sample were taken and all particles (usually $>1500$ particles) were counted. Thus, up to 500 coccoliths were counted in each sample using $2000 \times$ magnification. The quantitative data were recorded as particle percent (grain percent of $<63-\mu \mathrm{m}$ fraction) for coccolith species.

\section{Carbonate Preservation}

Preservation of Neogloboquadrina pachyderma sin. tests (usually 40 tests) was studied under the SEM. The five-step progressive stages of dissolution ( $0=$ undissolved, $4=$ strongly dissolved $)$ of two principal surface types were distinguished. Reticulate tests are composed of small nannocrystals in a tiny, primary microcrystalline layer and a secondary agglomerated layer with crystals arranged in diffuse palisades, whereas a crystalline morphotype develops a tertiary calcitic crust composed of large rhombohedrons on its surfaces. This crust may completely or partly cover the outer surface. The differentiation between morphotypes in dissolution studies is important because of the lower preservation potential of the microgranular morphotype relative to the crystalline one. Finally, a composite dissolution index was calculated for each sample (see Henrich, 1989; Baumann and Meggers, in press).

\section{Stratigraphy}

The chronostratigraphy is primarily based on oxygen isotope data for the Brunhes Chron section at Sites 644 and 907 (Fronval and Jansen, this volume). Paleomagnetic measurements provide the stratigraphic control for the deeper cores of these sites, especially the section from 83.45 to 250.0 mbsf of Site 644 (Henrich and Baumann, 1994) and the section from 16.15 to 59.5 mbsf of Site 907 (Myhre, Thiede, Firth, et al., 1995). The time scale for Holes 909A and 909C was primarily determined on the basis of the identification of magnetic reversal boundaries.

The depths of each sample were calculated as midpoints of the depth ranges at which each time scale control point occurs. Ages were derived by linear interpolation between the paleomagnetic reversal boundaries. All ages, including previously published ages, were converted to the time scale of Shackleton et al. (1995), who improved the time scale for the last 6 m.y. by astronomically tuning the GRAPE and oxygen isotope records from ODP Leg 138.

\section{RESULTS Site 644}

The carbonate records at Hole 644A (Appendix Table 1.1) are the only ones suitable for a continuous paleoclimatic interpretation of the Norwegian-Greenland Sea. In the section below $238.4 \mathrm{mbsf}$, relatively high carbonate contents are observed with a clear predominance of calcareous nannofossils (Fig. 2). Although planktonic foraminifers are rare within this interval, specimens are generally well preserved (dissolution indices $<1.5$ ). Between 238.4 and 156.5 mbsf, maximum carbonate contents are usually less than $10 \mathrm{wt} \%$ and long sections are almost barren in carbonate. In addition, only a few samples contain low numbers of relatively well-preserved planktonic and benthic foraminifers ( $<500 \mathrm{spec} / \mathrm{g})$ as well as calcareous nannofossil species. Increased carbonate values of $>20 \mathrm{wt} \%$ were observed between 156.5 and 139.9 mbsf. However, only very low contents of well-preserved planktonic foraminifers were observed, whereas the number of calcareous nannofossils conspicuously increased in this interval. The assemblages usually were dominated by the cold-water species Cocco- lithus pelagicus, but they also consist of the relatively eurythermal species Calcidiscus leptoporus, Pseudoemiliania lacunosa, and Reticulofenestra spp. together with minor amounts of other species. The section from 149.9 to 110.6 mbsf shows a pattern similar to that observed in the section below $156.5 \mathrm{mbsf}$. Carbonate contents are generally $<10 \mathrm{wt} \%$ and only very few poorly preserved planktonic foraminifers were observed. Furthermore, this section is barren in calcareous nannofossils.

The upper 110.6 mbsf of sediment is characterized by moderate carbonate contents, exceeding $20-30 \mathrm{wt} \%$. Carbonate minima are generally below $10 \mathrm{wt} \%$. Within the interval between 110.6 and 73.0 mbsf, relatively low contents of benthic and planktonic foraminifers were observed. In addition, relatively low numbers of calcareous nannofossils were observed, although a single peak with high abundance of coccoliths was found at $85.5 \mathrm{mbsf}$. The assemblage is dominated by Gephyrocapsa spp. associated by minor occurrences of $C$. leptoporus. Carbonate dissolution in the latest Matuyama (110.6$73.0 \mathrm{mbsf}$ ) is much higher than observed in the uppermost sections. Evidence for extensive glacial-interglacial cyclicity is found in the upper $73.0 \mathrm{mbsf}$ of the core. Calcareous plankton organisms were abundant especially in interglacial stages, whereas during glacials sediments are nearly or totally barren in biogenic carbonate. Neogloboquadrina pachyderma sin. clearly dominated this interval, whereas subpolar planktonic foraminifers only had one peak occurrence $(\approx 700 \mathrm{spec} . / \mathrm{g})$ at $15.1 \mathrm{mbsf}$ (Fig. 2). The nannofossil assemblages are not only marked by the highest amounts of coccoliths but are also characterized by the dominant occurrences of species of the genus Gephyrocapsa. In the uppermost section an overall better carbonate preservation is recorded than in the deeper sediment sections (Fig. 2). Nevertheless, a number of short-termed dissolution peaks with indices of up to 4 occur; they are mostly combined with diamicton deposition (Henrich and Baumann, 1994).

\section{Site 907}

The carbonate record of the Matuyama and upper Gauss chrons (60.5-16.8 mbsf) is characterized by very low amounts of carbonate, generally $<3 \mathrm{wt} \%$ (Fig. 3; Appendix Table 1.2). Carbonate peaks at 45.8 and $58.3 \mathrm{mbsf}$ exceed 30 and $58 \mathrm{wt} \%$, respectively. The high carbonate content at $58.3 \mathrm{mbsf}$ originates in part from calcareous nannoplankton. An assemblage nearly exclusively composed of the cold-water adapted species Coccolithus pelagicus was found, whereas no planktonic foraminifers were observed. The other high carbonate peak at 45.8 mbsf most probably originates from reworked carbonate particles but not from pelagic biogenous particles. Very few planktonic foraminifers were found within the upper sections of this interval (30.5-16.8 mbsf), but the specimens are relatively well preserved (dissolution indices $<3$ ).

A much more species-rich foraminifer assemblage with a dominance of relatively well-preserved Neogloboquadrina pachyderma sin. was found in the uppermost $16.8 \mathrm{mbsf}$ (Fig. 3). The planktonic foraminifer assemblage within this interval is characterized by relatively strong variability, and abundances of up to $>20,000 \mathrm{spec} / \mathrm{g}$ sediment are observed. Carbonate preservation within the uppermost interval is better than is observed in the older intervals. Nevertheless, fluctuation during this period is relatively high (dissolution indices $1-4)$. The calcareous nannofossil assemblage in the uppermost 16.8 mbsf is usually dominated by Gephyrocapsa spp. The total abundance varies strongly, and distinct abundance peaks up to 20 grain\% are observed (Fig. 3). Calcareous nannofossils were abundant especially in interglacial stages, whereas during glacials sediments are nearly or totally barren.

\section{Site 909}

Both the Matuyama and upper Gauss carbonate record of Site 909 (247.5-42.4 mbsf) are characterized by low but significant carbonate 


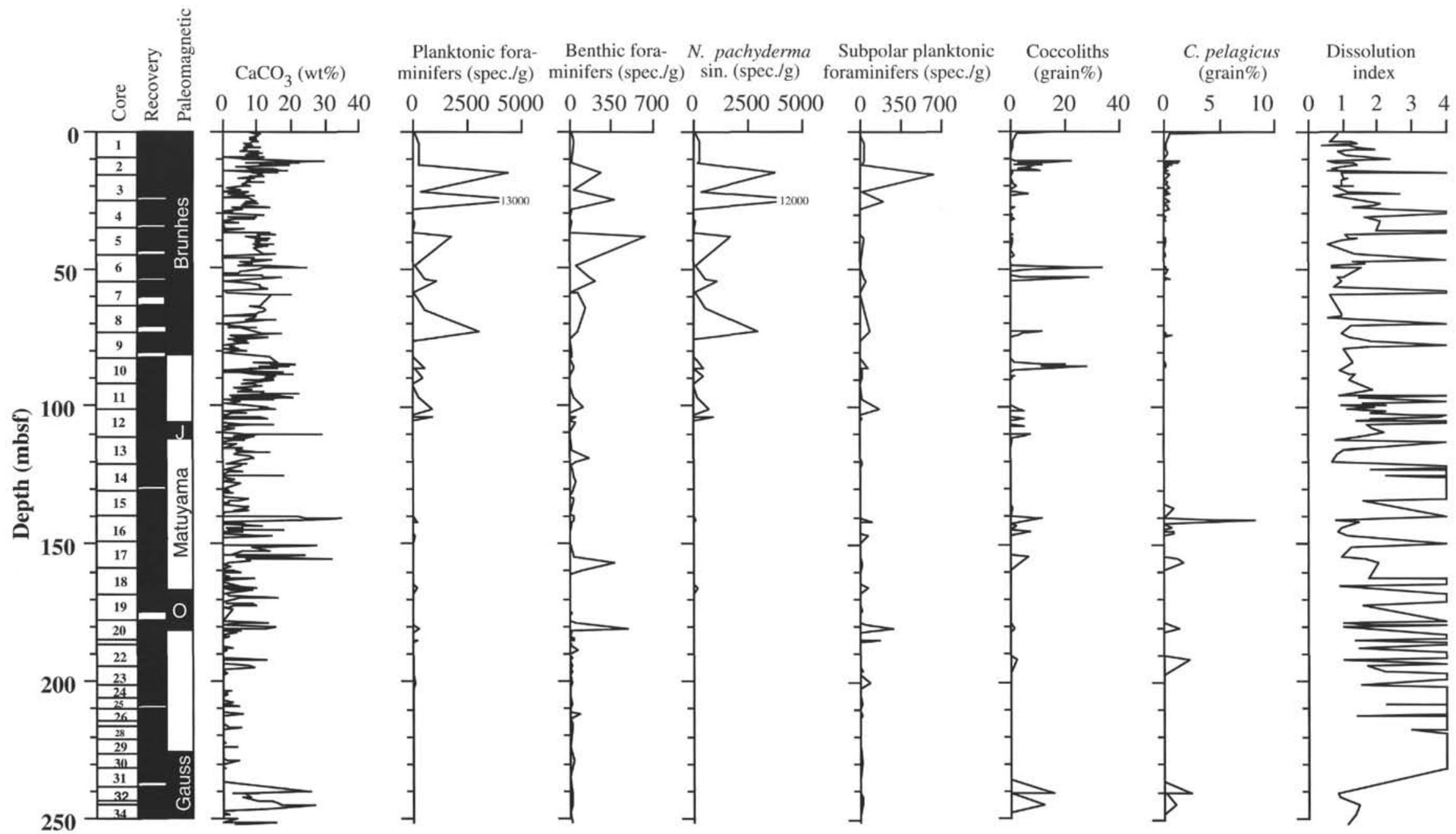

Figure 2. Records of bulk carbonate, faunal and floral data, preservation of planktonic foraminifers, and paleomagnetics at Site 644. 


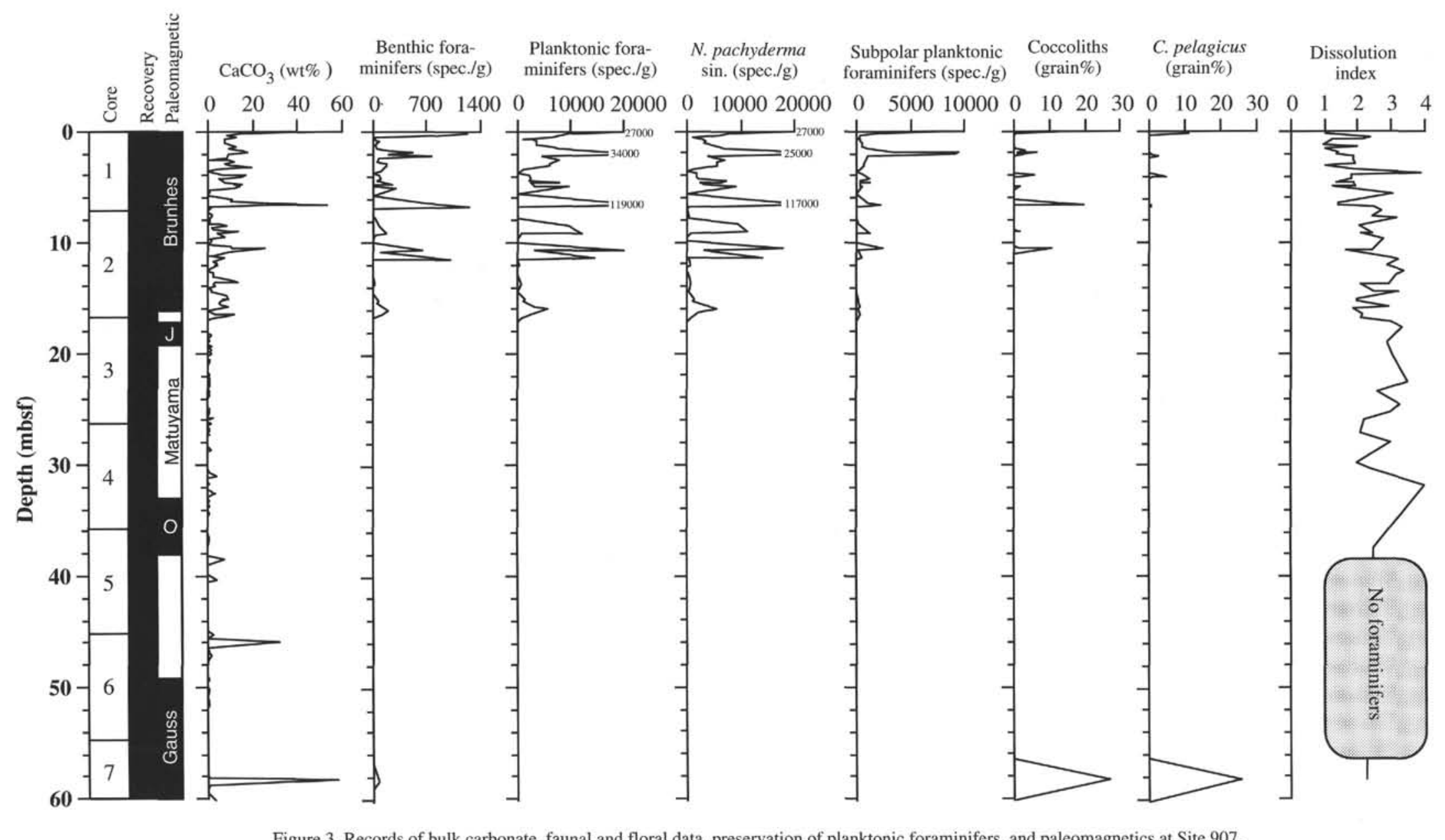


contents interrupted by several carbonate peaks exceeding $30 \mathrm{wt} \%$ (Fig. 4; Appendix Table 1.3). This is similar to the Hole 907A carbonate record. However, foraminifers and calcareous nannofossils were not found within the whole interval. The carbonate peaks most probably originate from reworked carbonate particles. Several calcareous deposits of the Paleocene from the North Greenland Wandel Sea Basin (Håkansson and Stemmerik, 1984) could be the source area of such detrital carbonates. Pelagic biogenic sediments were limited to the uppermost $\sim 42.4 \mathrm{mbsf}$. Horizons having a significant content of planktonic foraminifers alternate with horizons lacking calcareous particles. The numbers of subpolar planktonic foraminifers never exceed $800 \mathrm{spec} . / \mathrm{g}$ sediment. In addition, low amounts of calcareous nannofossils (dominated by Coccolithus pelagicus) were only found in two thin horizons at $0.5-0.7 \mathrm{mbsf}$ and $2.8-3.1 \mathrm{mbsf}$.

\section{DISCUSSION}

Generally, the growth and decay of the Quaternary ice sheets are some of the most striking features of the Earth's climate. At high northern latitudes, large-scale glaciations started at $\sim 2.9-2.7 \mathrm{Ma}$ (Jansen et al., 1988; Henrich et al., 1989; Raymo et al., 1989). However, a number of studies have suggested earlier glacial activities (e.g., Schaeffer and Spiegler, 1986; Jansen et al., 1990; Wolf and Thiede, 1991). IRD records from both the Iceland and Vøring Plateaus suggest a significant intensification of glaciation at $\sim 6 \mathrm{Ma}$, which seems to reflect the onset of middle-sized glaciation in the Northern Hemisphere (Jansen and Sjøholm, 1991; Fronval and Jan- sen, this volume). Between 6 and 3 Ma the size of these middle-sized ice sheets also varied as indicated by highly variable amounts of IRD. However, both the location of the earlier ice sheets and the kind of glaciation remained uncertain.

The paleoenvironmental changes of the Norwegian Sea during the past $2.75 \mathrm{~m}$.y. have already been presented in several previously published studies (Jansen et al., 1988, 1989; Henrich, 1989; Henrich and Baumann, 1994). Their principal conclusions of a stepwise development of the surface water mass conditions with shifts toward warmer interglacials and more extensive glaciation during glacials are supported by the present study. In addition, when comparing the reconstructed glaciation record of western Scandinavia with the IRD record of the sediment cores (Baumann et al., 1995), the general coincidence of maximum glaciations and maximum IRD input is striking. However, minor glacier advances are reflected mainly by reduced carbonate content, but not by strong IRD input. This may indicate cooling events, which are mainly characterized by reduced bioproduction. Thus, low carbonate contents in glacial sediments generally are interpreted to reflect cold, often ice-covered surface water masses. In contrast, high carbonate contents during interglacials reflect a stronger inflow of warm North Atlantic surface water (e.g., Jansen et al., 1988, 1989; Henrich et al., 1989; Baumann et al., 1993, 1995; Henrich and Baumann, 1994).

\section{Paleoceanographic Evolution, 3.1 Ma to 1.1 Ma}

In general, the data from Sites 644 and 907 indicate an intensification of the glacial regime close to $3.0 \mathrm{Ma}$ (Iceland Sea) and 2.75

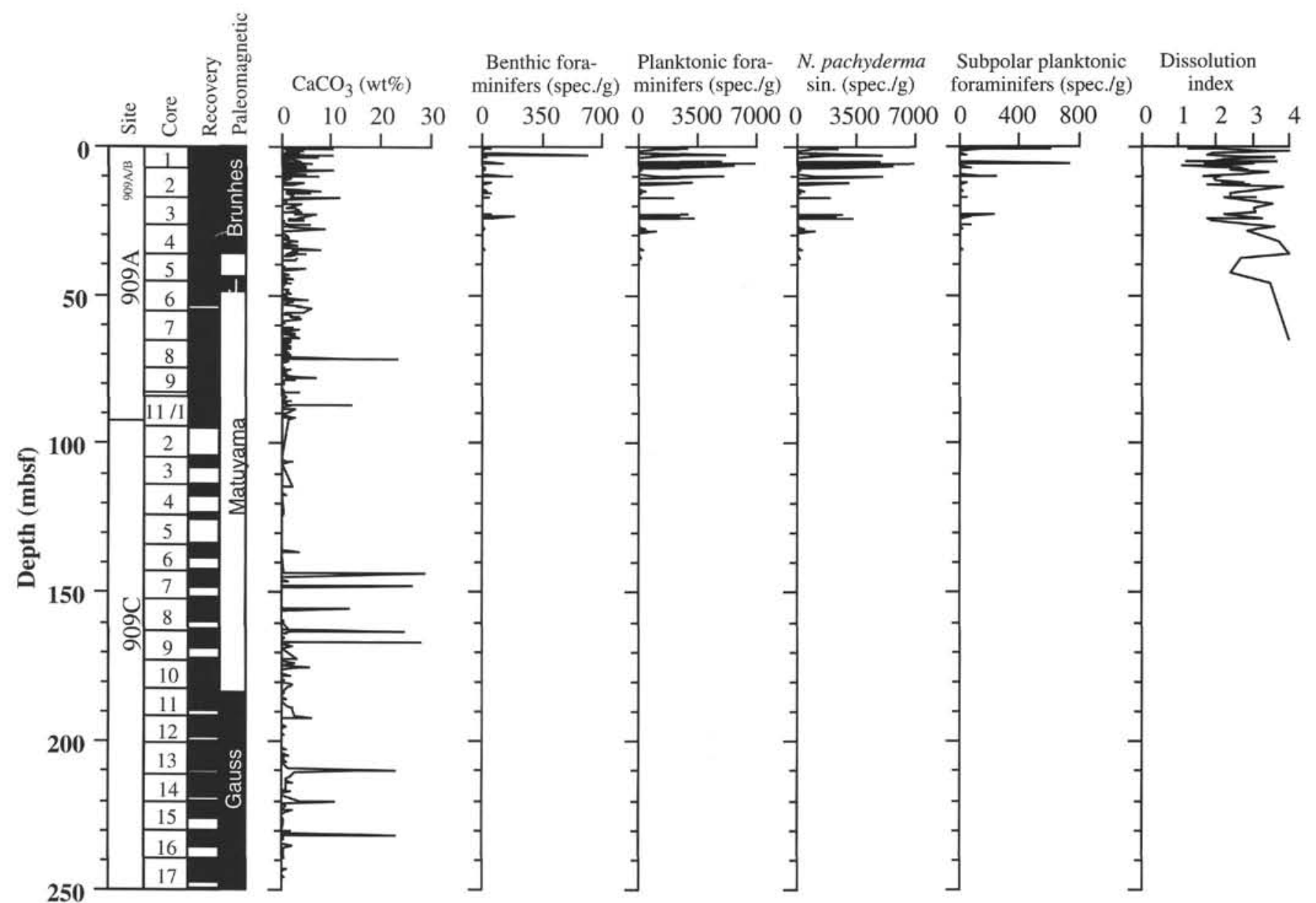

Figure 4. Records of bulk carbonate, planktonic and benthic foraminifer numbers, abundances of $N$. pachyderma sin. and subpolar species (specimens per gram sediment), and the preservation of planktonic foraminifers at Site 909. 
Ma (Norwegian Sea) ago (Figs. 5, 6). However, the preglacial pelagic fauna and flora already was limited to a nearly monospecific assemblage of cold-water adapted coccolithophorid species Coccolithus pelagicus. Planktonic fauna of the North Atlantic indicate warmer sea surface temperatures before this intensification of Northern Hemisphere glaciation (Raymo et al., 1987; Loubere and Moss, 1986; Dowsett and Poore, 1990). However, Shackleton et al. (1984) already demonstrated that considerable climatic variability existed prior to the initial glacial event, and Backman et al. (1986) reported both marked variability of warm-adapted Discoaster spp. abundance and drastically decreasing accumulation rates of discoasters in DSDP Hole 552A during the interval 3.6 to $2.5 \mathrm{Ma}$. The onset of significant Northern Hemisphere glaciation is much better defined by the major increase in the amount of ice-rafted sediments. This increase in IRD input occurred at $2.75 \mathrm{Ma}$ at the Vøring Plateau (Jansen et al., 1988; Henrich et al., 1989; Wolf and Thiede, 1991; Fronval and Jansen, this volume) and at $\sim 2.9 \mathrm{Ma}$ at the Iceland Plateau (Fronval and Jansen, this volume), which is in good accordance to the datums derived by decreased carbonate accumulation (Site 644) and a decrease in calcareous nannofossils (Fig. 5).

Generally, a gradual increase in the buildup of continental ice and a time-transgressive southward penetration of the sea-ice distribution can be seen. The Fram Strait and the Greenland continental margin were heavily influenced by ice-rafted sediments since at least 7.5 to 7.0 Ma (Larsen et al., 1994; Wolf-Welling et al., this volume). Relatively warm Atlantic surface water reached the Iceland Sea last at 3.0 $\mathrm{Ma}$, and ice-rafting dominated the environment at Site 907 during the interval 3.0 to $1.0 \mathrm{Ma}$ (Fronval and Jansen, this volume). The Norwegian Sea was influenced by a dominant Norwegian Current until 2.75 Ma when the massive input of ice-rafted detritus started (Jansen et al., 1988; Henrich et al., 1989). In addition, Raymo et al. (1989) showed that the open North Atlantic prior to $\sim 2.75$ to $2.5 \mathrm{Ma}$ was not influ-

\section{4, Vøring Plateau}

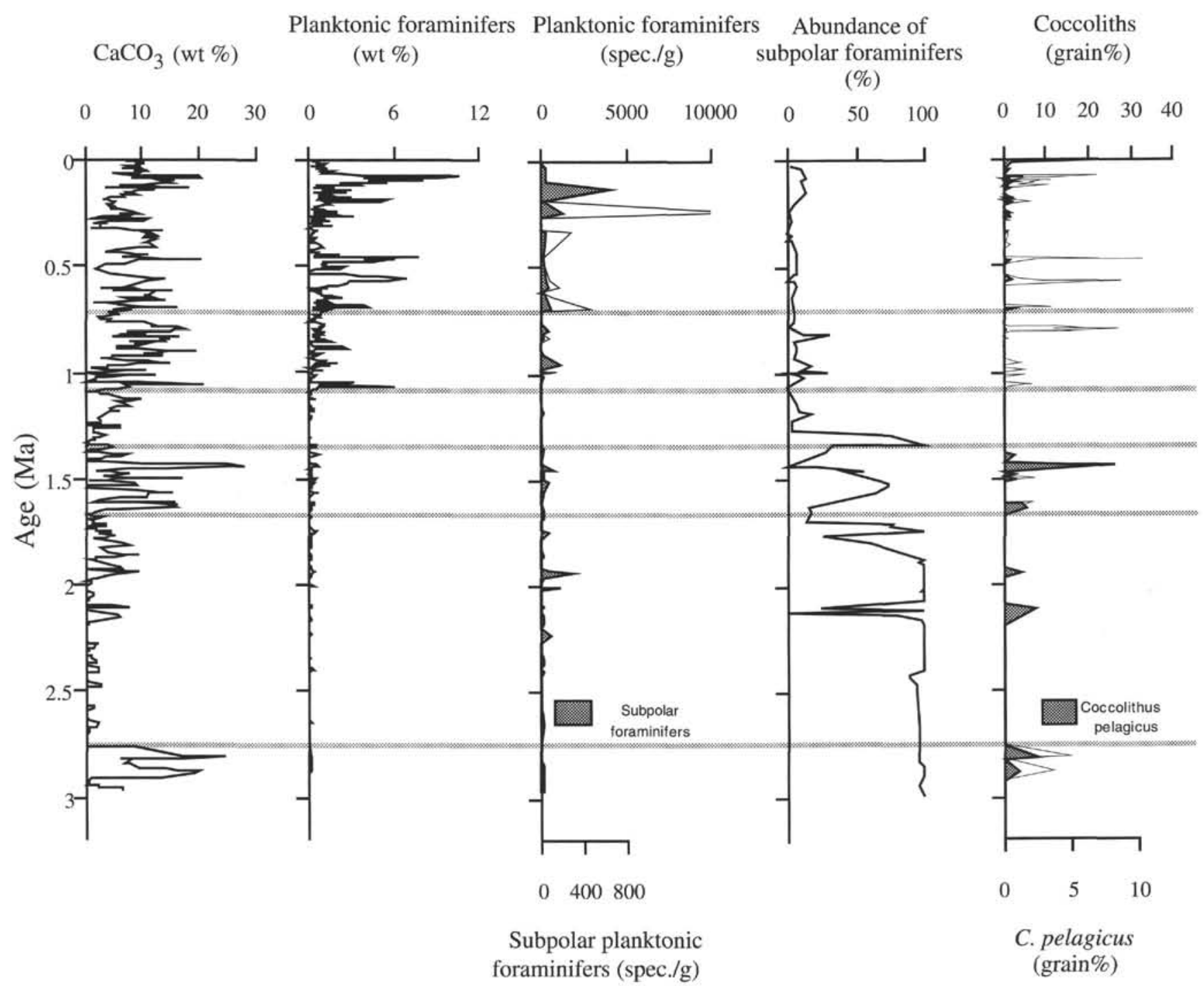

Figure 5. Smoothed carbonate record, number of planktonic foraminifers, and coccolith abundances vs. age at Site 644 . The weight percent (wt\%) data of planktonic foraminifers are taken from Henrich et al. (1989) and Wolf (1991). The stratigraphic positions of the main shifts in the paleoceanographic development (see text) are indicated by small shaded bars. 


\section{7, Island Plateau}

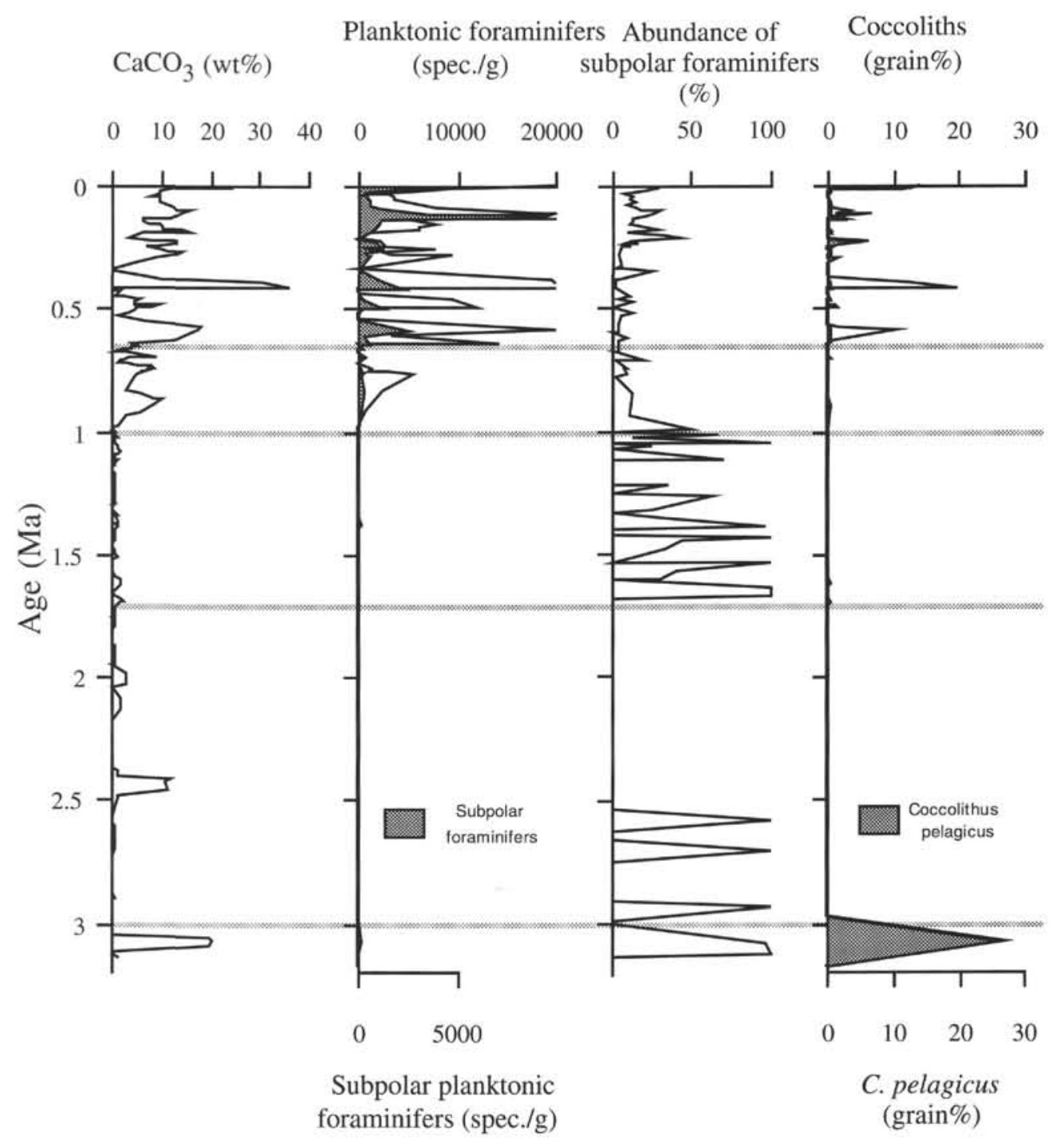

Figure 6. Smoothed carbonate record, number of planktonic foraminifers, and coccolith abundances vs. age at Site 907 . The stratigraphic positions of the main shifts in the paleoceanographic development (see text) are indicated by small shaded bars.

enced by extensive ice-rafting. Between 2.75 and $2.5 \mathrm{Ma}$, glacial episodes become progressively more severe as reflected in a more southward occurrence of IRD (Raymo, 1994).

The surface water regimes in the Iceland Sea and Fram Strait record long-lasting glacial conditions during the interval $3.0 \mathrm{Ma}$ to $1.0-0.8 \mathrm{Ma}$, whereas a stepwise development of the paleoenvironment is observed in the Norwegian Sea (Site 644) during the last 2.75 m.y. (Figs. 5-7). Intervals mostly barren in calcareous plankton indicate full-scale glacial conditions here also during most of the period until 1.65 Ma. However, Jansen et al. (1989) have already stated that the whole interval is dominated by glacials less severe than during the late Pleistocene. This is documented by small amounts of IRD and heavy oxygen isotope values in sediments of the Norwegian Sea between $2.1 \mathrm{Ma}$ and 1.3 Ma. In addition, smaller amplitude fluctuations are seen in a number of stable isotope records of the North Atlantic before 1.1 Ma (Shackleton and Hall, 1984; Jansen and Sejrup, 1986; Jansen et al., 1988). Jansen et al. (1989) suggested that a less meridional system resulted in a lack of moisture supply to the north and, thereby, reduced the ice sheets to growth less than about onehalf as large as late Pleistocene ice volumes (Raymo et al., 1989).
Short-term improvements of the cold, severe surface water conditions are indicated by slightly increased carbonate contents $(\approx 10$ $\mathrm{wt} \%$ ) as well as low abundances of planktonic foraminifers and coccolithophorids at 2.2, 2.1, and 1.95 Ma. However, surface water temperatures increased only slightly, although planktonic foraminifer assemblages are characterized by low but considerably increasing numbers of subpolar species (Figs. 5, 6). In contrast, polar species only scarcely occurred. The calcareous nannofossil assemblages are dominated by cold water-adapted Coccolithus pelagicus. This indicates at least episodic intrusions of North Atlantic surface water into the Norwegian Sea during these intervals. However, Atlantic water was concentrated to narrow intrusions along the eastern margin of the Norwegian-Greenland Sea and never reached the Iceland Sea or the Fram Strait. In addition, sediments at Site 643, which is located on the outer Vøring Plateau, are nearly barren in carbonate also and, furthermore, characterized by a low but continuous input of ice-rafted detritus throughout the entire period (Henrich and Baumann, 1994).

In the carbonate-bearing sections, carbonate tests are relatively well preserved and indicative of less-corrosive bottom water masses. The remaining records display sparse occurrences of strongly dis- 


\section{Site 909, Fram Strait}

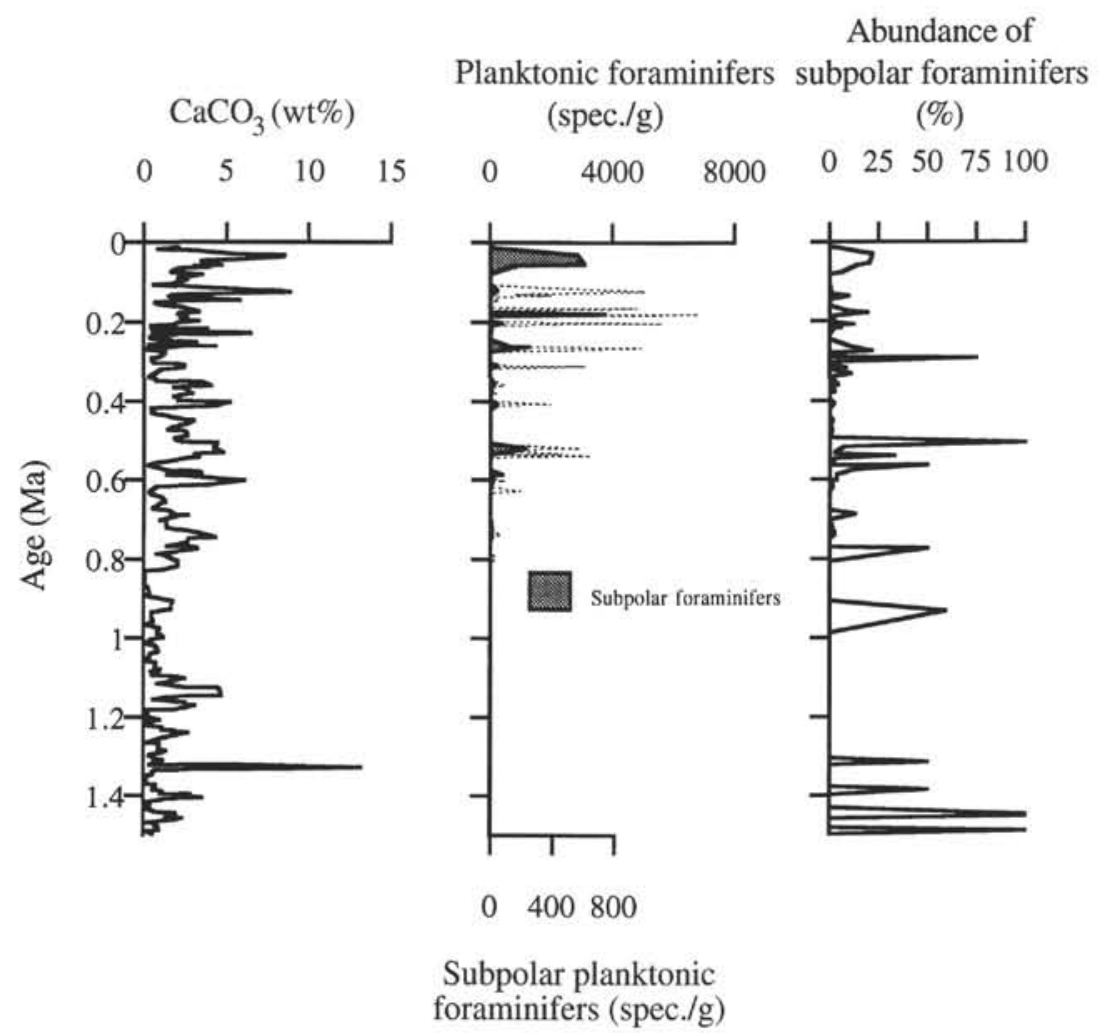

Figure 7. Smoothed carbonate records and planktonic foraminifer numbers vs. age at Site 909.

solved planktonic foraminifers and sections completely barren of planktonic foraminifers. This pattern may be associated with a weakly undersaturated water column and most probably originates from very low carbonate production in the surface water. Frequent occurrences of sponge spicules in Hole 644A throughout the period from 2.75 to $1.1 \mathrm{Ma}$ (Henrich et al., 1989) also suggest relatively well oxygenated bottom waters. In addition, heavier $\delta^{18} \mathrm{O}$ values of benthic foraminifers of the Norwegian Sea, as compared with the North Atlantic (Jansen et al., 1989), suggest a persistent deep-water exchange with the North Atlantic. Benthic foraminifer $\delta^{13} \mathrm{C}$ data from sites in the North Atlantic, Caribbean Sea, and Pacific Ocean give evidence of a relatively continuous North Atlantic Deep Water (NADW) formation throughout the last 3.0 m.y. (Raymo et al., 1992; Oppo et al., 1995). Furthermore, NADW production seemed to be more efficient before the onset of the major Northern Hemisphere glaciation, and a progressive decline in NADW production rates is linked to the cooling of sea surface temperatures at $\sim 2.75$ to $2.5 \mathrm{Ma}$ (Raymo et al., 1992). In addition, Raymo et al. $(1990,1992)$ documented an increase in the proportion of low $-\delta^{13} \mathrm{C}$, nutrient-rich waters in the deep North Atlantic that correlated with the gradual increase in glacial severity. Thus, reduced lower NADW production must have been coupled with reduced northward heat transport throughout the last 3.1 m.y. However, because NADW production rates in the NorwegianGreenland Sea are strongly dependent on the advection of salt-rich Atlantic water, the magnitude and properties of deep water formed in the Norwegian-Greenland Sea during the period 2.8 to $1.65 \mathrm{Ma}$ should be considerably different from those of the late Pleistocene. A lower quantity of possibly less dense deep water may have been formed in the eastern Norwegian Sea. This deep water mass could have contributed to the upper NADW, while the flow of lower NADW simultaneously decreased as described by Oppo et al. (1995).
High carbonate contents and relatively high abundance of planktonic organisms (Fig. 5) indicate a considerable warming of the surface water conditions in the Norwegian Sea during interglacials from 1.65 to $1.4 \mathrm{Ma}$. Large amplitude variations are due to the occurrence of climatic shifts, which are also recorded in the Labrador Sea (Baumann and Meggers, in press). The assemblages are characterized by small but significant numbers of well-preserved subpolar species during climatic optima, although cold-adapted Neogloboquadrina pachyderma $\sin$. and $C$. pelagicus dominated throughout this interval. Relatively high numbers of $C$. pelagicus at $1.45 \mathrm{Ma}$ are related to surface water conditions that are in the optimum temperature range $\left(5^{\circ} \mathrm{C}-8^{\circ} \mathrm{C}\right.$; Samtleben et al., 1995$)$ for this species. In addition, carbonate preservation considerably improved during the entire interval and, therefore, is again evident for noncorrosive bottom water. Simultaneous changes in NADW production rates may be inferred.

Generally, this pattern reflects a first pronounced increase in the meridional circulation of the northern North Atlantic, although, surface water conditions were probably colder than observed during interglacials of the late Pleistocene. Atlantic water intrusions penetrated in the Norwegian Sea only to its southeast regions (Site 644), whereas no biogenic carbonate sedimentation was furthermore evident in the Fram Strait (Site 909) and the Iceland Sea (Site 907) during this interval. An increased influx of relatively warm surface water would explain the increased carbonate accumulation at the easternmost Vøring Plateau during this period. In addition, the influx of warm water from the south provided hugh amounts of moisture for ice buildup. Jansen et al. (1988) already suspected generally increased input of ice-rafted detritus to the Norwegian Sea due to an intensified glaciation. From the IRD records a new intensification of glaciation is evident at around $1.55 \mathrm{Ma}$ (Fronval and Jansen, this volume). However, the increase in IRD fluxes recorded in the Iceland 
Plateau and Vøring Plateau data could also reflect that the melting of the ice sheets drastically increased. The importance of the access of heat to the north via the Norwegian Current both for ice buildup and melting was recently described by Hebbeln et al. (1994). In addition, a considerable improvement in carbonate preservation during this interval is also coupled to a first increased northward heat transport. This pattern may also indicate increased rates of deep-water production in the eastern Norwegian Sea that contribute to NADW.

Furthermore, the significant decrease in carbonate content as well as in the numbers of calcareous nannofossils and planktonic foraminifers at 1.4 Ma is related to another cooling event. This cold, glacialdominated period lasted until $\sim 1.1 \mathrm{Ma}$. The lack of biogenic carbonates and extensive IRD fluxes (Fronval and Jansen, this volume) are most possibly a result of the much larger expansion of the continental ice sheets onto the continental shelf than during the preceding intervals. Spiegler (1989) showed that redeposition of microfossils from the shelf areas increased during glacials after $1.2 \mathrm{Ma}$. Thus, the intensification of the meridional circulation system at $\sim 1.65$ Ma may have triggered ice-sheet growth and, thereby, increased glacial/interglacial environmental contrasts. In addition, strong carbonate dissolution on the Vøring Plateau contemporaneously occurs with low benthic foraminifer $\delta^{13} \mathrm{C}$ values in the North Atlantic (Raymo et al., 1990), which indicate a major reduction in NADW production during this interval.

\section{Paleoenvironment After the Middle Pleistocene Shift (1.1 Ma)}

The most prominent change in the numbers and composition of the calcareous plankton assemblages occurred at approximately 1.1 to $0.9 \mathrm{Ma}$. This shift is the so-called middle Pleistocene climate shift, involving a substantial change in mean state and in amplitude of climatic variations (Ruddiman et al., 1986, 1989; Ruddiman and Raymo, 1988; Berger and Jansen, 1994). This also can be seen in the present biogenic carbonate records. During interglacials of the last 1.1 m.y., calcareous nannofossils reached abundances much higher than in the late Pliocene/early Pleistocene. The number of planktonic foraminifers increased even more drastically (Figs. 2-5). These changes indicate the initiation of warmer interglacials with relatively warm surface water influx into the Norwegian-Greenland Sea and more extensive glaciations. In addition, stable isotope records indicate somewhat warmer interglacials and colder glacials characterized by larger ice sheets during the late Pleistocene than before $1.1 \mathrm{Ma}$ (Shackleton et al., 1984; Jansen and Sejrup, 1986; Jansen et al., 1988; Fronval and Jansen, this volume). A similar increase in the number of planktonic foraminifers and calcareous nannofossils at the middle Pleistocene climate shift was observed also in the northern Labrador Sea (Baumann and Meggers, in press).

During the last few years, much attention has been focused on the climatic shift at $\sim 1.0 \mathrm{Ma}$. This appears in a number of sedimentological, micropaleontological, and oxygen isotope records, which consistently show dominant power at 100-k.y. period (eccentricity) for the last $\sim 1.0 \mathrm{~m} . \mathrm{y}$. in contrast to the well-established 41-k.y. cycles before 1.0 Ma. (Shackleton and Hall, 1984; Ruddiman et al., 1989; Jansen et al., 1989; Aksu et al., 1992; Berger and Jansen, 1994; Baumann and Meggers, in press). However, these results are in contrast to the orbital insolation variations, which showed strongest power at the 41k.y. obliquity and the 23-k.y. precession periods, and comparatively only little power at the eccentricity period near 100 k.y. (Hays et al., 1976; Imbrie et al., 1992, 1993). Mechanisms other than continuous, linear responses to orbitally driven changes in the northern North Atlantic radiation budget may possibly trigger the high amplitudes and high frequencies of the late Pleistocene. Imbrie et al. (1993) proposed that, with the middle Pleistocene shift, the Northern Hemisphere ice sheets forced by external precession and obliquity exceed a critical size, and the dynamics of the ice sheets themselves trigger the mechanisms that channel energy into the 100-k.y. band.
The environmental shift in the Norwegian Sea is more gradual, rather than a single abrupt change at $\sim 1.1 \mathrm{Ma}$. A first major carbonate maximum at $1.1 \mathrm{Ma}$ at Site 644 was followed by increasingly larger amplitudes between 1.1 and $0.65 \mathrm{Ma}$. This interval is furthermore characterized by relatively low numbers of planktonic foraminifers and calcareous nannofossils, with the exception of a single peak at $0.75 \mathrm{Ma}$. In addition, a gradual increase in the influx of temperate North Atlantic surface water into the Norwegian-Greenland Sea is indicated by the presented records. In the Iceland Sea, the major increase in biogenic carbonate accumulation is seen at $\sim 1.0$ to $0.9 \mathrm{Ma}$. However, glacial conditions in the Fram Strait apparently continued at least until $\sim 0.65 \mathrm{Ma}$. The first increased numbers of planktonic foraminifers most probably mark the first major intrusion of relatively warm Atlantic water far northward. In addition, during the last 1.0 m.y. an east-west gradient in interglacial surface water temperatures existed with highest temperatures on the Vøring Plateau and coldest temperatures on the Iceland Plateau (Fronval and Jansen, this volume). Generally, a gradual transition toward larger ice volumes and longer cycles at least to $0.65 \mathrm{Ma}$ fits well with previously published records of the Norwegian Sea (Jansen et al., 1988, 1989; Henrich and Baumann, 1994). Based on North Atlantic sea-surface temperature records Ruddiman et al. (1986) also showed evidence for a more gradual attenuation of the 100-k.y. power in the climatic record since $\sim 1.0 \mathrm{Ma}$. Jansen et al. (1989) proposed that this more gradual shift was caused because the climatic system needed time to adjust the new boundary conditions, or that the changes in boundary conditions needed time to develop.

The past 0.65 m.y. reveal highest-amplitude oscillations in biogenic carbonate records. Short but warm interglacials with high biogenic carbonate accumulation and intensive deep-water formation occurred between longer glacial dominated intervals with high inputs of ice-rafted detritus. Significant Atlantic water intrusions especially during interglacials reached far up into the Fram Strait (Fig. 7). During the last $0.65 \mathrm{~m} . \mathrm{y}$., rates of ice decay are clearly faster than rates of ice growth (Ruddiman et al., 1986; Raymo, 1992). The positive feedbacks of the large ice sheets might have accelerated the destruction of ice during the late Quaternary to the point that deglaciations were more complete than during the earlier Quaternary (Ruddiman et al., 1986). Planktonic isotope data document that glacial periods became colder and more pronounced (Fronval and Jansen, this volume). Carbonate preservation improved further, both during glacials and interglacials. Overall good carbonate preservation is observed, interrupted only by short-term dissolution spikes (Henrich and Baumann, 1994). Hence, continuous formation of NADW may have occurred also during glacials, a major precondition being sufficient salt supply by temperate Atlantic surface water intrusions (e.g., Hebbeln et al., 1994). A small but persistent NADW overflow into the North Atlantic during the last glacial has been documented recently by benthic foraminifer $\delta^{13} \mathrm{C}$-gradients for the northern North Atlantic (Sarnthein et al., 1994).

\section{CONCLUSIONS}

A stepwise development of the paleoceanographical regime is evident in the Norwegian-Greenland Sea during the last 3.1 m.y.:

1. Data from Sites 907 and 644 indicate an intensification of the glaciation after $3.0 \mathrm{Ma}$ (Iceland Sea) and $2.75 \mathrm{Ma}$ (Norwegian Sea), respectively, although the preglacial pelagic fauna and flora already were limited. However, relatively high numbers of calcareous nannofossils indicate the prevailing influence of relatively warm Atlantic surface water masses before these events. In contrast, planktonic foraminifers scarcely occurred.

2. The interval from 2.75 to $1.65 \mathrm{Ma}$ is characterized by glacial conditions, low carbonate productivity of the surface waters, and, with respect to $\mathrm{CaCO}_{3}$, at most weakly undersaturated 
bottom water masses. However, weak but still recognizable northward penetrations of relatively warm Atlantic surface water reached the eastern Norwegian Sea (Site 644) several times.

3. A first considerable warming of the surface water conditions in the Norwegian Sea occurred during the interval 1.65 Ma to 1.4 Ma. Relatively high amplitudes in the biogenic calcareous records and abundant warm-adapted species indicate the presence of relatively warm surface waters during interglacials, whereas low numbers of microfossils are related to conditions dominated by sea-ice cover during glacials. In contrast, the Iceland Sea and the Fram Strait were not influenced by the relatively warm precursor of the Norwegian Current.

4. The significant decrease in the numbers of calcareous nannofossils and planktonic foraminifers at $1.4 \mathrm{Ma}$ is related to another cooling event. The period with minor carbonate accumulation lasted until $\sim 1.1 \mathrm{Ma}$ and is most possibly associated with a first major expansion of the continental ice sheets onto the continental shelf.

5. The last $1.1 \mathrm{~m} . \mathrm{y}$. are characterized by an intensification of the glacial to interglacial contrasts, reflecting a strengthening of the Norwegian Current, which is also indicated by relatively high abundances of calcareous plankton assemblages at Site 907. At Site 909 planktonic foraminifer assemblages were first recognized after $0.8 \mathrm{Ma}$.

6. The highest amplitudes in the biogenic calcareous records and lower frequency oscillations are observed during the last approximately $0.65 \mathrm{~m}$.y. Abundant warm-adapted species indicate the presence of relatively warm surface waters during peak interglacials, whereas scarce polar assemblages are related to variable conditions dominated by at least seasonal seaice cover during glacials.

7. Carbonate preservation records reveal consistent changes with the evolution of Atlantic water intrusions. The period from $\sim 2.75$ to $1.65 \mathrm{Ma}$ is characterized by widespread strong dissolution. A considerable improvement in carbonate preservation at $\sim 1.65$ to $1.4 \mathrm{Ma}$ is coupled with a first increased northward heat transport and possibly indicates increased deep-water production in the Norwegian Sea. Strong carbonate dissolution on the Vøring Plateau indicates a major reduction in deepwater production during the interval 1.4 to $1.1 \mathrm{Ma}$. With increased advection of Atlantic surface water, the magnitude of deep-water production in the Norwegian-Greenland Sea increased during the past $1.1 \mathrm{~m} . \mathrm{y}$.

\section{ACKNOWLEDGMENTS}

The assistance of the captain, crew, and technical staff of ODP Legs 104 and 151 for assistance in obtaining samples is gratefully acknowledged. Reviews by Eystein Jansen and Hans-Petter Sejrup are also greatly appreciated. We thank T. Fronval, G. Larvik, and N. Koç (all at Bergen/Norway) as well as D. Spiegler and T. Wolf-Welling (both at GEOMAR, Kiel) for sample sharing. Thanks also to Matthias von Herz, Stefan Hüneke, Anne Saschek, Jörg Brüning, and Renate Henning for technical assistance in preparation of the data sets. This work was financially supported by the Deutsche Forschungsgemeinschaft (Grant He 1671/4).

\section{REFERENCES}

Aksu, A.E., Mudie, P.J., de Vernal, A., and Gillespie, H., 1992. Ocean-atmosphere responses to climatic change in the Labrador Sea: Pleistocene plankton and pollen records. Palaeogeogr., Palaeoclimatol., Palaeoecol., 92:124-137.

Backman, J., and Pestiaux, P., 1987. Pliocene Discoaster abundance variations, Deep Sea Drilling Project Site 606: biochronology and paleoenvi- ronmental implications. In Ruddiman, W.F., Kidd, R.B., Thomas, E., et al., Init. Repts. DSDP, 94 (Pt. 2): Washington (U.S. Govt. Printing Office), 903-910.

Backman, J., Pestiaux, P., Zimmerman, H., and Hermelin, J.O.R., 1986. Palaeoclimatic and palaeoceanographic development in the Pliocene North Atlantic: Discoaster accumulation and coarse fraction data. In Summerhayes, C.P., and Shackleton, N.J. (Eds.), North Atlantic Palaeoceanography, Geol. Soc. Spec. Publ. London, 21:231-241.

Baumann, K.-H., 1990. Veränderlichkeit der Coccolithophoridenflora des Europäischen Nordmeeres im Jungquartär. Ber. Sonderforschungsber. $313,22: 1-146$.

Baumann, K.-H., Lackschewitz, K.S., Erlenkeuser, H., Henrich, R., and Jünger, B., 1993. Late Quaternary calcium carbonate sedimentation and terrigenous input along the east Greenland continental margin. Mar. Geol., 114:13-36.

Baumann, K.-H., Lackschewitz, K.S., Mangerud, J., Spielhagen, R.F., WolfWelling, T.C.W., Henrich, R., and Kassens, H., 1995. Reflection of Scandinavian ice sheet fluctuations in Norwegian Sea sediments during the past 150,000 years. Quat. Res., 43:185-197.

Baumann, K.H., and Meggers, H., in press. Palaeoceanographic changes in the Labrador Sea during the past $3.0 \mathrm{My}$ : evidence from calcareous plankton records. In Whatley, R., and Moguilevsky, A. (Eds.), Microfossils and Oceanic Environments: Univ. of Wales (Aberystwyth Press).

Bé, A.W.H., 1977. An ecological, zoogeographic and taxonomic review of Recent planktonic foraminifera. In Ramsay, A.T.S. (Ed.), Oceanic Micropaleontology (Vol. 1): London (Acad. Press), 1-100.

Berger, W.H., and Jansen, E., 1994. Mid-Pleistocene climate shift: the Nansen connection. In Johannessen, O.M., Muensch, R.D., and Overland, J.E. (Eds.), The Role of the Polar Oceans in Shaping the Global Environment. Geophys. Monogr., Am. Geophys. Union, 84:295-311.

Bohrmann, G., Henrich, R., and Thiede, J., 1990. Miocene to Quaternary paleoceanography in the northern North Atlantic: variability in changes in carbonate and biogenic opal accumulation. In Bleil, U., and Thiede, J. (Eds.), Geological History of the Polar Oceans: Arctic versus Antarctic. NATO ASI Ser. C, 647-675.

Braarud, T., 1979. The temperature range of the non-motile stage of Coccolithus pelagicus in the North Atlantic region. Br. Phycol. J., 14:349-352.

Carstens, J., and Wefer, G., 1992. Recent distribution of planktonic foraminifera in the Nansen Basin, Arctic Ocean. Deep Sea Res. Part A, 39:507524.

Dowsett, H.J., and Poore, R.Z., 1990. A new planktic foraminifer transfer function for estimating Pliocene-Holocene paleoceanographic conditions in the North Atlantic. Mar. Micropaleontol., 16:1-23.

Håkansson, E., and Stemmerik, L., 1984. Wandel Sea Basin: The North Greenland equivalent to Svalbard and the Barents Shelf. In Spencer, A.M., et al. (Eds.), Petroleum Geology of the North European Margin. Norw. Petrol. Soc., 97-107.

Hays, J.D., Imbrie, J., and Shackleton, N.J., 1976. Variations in the Earth's orbit: pacemaker of the ice ages. Science, 194:1121-1132.

Hebbeln, D., Dokken, T., Andersen, E.S., Hald, M., and Elverhøi, A., 1994. Moister supply to northern ice-sheet growth during the Last Glacial Maximum. Nature, 350:357-360.

Hebbeln, D., and Wefer, G., 1991. Effects of ice coverage and ice-rafted material on sedimentation in the Fram Strait. Nature, 350:409-411.

Henrich, R., 1989. Glacial/interglacial cycles in the Norwegian Sea: sedimentology, paleoceanography, and evolution of late Pliocene to Quaternary Northern Hemisphere climate. In Eldholm, O., Thiede, J., Taylor, E., et al., Proc. ODP, Sci. Results, 104: College Station, TX (Ocean Drilling Program), 189-232.

Henrich, R., and Baumann, K.H. 1994. Evolution of the Norwegian Current and the Scandinavian Ice Sheets during the past 2.6 m.y.: evidence from ODP Leg 104 biogenic carbonate and terrigenous records. Palaeogeogr., Palaeoclimatol., Palaeoecol., 108:75-94.

Henrich, R., Wolf, T., Bohrmann, G., and Thiede, J., 1989. Cenozoic paleoclimatic and paleoceanographic changes in the Northern Hemisphere revealed by variability of coarse-fraction composition in sediments from the Vøring Plateau-ODP Leg 104 drill sites. In Eldholm, O., Thiede, J., Taylor, E., et al., Proc. ODP, Sci. Results, 104: College Station, TX (Ocean Drilling Program), 75-188.

Imbrie, J., Berger, A., Boyle, E., Clemens, S., Duffy, A., Howard, W., Kukla, G., Kutzbach, J., Martinson, D., McIntyre, A., Mix, A., Molfino, B., Morley, J., Peterson, L., Pisias, N., Prell, W., Raymo, M., Shackleton, N., and Toggweiler, J., 1993. On the structure and origin of major glaciation cycles, 2 . The 100,000-year cycle. Paleoceanography, 8:699-735. 
Imbrie, J., Boyle, E.A., Clemens, S.C., Duffy. A., Howard, W.R., Kukla, G., Kutzbach, J., Martinson, D.G., McIntyre, A., Mix, A.C., Molfino, B., Morley, J.J., Peterson, L.C., Pisias, N.G., Prell, W.L., Raymo, M.E., Shackleton, N.J., and Toggweiler, J.R., 1992. On the structure and origin of major glaciation cycles, 1. Linear responses to Milankovitch forcing. Paleoceanography, 7:701-738.

Jansen, E., Bleil, U., Henrich, R., Kringstad, L., and Slettemark, B., 1988. Paleoenvironmental changes in the Norwegian Sea and Northeast Atlantic during the last 2.8 m.y.: Deep Sea Drilling Project/Ocean Drilling Program Sites 610, 642, 643, and 644. Paleoceanography, 3:563-581.

Jansen, E., and Sejrup, H.P., 1986. Stable isotope stratigraphy and aminoacid epimerization for the last 2.4 My at Site 610, Holes 610 and 610A. In Ruddiman, W.F., Kidd, R.B., Thomas, E., et al., Init. Repts. DSDP, 94: Washington (U.S. Govt. Printing Office), 879-888.

Jansen, E., and Sjøholm, J., 1991. Reconstruction of glaciation over the past $6 \mathrm{Myr}$ from ice-borne deposits in the Norwegian Sea. Nature, 349:600603.

Jansen, E., Sjøholm, J., Bleil, U., and Erichsen, J.A., 1990. Neogene and Pleistocene glaciations in the northern hemisphere and late MiocenePliocene global ice volume fluctuations: evidence from the Norwegian Sea. In Bleil, U., and Thiede, J. (Eds.), Geological History of the Polar Oceans: Arctic Versus Antarctic: Dordrecht (Kluwer), 677-705.

Jansen, E., Slettemark, B., Bleil, U., Henrich, R., Kringstad, L., and Rolfsen, S., 1989. Oxygen and carbon isotope stratigraphy and magnetostratigraphy of the last $2.8 \mathrm{Ma}$ : paleoclimatic comparisons between the Norwegian Sea and the North Atlantic. In Eldholm, O., Thiede, J., Taylor, E., et al., Proc. ODP, Sci. Results, 104: College Station, TX (Ocean Drilling Program), 255-269.

Johannessen, O.M., 1986. Brief overview of the physical oceanography. In Hurdle, B.G. (Ed.), The Nordic Seas: New York (Springer-Verlag), 103127.

Keigwin, L.D., 1987. Pliocene stable-isotope record of Deep Sea Drilling Project Site 606: sequential events of ${ }^{18} \mathrm{O}$ enrichment beginning at 3.1 Ma. In Ruddiman, W.F., Kidd, R.B., Thomas, E., et al., Init. Repts. DSDP, 94 (Pt. 2): Washington (U.S. Govt. Printing Office), 911-920.

Kellogg, T.B., 1975. Late Quaternary climatic changes in the NorwegianGreenland Sea. In Bowling, S.A., and Weller, G. (Eds.), Climate of the Arctic: Fairbanks (Univ. Alaska Press), 3-36.

1976. Paleoclimatology and paleoceanography of the Norwegian and Greenland Seas: the last 450,000 years. Mar. Micropaleontol., $2: 235-249$.

Korstgaard, J.A., and Nielsen, O.B., 1989. Provenance of dropstones in Baffin Bay and Labrador Sea, Leg 105. In Srivastava, S.P., Arthur, M.A., Clement, B., et al., Proc. ODP, Sci. Results, 105: College Station, TX (Ocean Drilling Program), 65-69.

Krissek, L.A., 1989. Late Cenozoic records of ice-rafting at ODP Sites 642, 643, and 644, Norwegian Sea: onset, chronology, and characteristics of glacial/interglacial fluctuations. In Eldholm, O., Thiede, J., Taylor, E., et al., Proc. ODP, Sci. Results, 104: College Station, TX (Ocean Drilling Program), 61-74.

Larsen, H.C., Saunders, A.D., Clift, P.D., Beget, J., Wei, W., Spezzaferri, S., and the ODP Leg 152 Scientific Party, 1994. Seven million years of glaciation in Greenland. Science, 264:952-955.

Loubere, P., and Moss, K., 1986. Late Pliocene climatic change and the onset of Northern Hemisphere glaciation as recorded in the northeast Atlantic Ocean. Geol. Soc. Am. Bull., 97:818-828.

Myhre, A.M., Thiede, J., Firth, J.V., et al., 1995. Proc. ODP, Init. Repts., 151: College Station, TX (Ocean Drilling Program).

Oppo, D.W., Raymo, M.E., Lohmann, G.P., Mix, A.C., Wright, J.D., and Prell, W.L., 1995. $\delta^{13} \mathrm{C}$ record of upper North Atlantic deep water during the past 2.6 m.y. Paleoceanography, 10:373-394.

Prell, W.L., 1984. Covariance patterns of foraminiferal $\delta^{18} \mathrm{O}$ : an evaluation of Pliocene ice volume changes near 3.2 million years ago. Science, 226:692-694.

Raymo, M.E., 1992. Global climate change: a three million year perspective. In Kukla, G.J., and Went, E. (Eds.), Start of a Glacial. NATO ASI Ser. I: Berlin (Springer-Verlag), 3:207-223.

1994. The initiation of Northern Hemisphere glaciation. Annu. Rev. Earth Planet. Sci., 22:353-383.
Raymo, M.E., Hodell, D., and Jansen, E., 1992. Response of deep ocean circulation to initiation of Northern Hemisphere glaciation (3-2 Ma). Paleoceanography, 7:645-672.

Raymo, M.E., Ruddiman, W.F., Backman, J., Clement, B.M., and Martinson, D.G., 1989. Late Pliocene variation in Northern Hemisphere ice sheets and North Atlantic deep water circulation. Paleoceanography, 4:413446.

Raymo, M.E., Ruddiman, W.F., and Clement, B.M., 1987. Pliocene-Pleistocene paleoceanography of the North Atlantic at DSDP Site 609. In Ruddiman, W.F., Kidd, R.B., Thomas, E., et al., Init. Repts. DSDP, 94 (Pt. 2): Washington (U.S. Govt. Printing Office), 895-901.

Raymo, M.E., Ruddiman, W.F., Shackleton, N.J., and Oppo, D.W., 1990. Evolution of Atlantic-Pacific $\delta^{13} \mathrm{C}$ gradients over the last 2.5 m.y. Earth Planet. Sci. Lett., 97:353-368.

Ruddiman, W.F., McIntyre, A., and Raymo, M., 1986. Matuyama 41,000year cycles: North Atlantic Ocean and northern hemisphere ice sheets. Earth Planet. Sci. Lett., 80:117-129.

Ruddiman, W.F., and Raymo, M.E., 1988. Northern hemisphere climatic regimes during the past $3 \mathrm{Ma}$ : possible tectonic connections, Philos. Trans. R. Soc. London B, 318:411-430.

Ruddiman, W.F., Raymo, M.E., Martinson, D.G., Clement, B.M., and Backman, J., 1989. Pleistocene evolution: Northern Hemisphere ice sheets and North Atlantic Ocean. Paleoceanography, 4:353-412.

Samtleben, C., Baumann, K.-H., and Schröder, A., 1995. Distribution, composition and seasonal variation of coccolithophore communities in the northern North Atlantic. In Flores, J.A., and Sierro, F.J. (Eds.), Proc. 5th INA Conf., Univ. de Salamanca, 219-235.

Samtleben, C., and Schröder, A., 1992. Living coccolithophore communities in the Norwegian-Greenland Sea and their record in sediments. Mar. Micropaleontol., 19:333-354.

Sarnthein, M., Winn, K., Jung, S., Duplessy, J.-C., Labeyrie, L., Erlenkeuser, H., and Ganssen, G., 1994. Changes in East Atlantic deep-water circulation over the last 30,000 years: eight-time-slice reconstructions. Paleoceanography, 9:209-267.

Schaeffer, R., and Spiegler, D., 1986. Neogene Kälteeinbrüche und Vereisungsphasen im Nordatlantik. Z. Disch. Geol. Ges., 137:537-552.

Shackleton, N.J., Backman, J., Zimmerman, H., Kent, D.V., Hall, M.A., Roberts, D.G., Schnitker, D., Baldauf, J.G., Desprairies, A., Homrighausen, R., Huddlestun, P., Keene, J.B., Kaltenback, A.J., Krumsiek, K.A.O., Morton, A.C., Murray, J.W., and Westberg-Smith, J., 1984. Oxygen isotope calibration of the onset of ice-rafting and history of glaciation in the North Atlantic region. Nature, 307:620-623.

Shackleton, N.J., Crowhurst, S., Hagelberg, T., Pisias, N.G., and Schneider, D.A., 1995. A new late Neogene time scale: application to Leg 138 sites. In Pisias, N.G., Mayer, L.A., Janecek, T.R., Palmer-Julson, A., and van Andel, T.H. (Eds.), Proc. ODP, Sci. Results, 138: College Station, TX (Ocean Drilling Program), 73-101.

Shackleton, N.J., and Hall, M.A., 1984. Oxygen and carbon isotope stratigraphy of Deep Sea Drilling Project Hole 552A: Plio-Pleistocene glacial history. In Roberts, D.G., Schnitker, D., et al., Init. Repts. DSDP, 81: Washington (U.S. Govt. Printing Office), 599-609.

Spiegler, D., 1989. Ice-rafted Cretaceous and Tertiary fossils in PleistocenePliocene sediments, ODP Leg 104, Norwegian Sea. In Eldholm, O., Thiede, J., Taylor, E., et al., Proc. ODP, Sci. Results, 104: College Station, TX (Ocean Drilling Program), 739-744.

Swift, J.H., 1986. The Arctic waters. In Hurdle, B.G. (Ed.), The Nordic Seas: Berlin (Springer-Verlag), 129-153.

Wolf, T.C.W., 1991. Paläo-ozeanographisch-klimatische Entwicklung des nördlichen Nordatlantiks seit dem späten Neogen: (ODP Legs 105 und 104, DSDP Leg 81). GEOMAR Rep., 5:1-89.

Wolf, T.C.W., and Thiede, J., 1991. History of terrigenous sedimentation during the past 10 m.y. in the North Atlantic (ODP Legs 104 and 105 and DSDP Leg 94). Mar. Geol., 101:83-102.

Date of initial receipt: 1 July 1995

Date of acceptance: 5 December 1995

Ms 151SR-138 
APPENDIX

Table 1.1. Bulk carbonate content of Site 644. Previously published $\mathrm{CaCO}_{3}$ data from the uppermost 250.0 mbsf of this site (Henrich et al., 1989) are not listed.

\begin{tabular}{|c|c|c|}
\hline $\begin{array}{l}\text { Core, section, } \\
\text { interval }(\mathrm{cm})\end{array}$ & $\begin{array}{l}\text { Depth } \\
\text { (mbsf) }\end{array}$ & $\begin{array}{l}\mathrm{CaCO}_{3} \\
\text { (wt\%) }\end{array}$ \\
\hline \multicolumn{3}{|l|}{ 104-644A- } \\
\hline $\mathrm{IH}-1,33$ & 0.33 & 8.11 \\
\hline $1 \mathrm{H}-3,33$ & 3.33 & 9.84 \\
\hline $1 \mathrm{H}-5,96$ & 6.96 & 7.06 \\
\hline $1 \mathrm{H}-6,69$ & 8.19 & 11.34 \\
\hline $2 \mathrm{H}-1,3$ & 9.23 & 9.42 \\
\hline $2 \mathrm{H}-1,93$ & 10.13 & 7.37 \\
\hline $2 \mathrm{H}-5,36$ & 15.56 & 11.33 \\
\hline $3 \mathrm{H}-1,32$ & 16.52 & 11.83 \\
\hline $3 \mathrm{H}-2,2$ & 17.72 & 7.92 \\
\hline $3 \mathrm{H}-5,73$ & 22.93 & 6.31 \\
\hline $3 \mathrm{H}-6,37$ & 24.07 & 7.71 \\
\hline $4 \mathrm{H}-4,96$ & 31.16 & 3.53 \\
\hline $4 \mathrm{H}-4,131$ & 31.51 & 1.99 \\
\hline $4 \mathrm{H}-6,2$ & 33.22 & 7.39 \\
\hline $5 \mathrm{H}-4,118$ & 40.88 & 10.25 \\
\hline $5 \mathrm{H}-5,68$ & 41.88 & 9.95 \\
\hline $6 \mathrm{H}-1,33$ & 45.03 & 15.51 \\
\hline $6 \mathrm{H}-4,9$ & 49.29 & 13.60 \\
\hline $6 \mathrm{H}-4,36$ & 49.56 & 24.41 \\
\hline $6 \mathrm{H}-6,73$ & 52.93 & 11.92 \\
\hline $7 \mathrm{H}-2,20$ & 55.40 & 6.86 \\
\hline $7 \mathrm{H}-4,55$ & 59.25 & 12.70 \\
\hline $7 \mathrm{H}-4,69$ & 59.39 & 14.14 \\
\hline $8 \mathrm{H}-1,11$ & 63.81 & 10.73 \\
\hline $8 \mathrm{H}-4,34$ & 68.54 & 15.61 \\
\hline $8 \mathrm{H}-4,52$ & 68.72 & 13.20 \\
\hline $9 \mathrm{H}-1,48$ & 73.68 & 14.29 \\
\hline $9 \mathrm{H}-1,69$ & 73.89 & 16.71 \\
\hline $9 \mathrm{H}-\mathrm{CC}, 12$ & 82.32 & 13.72 \\
\hline $10 \mathrm{H}-2,34$ & 84.54 & 9.17 \\
\hline $10 \mathrm{H}-2,67$ & 84.87 & 17.47 \\
\hline $10 \mathrm{H}-2,97$ & 85.17 & 14.32 \\
\hline $10 \mathrm{H}-2,130$ & 85.50 & 19.72 \\
\hline $10 \mathrm{H}-3,69$ & 86.39 & 15.94 \\
\hline $10 \mathrm{H}-3,92$ & 86.62 & 8.36 \\
\hline $10 \mathrm{H}-4,109$ & 88.29 & 9.30 \\
\hline $10 \mathrm{H}-4,135$ & 88.55 & 14.60 \\
\hline $10 \mathrm{H}-5,8$ & 88.78 & 10.58 \\
\hline $10 \mathrm{H}-5,29$ & 88.99 & 14.51 \\
\hline $10 \mathrm{H}-5,68$ & 89.38 & 13.06 \\
\hline $10 \mathrm{H}-5,135$ & 90.05 & 13.85 \\
\hline $10 \mathrm{H}-6,11$ & 90.31 & 10.86 \\
\hline $10 \mathrm{H}-\mathrm{CC}, 20$ & 91.90 & 5.80 \\
\hline $11 \mathrm{H}-1,11$ & 92.31 & 9.07 \\
\hline $11 \mathrm{H}-3,49$ & 95.69 & 18.95 \\
\hline $11 \mathrm{H}-3,69$ & 95.89 & 18.04 \\
\hline $11 \mathrm{H}-3,129$ & 96.49 & 16.29 \\
\hline $11 \mathrm{H}-4,10$ & 96.80 & 3.07 \\
\hline $11 \mathrm{H}-4,88$ & 97.58 & 12.54 \\
\hline $11 \mathrm{H}-4,135$ & 98.07 & 7.40 \\
\hline $11 \mathrm{H}-6,135$ & 101.05 & 15.50 \\
\hline $11 \mathrm{H}-7,10$ & 101.30 & 13.45 \\
\hline
\end{tabular}

\begin{tabular}{|c|c|c|}
\hline $\begin{array}{l}\text { Core, section, } \\
\text { interval }(\mathrm{cm})\end{array}$ & $\begin{array}{l}\text { Depth } \\
\text { (mbsf) }\end{array}$ & $\begin{array}{l}\mathrm{CaCO}_{3} \\
\text { (wts) }\end{array}$ \\
\hline $12 \mathrm{H}-2,110$ & 104.30 & 11.01 \\
\hline $12 \mathrm{H}-2,127$ & 104.47 & 8.27 \\
\hline $12 \mathrm{H}-4,52$ & 106.72 & 1.75 \\
\hline $12 \mathrm{H}-4,73$ & 106.93 & 14.79 \\
\hline $12 \mathrm{H}-6,111$ & 110.31 & 21.32 \\
\hline $12 \mathrm{H}-6,137$ & 110.57 & 11.28 \\
\hline $13 \mathrm{H}-3,83$ & 115.03 & 1.01 \\
\hline $13 \mathrm{H}-4,87$ & 116.57 & 13.98 \\
\hline $14 \mathrm{H}-2,56$ & 122.76 & 1.05 \\
\hline $14 \mathrm{H}-3,113$ & 124.83 & 0.43 \\
\hline $15 \mathrm{H}-1,11$ & 130.31 & 0.09 \\
\hline $15 \mathrm{H}-5,42$ & 136.62 & 7.81 \\
\hline $15 \mathrm{H}-6,10$ & 137.80 & 3.60 \\
\hline $16 \mathrm{H}-1,62$ & 140.32 & 21.77 \\
\hline $16 \mathrm{H}-1,82$ & 140.52 & 24.49 \\
\hline $16 \mathrm{H}-1,84$ & 140.54 & 25.69 \\
\hline $16 \mathrm{H}-3,19$ & 142.89 & 0.99 \\
\hline $16 \mathrm{H}-3,82$ & 143.52 & 11.78 \\
\hline $16 \mathrm{H}-4,42$ & 144.64 & 1.82 \\
\hline $16 \mathrm{H}-4,62$ & 144.82 & 16.50 \\
\hline $16 \mathrm{H}-4,82$ & 145.02 & 16.45 \\
\hline $16 \mathrm{H}-5,42$ & 146.12 & 1.03 \\
\hline $16 \mathrm{H}-5,62$ & 146.32 & 0.59 \\
\hline $16 \mathrm{H}-5,82$ & 146.52 & 0.10 \\
\hline $17 \mathrm{H}-1,13$ & 149.33 & 0.00 \\
\hline $17 \mathrm{H}-4,13$ & 153.83 & 2.39 \\
\hline $17 \mathrm{H}-4,62$ & 154.32 & 23.74 \\
\hline $17 \mathrm{H}-4,82$ & 154.52 & 10.99 \\
\hline $17 \mathrm{H}-5,42$ & 155.62 & 6.85 \\
\hline $17 \mathrm{H}-6,13$ & 156.83 & 2.14 \\
\hline $17 \mathrm{H}-6,86$ & 157.56 & 0.00 \\
\hline $17 \mathrm{H}-7,26$ & 158.06 & 2.57 \\
\hline $17 \mathrm{H}-\mathrm{CC}, 10$ & 158.60 & 0.50 \\
\hline $18 \mathrm{H}-1,82$ & 159.52 & 0.60 \\
\hline $18 \mathrm{H}-3,82$ & 162.52 & 1.24 \\
\hline $18 \mathrm{H}-4,22$ & 163.42 & 1.85 \\
\hline $18 \mathrm{H}-4,82$ & 164.02 & 0.42 \\
\hline $18 \mathrm{H}-5,82$ & 165.52 & 0.00 \\
\hline $18 \mathrm{H}-6,22$ & 166.42 & 0.13 \\
\hline $19 \mathrm{H}-1,95$ & 169.15 & 1.87 \\
\hline $19 \mathrm{H}-1,145$ & 169.65 & 16.25 \\
\hline $20 \mathrm{H}-2,22$ & 179.42 & 0.54 \\
\hline $22 \mathrm{H}-4,82$ & 192.12 & 10.42 \\
\hline $23 \mathrm{H}-1,60$ & 194.70 & 9.24 \\
\hline $24 \mathrm{H}-2,82$ & 203.42 & 2.79 \\
\hline $28 \mathrm{H}-1,62$ & 216.72 & 1.89 \\
\hline $32 \mathrm{H}-2,62$ & 240.22 & 25.92 \\
\hline $32 \mathrm{H}-2,82$ & 240.42 & 22.71 \\
\hline $32 \mathrm{H}-2,106$ & 240.66 & 4.55 \\
\hline $32 \mathrm{H}-4,82$ & 243,42 & 10.44 \\
\hline $34 \mathrm{H}-1,82$ & 246.82 & 13.45 \\
\hline $34 \mathrm{H}-5,82$ & 251.32 & 0.05 \\
\hline
\end{tabular}


Table 1.2. Bulk carbonate content and SEM dissolution indices of Site 907.

\begin{tabular}{|c|c|c|c|c|c|c|c|c|c|c|c|}
\hline $\begin{array}{l}\text { Core, section, } \\
\text { interval }(\mathrm{cm})\end{array}$ & $\begin{array}{l}\text { Depth } \\
\text { (mbsf) }\end{array}$ & $\begin{array}{l}\mathrm{CaCO}_{3} \\
(\mathrm{wt} \%)\end{array}$ & $\begin{array}{l}\text { Dissolution } \\
\text { index }\end{array}$ & $\begin{array}{l}\text { Core, section, } \\
\text { interval }(\mathrm{cm})\end{array}$ & $\begin{array}{l}\text { Depth } \\
\text { (mbsf) }\end{array}$ & $\begin{array}{l}\mathrm{CaCO}_{3} \\
(\mathrm{wt} \%)\end{array}$ & $\begin{array}{l}\text { Dissolution } \\
\text { index }\end{array}$ & $\begin{array}{l}\text { Core, section, } \\
\text { interval }(\mathrm{cm})\end{array}$ & $\begin{array}{l}\text { Depth } \\
\text { (mbsf) }\end{array}$ & $\begin{array}{l}\mathrm{CaCO}_{3} \\
(\mathrm{wt} \%)\end{array}$ & $\begin{array}{l}\text { Dissolution } \\
\text { index }\end{array}$ \\
\hline $151-907 \mathrm{~A}-$ & & & & $2 \mathrm{H}-3,44$ & 10.74 & & 1.65 & $3 \mathrm{H}-7,10$ & 25.90 & 0.08 & 2.21 \\
\hline $1 \mathrm{H}-1,8$ & 0.08 & 48.86 & 1.06 & $2 \mathrm{H}-3,54$ & 10.84 & 9.38 & & $3 \mathrm{H}-7,45$ & 26.25 & 2.01 & \\
\hline $1 \mathrm{H}-1,24$ & 0.24 & & 1.03 & $2 \mathrm{H}-3,93$ & 11.23 & 2.35 & & $4 \mathrm{H}-1,15$ & 26.45 & 0.00 & \\
\hline $\mathrm{IH}-1,35$ & 0.35 & 8.39 & & $2 \mathrm{H}-3,108$ & 11.38 & 7.83 & 3.00 & $4 \mathrm{H}-1,60$ & 26.90 & 0.53 & \\
\hline $1 \mathrm{H}-\mathrm{I}, 44$ & 0.44 & & 2.36 & $2 \mathrm{H}-3,116$ & 11.46 & & 3.24 & $4 \mathrm{H}-1,78$ & 27.08 & 0.17 & 2.11 \\
\hline $1 \mathrm{H}-1,56$ & 0.56 & 12.68 & & $2 \mathrm{H}-3,135$ & 11.65 & 2.81 & & $4 \mathrm{H}-1,95$ & 27.25 & 1.08 & \\
\hline $1 \mathrm{H}-1,65$ & 0.65 & & 2.17 & $2 \mathrm{H}-4,5$ & 11.85 & 4.28 & & $4 \mathrm{H}-1,123$ & 27.53 & 0.17 & \\
\hline $\mathrm{IH}-1,71$ & 0.71 & 7.41 & 1.25 & $2 \mathrm{H}-4,3 \mathrm{I}$ & 12.11 & 4.26 & 2.90 & $4 \mathrm{H}-2,10$ & 27.90 & 0.13 & 3.00 \\
\hline $1 \mathrm{H}-1,94$ & 0.94 & 8.00 & & $2 \mathrm{H}-4,58$ & 12.38 & 1.07 & & $4 \mathrm{H}-2,45$ & 28.25 & 0.01 & \\
\hline $1 \mathrm{H}-1,112$ & 1.12 & & 0.94 & $2 \mathrm{H}-4,65$ & 12.45 & 0.75 & & $4 \mathrm{H}-2,84$ & 28.64 & 2.11 & \\
\hline $1 \mathrm{H}-1,135$ & 1.35 & 12.85 & & $2 \mathrm{H}-4,80$ & 12.60 & 0.25 & 3.39 & $4 \mathrm{H}-2,120$ & 29.00 & 0.18 & \\
\hline $1 \mathrm{H}-1,143$ & 1.43 & & 1.97 & $2 \mathrm{H}-4,105$ & 12.85 & 2.85 & & $4 \mathrm{H}-2,144$ & 29.24 & 0.34 & \\
\hline $1 \mathrm{H}-2,11$ & 1.61 & 9.25 & 1.00 & $2 \mathrm{H}-4,115$ & 12.95 & & 3.14 & $4 \mathrm{H}-3,35$ & 29.65 & 0.00 & \\
\hline $1 \mathrm{H}-2,25$ & 1.75 & 15.62 & & $2 \mathrm{H}-4,125$ & 13.05 & 2.94 & & $4 \mathrm{H}-3,48$ & 29.78 & 0.19 & 2.00 \\
\hline $1 \mathrm{H}-2,35$ & 1.85 & 17.59 & & $2 \mathrm{H}-5,15$ & 13.45 & 10.87 & & $4 \mathrm{H}-3,75$ & 30.05 & 0.00 & \\
\hline $1 \mathrm{H}-2,45$ & 1.95 & & 1.44 & $2 \mathrm{H}-5,36$ & 13.66 & 3.33 & & $4 \mathrm{H}-4,85$ & 31.65 & 0.54 & \\
\hline $1 \mathrm{H}-2,55$ & 2.05 & & 1.35 & $2 \mathrm{H}-5,40$ & 13.70 & 2.67 & 2.91 & $4 \mathrm{H}-4,100$ & 31.80 & 0.08 & 4.00 \\
\hline $1 \mathrm{H}-2,65$ & 2.15 & 9.72 & & $2 \mathrm{H}-5,47$ & 13.77 & & 2.07 & $4 \mathrm{H}-4,135$ & 32.15 & 0.03 & \\
\hline $1 \mathrm{H}-2,75$ & 2.25 & & 1.84 & $2 \mathrm{H}-5,55$ & 13.85 & 3.75 & & $4 \mathrm{H}-5,5$ & 32.35 & 1.95 & \\
\hline $1 \mathrm{H}-2,85$ & 2.35 & 8.79 & & $2 \mathrm{H}-5,85$ & 14.15 & 0.22 & & $4 \mathrm{H}-5,17$ & 32.47 & 2.32 & \\
\hline $1 \mathrm{H}-2,110$ & 2.60 & 9.41 & 1.87 & $2 \mathrm{H}-5,110$ & 14.40 & 1.99 & 2.47 & $4 \mathrm{H}-5,25$ & 32.55 & 3.06 & \\
\hline $1 \mathrm{H}-2,127$ & 2.77 & 12.02 & & $2 \mathrm{H}-5,115$ & 14.45 & & 3.22 & $4 \mathrm{H}-5,55$ & 32.85 & 0.27 & \\
\hline $1 \mathrm{H}-2,135$ & 2.85 & & 1.91 & $2 \mathrm{H}-5,135$ & 14.65 & 5.51 & & $4 \mathrm{H}-5,85$ & 33.15 & 0.90 & \\
\hline $1 \mathrm{H}-2,143$ & 2.93 & 7.83 & & $2 \mathrm{H}-6,5$ & 14.85 & 8.24 & & $4 \mathrm{H}-5,110$ & 33.40 & 0.37 & \\
\hline $1 \mathrm{H}-3,5$ & 3.05 & 10.38 & 1.00 & $2 \mathrm{H}-6,23$ & 15.03 & 9.14 & & $4 \mathrm{H}-3,110$ & 30.40 & 0.00 & 2.39 \\
\hline $1 \mathrm{H}-3,16$ & 3.16 & 12.92 & & $2 \mathrm{H}-6,30$ & 15.10 & 8.41 & 2.00 & $4 \mathrm{H}-3,145$ & 30.75 & 1.28 & \\
\hline $1 \mathrm{H}-3,26$ & 3.26 & 15.08 & & $2 \mathrm{H}-6,47$ & 15.27 & 5.82 & 1.97 & $4 \mathrm{H}-4,15$ & 30.95 & 4.12 & \\
\hline $\mathrm{IH}-3,40$ & 3.40 & 3.33 & 1.87 & $2 \mathrm{H}-6,65$ & 15.45 & 5.22 & & $4 \mathrm{H}-4,31$ & 31.11 & 0.05 & \\
\hline $1 \mathrm{H}-3,66$ & 3.66 & 0.00 & 3.90 & $2 \mathrm{H}-6,89$ & 15.69 & 5.75 & 2.94 & $4 \mathrm{H}-5,145$ & 33.75 & 0.97 & \\
\hline $1 \mathrm{H}-3,86$ & 3.86 & 6.44 & 1.79 & $2 \mathrm{H}-6,114$ & 15.94 & & 1.84 & $4 \mathrm{H}-6,15$ & 33.95 & 0.15 & \\
\hline $1 \mathrm{H}-3,106$ & 4.06 & 14.89 & & $2 \mathrm{H}-7,10$ & 16.40 & 3.83 & 2.12 & $4 \mathrm{H}-6,31$ & 34.11 & 0.19 & \\
\hline $1 \mathrm{H}-3,120$ & 4.20 & 7.00 & 1.83 & $2 \mathrm{H}-7,15$ & 16.45 & 4.48 & & $4 \mathrm{H}-6,65$ & 34.45 & 0.55 & \\
\hline IH- 3,135 & 4.35 & 5.43 & & $2 \mathrm{H}-7,23$ & 16.53 & 9.00 & & $4 \mathrm{H}-6,90$ & 34.70 & 0.42 & \\
\hline $\mathrm{IH}-4,10$ & 4.60 & 7.66 & 1.37 & $2 \mathrm{H}-7,35$ & 16.65 & 8.63 & & $4 \mathrm{H}-6,135$ & 35.15 & 0.00 & \\
\hline IH-4, 15 & 4.65 & & 1.84 & $2 \mathrm{H}-7,47$ & 16.77 & & 2.08 & $4 \mathrm{H}-7.5$ & 35.35 & 0.00 & \\
\hline $1 \mathrm{H}-4,23$ & 4.73 & 15.42 & & $2 \mathrm{H}-\mathrm{CC}, 5$ & 16.80 & 5.11 & & $4 \mathrm{H}-7,35$ & 35.55 & 0.02 & \\
\hline $1 \mathrm{H}-4,35$ & 4.85 & & 1.91 & $3 \mathrm{H}-1,5$ & 16.85 & 2.70 & & $4 \mathrm{H}-7,69$ & 35.89 & 0.00 & \\
\hline $1 \mathrm{H}-4,44$ & 4.94 & 14.82 & 1.23 & $3 \mathrm{H}-1,32$ & 17.12 & 0.17 & 3.00 & $5 \mathrm{H}-1,19$ & 35.99 & 0.28 & \\
\hline $1 \mathrm{H}-4,55$ & 5.05 & 11.86 & 1.20 & $3 \mathrm{H}-1,65$ & 17.45 & 0.46 & & $5 \mathrm{H}-1,80$ & 36.60 & 0.76 & \\
\hline $1 \mathrm{H}-4,85$ & 5.35 & 0.78 & & $3 \mathrm{H}-1,90$ & 17.70 & 0.02 & 3.33 & $5 \mathrm{H}-2,19$ & 37.49 & 0.27 & 2.50 \\
\hline $1 \mathrm{H}-4,110$ & 5.60 & 0.00 & 3.03 & $3 \mathrm{H}-1,115$ & 17.95 & 0.22 & & $5 \mathrm{H}-2,120$ & 38.50 & 8.00 & \\
\hline $1 \mathrm{H}-4,125$ & 5.75 & 0.43 & & $3 \mathrm{H}-1,135$ & 18.15 & 0.38 & & $5 \mathrm{H}-3,10$ & 38.90 & 0.00 & \\
\hline $1 \mathrm{H}-4,135$ & 5.85 & 1.19 & & $3 \mathrm{H}-2,5$ & 18.35 & 1.48 & & $5 \mathrm{H}-3,110$ & 39.90 & 0.00 & \\
\hline $1 \mathrm{H}-5,16$ & 6.16 & 10.67 & & $3 \mathrm{H}-2,31$ & 18.61 & 0.24 & & $5 \mathrm{H}-4,9$ & 40.39 & 4.53 & \\
\hline IH-5, 34 & 6.34 & 10.01 & & $3 \mathrm{H}-2,55$ & 18.85 & 1.24 & & $5 \mathrm{H}-4,90$ & 41.20 & 0.00 & \\
\hline IH $-5,44$ & 6.44 & & 1.44 & $3 \mathrm{H}-2,70$ & 19.00 & 0.27 & 2.87 & $5 \mathrm{H}-5,31$ & 42.11 & 0.11 & \\
\hline $1 \mathrm{H}-5,54$ & 6.54 & 27.14 & & $3 \mathrm{H}-2,105$ & 19.35 & 0.17 & & $5 \mathrm{H}-5,90$ & 42.70 & 0.00 & \\
\hline $\mathrm{IH}-5,65$ & 6.65 & 53.53 & & $3 \mathrm{H}-2,135$ & 19.65 & 1.67 & & $5 \mathrm{H}-6,31$ & 43.61 & 0.00 & \\
\hline $1 \mathrm{H}-5,68$ & 6.68 & 26.93 & 1.39 & $3 \mathrm{H}-3,5$ & 19.85 & 0.95 & & $5 \mathrm{H}-6,130$ & 44.60 & 0.00 & \\
\hline $1 \mathrm{H}-5,75$ & 6.75 & 1.06 & & $3 \mathrm{H}-3,25$ & 20.05 & 1.52 & & $5 \mathrm{H}-7,43$ & 45.23 & 2.37 & \\
\hline $1 \mathrm{H}-5,80$ & 6.80 & 0.17 & 2.46 & $3 \mathrm{H}-3,41$ & 20.21 & 0.25 & 3.04 & $6 \mathrm{H}-1,54$ & 45.84 & 32.07 & \\
\hline 1H-CC, 8 & 7.08 & 0.00 & 2.73 & $3 \mathrm{H}-3,65$ & 20.45 & 0.12 & & $6 \mathrm{H}-1,110$ & 46.40 & 0.00 & \\
\hline $2 \mathrm{H}-\mathrm{I}, 5$ & 7.35 & 0.39 & & $3 \mathrm{H}-3,90$ & 20.70 & 0.68 & & $6 \mathrm{H}-2,9$ & 46.89 & 1.23 & \\
\hline $2 \mathrm{H}-1,31$ & 7.61 & 1.89 & 2.44 & $3 \mathrm{H}-3,115$ & 20.95 & 0.00 & & $6 \mathrm{H}-2,90$ & 47.70 & 0.23 & \\
\hline $2 \mathrm{H}-1,48$ & 7.78 & 1.30 & 3.18 & $3 \mathrm{H}-3,135$ & 21.15 & 0.22 & & $6 \mathrm{H}-3,31$ & 48.61 & 0.00 & \\
\hline $2 \mathrm{H}-1,65$ & 7.95 & 0.50 & & $3 \mathrm{H}-4,9$ & 21.39 & 0.00 & & $6 \mathrm{H}-3,110$ & 49.40 & 0.37 & \\
\hline $2 \mathrm{H}-\mathrm{I}, 94$ & 8.24 & 1.17 & & $3 \mathrm{H}-4,36$ & 21.66 & 0.00 & & $6 \mathrm{H}-4,31$ & 50.11 & 0.74 & \\
\hline $2 \mathrm{H}-\mathrm{I}, 110$ & 8.40 & 5.33 & 2.03 & $3 \mathrm{H}-4,65$ & 21.95 & 0.87 & & $6 \mathrm{H}-4,110$ & 50.90 & 0.00 & \\
\hline $2 \mathrm{H}-1,126$ & 8.56 & 8.81 & & $3 \mathrm{H}-4,96$ & 22.26 & 0.22 & & $6 \mathrm{H}-5,52$ & 51.82 & 0.00 & \\
\hline $2 \mathrm{H}-1,144$ & 8.74 & 1.93 & & $3 \mathrm{H}-4,120$ & 22.50 & 0.66 & 3.50 & $6 \mathrm{H}-5,110$ & 52.40 & 0.00 & \\
\hline $2 \mathrm{H}-2,4$ & 8.84 & 2.27 & & $3 \mathrm{H}-5,5$ & 22.85 & 0.69 & & $6 \mathrm{H}-6,31$ & 53.11 & 0.00 & \\
\hline $2 \mathrm{H}-2,16$ & 8.96 & 10.02 & & $3 \mathrm{H}-5,3 \mathrm{l}$ & 23.11 & 0.16 & & $6 \mathrm{H}-6,130$ & 54.10 & 0.25 & \\
\hline $2 \mathrm{H}-2,31$ & 9.11 & 5.25 & 2.41 & $3 \mathrm{H}-5,61$ & 23.41 & 0.63 & 2.60 & $6 \mathrm{H}-7,11$ & 54.41 & 0.00 & \\
\hline $2 \mathrm{H}-2,35$ & 9.15 & 4.23 & & $3 \mathrm{H}-5,96$ & 23.76 & 1.09 & & $7 \mathrm{H}-1,9$ & 54.89 & 0.17 & \\
\hline $2 \mathrm{H}-2,43$ & 9.23 & 4.22 & 2.09 & $3 \mathrm{H}-5,125$ & 24.05 & 0.00 & & $7 \mathrm{H}-1,48$ & 55.28 & 0.00 & \\
\hline $2 \mathrm{H}-2,65$ & 9.45 & 7.37 & & $3 \mathrm{H}-6,5$ & 24.35 & 0.42 & & $7 \mathrm{H}-2,9$ & 56.39 & 0.15 & \\
\hline $2 \mathrm{H}-2,82$ & 9.62 & 1.08 & 2.75 & $3 \mathrm{H}-6,31$ & 24.61 & 0.04 & 3.29 & $7 \mathrm{H}-2,49$ & 56.79 & 0.00 & \\
\hline $2 \mathrm{H}-2,105$ & 9.85 & 1.43 & & $3 \mathrm{H}-6,55$ & 24.85 & 0.01 & & $7 \mathrm{H}-3,49$ & 58.29 & 58.57 & 2.24 \\
\hline $2 \mathrm{H}-2,135$ & 10.15 & 0.00 & & $3 \mathrm{H}-6,89$ & 25.19 & 0.80 & 3.00 & $7 \mathrm{H}-3,130$ & 59.10 & 0.09 & \\
\hline $2 \mathrm{H}-3,5$ & 10.35 & 9.99 & & $3 \mathrm{H}-6,115$ & 24.45 & 0.00 & & $7 \mathrm{H}-4,9$ & 59.39 & 0.32 & \\
\hline $2 \mathrm{H}-3,16$ & 10.46 & 11.06 & & $3 \mathrm{H}-6,145$ & 25.75 & 0.00 & & $7 \mathrm{H}-4,90$ & 60.20 & 3.33 & \\
\hline $2 \mathrm{H}-3,30$ & 10.60 & 25.16 & 2.43 & $3 \mathrm{H}-7,5$ & 25.85 & 2.54 & & & & & \\
\hline
\end{tabular}


Table 1.3. Bulk carbonate content and SEM dissolution indices of Site 909 .

\begin{tabular}{|c|c|c|c|c|}
\hline Hole & $\begin{array}{l}\text { Core, section, } \\
\text { interval }(\mathrm{cm})\end{array}$ & $\begin{array}{l}\text { Depth } \\
\text { (mbsf) }\end{array}$ & $\begin{array}{l}\mathrm{CaCO}_{3} \\
(\mathrm{wt} \%)\end{array}$ & $\begin{array}{l}\text { Dissolution } \\
\text { index }\end{array}$ \\
\hline A & $1 \mathrm{H}-1,6$ & 0.06 & 4.04 & \\
\hline A & $1 \mathrm{H}-1,16$ & 0.16 & 0.37 & 3.48 \\
\hline A & $1 \mathrm{H}-1,26$ & 0.26 & 0.15 & \\
\hline A & $1 \mathrm{H}-1,44$ & 0.44 & 8.59 & 1.34 \\
\hline A & $1 \mathrm{H}-1,46$ & 0.46 & 7.80 & \\
\hline A & $1 \mathrm{H}-1,66$ & 0.66 & 8.22 & \\
\hline A & $1 \mathrm{H}-1,70$ & 0.70 & & 1.29 \\
\hline A & $1 \mathrm{H}-1,76$ & 0.76 & 0.70 & \\
\hline A & $1 \mathrm{H}-1,86$ & 0.86 & 1.45 & \\
\hline A & $1 \mathrm{H}-1,9$ & 0.96 & 0.03 & \\
\hline A & $1 \mathrm{H}-1,106$ & 1.06 & 3.97 & \\
\hline A & $1 \mathrm{H}-1,110$ & 1.10 & 5.04 & \\
\hline A & $1 \mathrm{H}-1,126$ & 1.26 & 2.21 & \\
\hline A & IH-1. 146 & 1.46 & 0.91 & \\
\hline A & $1 \mathrm{H}-2,6$ & 1.56 & 1.78 & \\
\hline A & $1 \mathrm{H}-2,16$ & 1.66 & 2.48 & \\
\hline A & 1H- 2,19 & 1.69 & 4.47 & 3.27 \\
\hline A & $1 \mathrm{H}-2,27$ & 1.77 & 2.87 & 4.00 \\
\hline A & $1 \mathrm{H}-2,36$ & 1.86 & 1.78 & \\
\hline A & $1 \mathrm{H}-2,46$ & 1.96 & 1.70 & \\
\hline A & $1.2-2,56$ & 2.06 & 2.55 & \\
\hline A & IH- $-2,66$ & 2.16 & 3.70 & \\
\hline A & $1 \mathrm{H}-2,86$ & 2.36 & 0.68 & \\
\hline A & $1 \mathrm{H}-2,96$ & 2.46 & 0.38 & \\
\hline A & $1 \mathrm{H}-2,104$ & 2.54 & & 1.94 \\
\hline A & $1 \mathrm{H}-2,106$ & 2.56 & 1.47 & \\
\hline A & $1 \mathrm{H}-2,116$ & 2.66 & 4.85 & \\
\hline A & $1 \mathrm{H}-2,126$ & 2.76 & 4.71 & \\
\hline A & $1 \mathrm{H}-2,136$ & 2.86 & 6.78 & \\
\hline A & $1 \mathrm{H}-2,138$ & 2.88 & 8.16 & 1.78 \\
\hline A & $1 \mathrm{H}-2,146$ & 2.96 & 8.31 & \\
\hline A & $1 \mathrm{H}-3,6$ & 3.06 & 10.18 & \\
\hline A & iH $-3,16$ & 3.16 & 3.26 & \\
\hline A & 1H- 3,26 & 3.26 & 0.00 & \\
\hline A & $1 \mathrm{H}-3,36$ & 3.36 & 2.26 & \\
\hline A & $1 \mathrm{H}-3,45$ & 3.45 & 2.10 & 2.97 \\
\hline A & $1 \mathrm{H}-3,46$ & 3.46 & 2.61 & \\
\hline A & 1H-3, 56 & 3.56 & 0.32 & \\
\hline A & $1 \mathrm{H}-3,66$ & 3.66 & 1.32 & \\
\hline A & IH $-3,76$ & 3.76 & 4.05 & \\
\hline A & IH $-3,86$ & 3.86 & 6.01 & \\
\hline A & $1 \mathrm{H}-3,96$ & 3.96 & 7.29 & \\
\hline $\mathrm{A}$ & $1 \mathrm{H}-3,106$ & 4.06 & 0.59 & \\
\hline A & $1 \mathrm{H}-3,116$ & 4.16 & 0.57 & \\
\hline A & $1 \mathrm{H}-3,121$ & 4.21 & 0.90 & \\
\hline A & $1 \mathrm{H}-3,126$ & 4.26 & 0.59 & \\
\hline A & $1 \mathrm{H}-4,7$ & 4.57 & & 2.25 \\
\hline A & IH $-4,34$ & 4.84 & 3.98 & 1.93 \\
\hline A & $\mathrm{IH}-4,42$ & 4.92 & & 1.23 \\
\hline $\mathrm{A}$ & $1 \mathrm{H}-4,114$ & 5.64 & 6.08 & 1.73 \\
\hline A & IH-5, 3 & 6.03 & 0.00 & \\
\hline A & IH-5, 6 & 6.06 & & 3.00 \\
\hline A & IH $-5,44$ & 6.44 & & 2.24 \\
\hline A & IH $-5,87$ & 6.87 & & 1.08 \\
\hline A & $1 \mathrm{H}-5,65$ & 6.65 & 0.68 & \\
\hline A & 1H-CC, 3 & 7.15 & 0.49 & \\
\hline A & $1 \mathrm{H}-\mathrm{CC} 5$ & 7.17 & 0.44 & 2.63 \\
\hline A & $2 \mathrm{H}-1,6$ & 7.56 & 0.02 & \\
\hline B & $2 \mathrm{H}-1,8$ & 7.58 & 0.50 & \\
\hline A & $2 \mathrm{H}-1,16$ & 7.66 & & 2.37 \\
\hline B & $2 \mathrm{H}-1,18$ & 7.68 & 0.16 & \\
\hline B & $2 \mathrm{H}-1,28$ & 7.78 & 9.88 & \\
\hline B & $2 \mathrm{H}-1,38$ & 7.88 & 0.09 & \\
\hline B & $2 \mathrm{H}-1,48$ & 7.98 & 0.05 & \\
\hline B & $2 \mathrm{H}-1,58$ & 8.08 & 0.09 & \\
\hline B & $2 \mathrm{H}-1,68$ & 8.18 & 8.66 & \\
\hline B & $2 \mathrm{H}-1,78$ & 8.28 & 10.43 & \\
\hline B & $2 \mathrm{H}-1,88$ & 8.38 & 0.38 & \\
\hline B & $2 \mathrm{H}-1,98$ & 8.48 & 2.78 & \\
\hline A & $2 \mathrm{H}-1,99$ & 8.49 & 0.86 & \\
\hline B & $2 \mathrm{H}-1,108$ & 8.58 & 0.48 & \\
\hline B & $2 \mathrm{H}-1,118$ & 8.68 & 0.46 & \\
\hline B & $2 \mathrm{H}-\mathrm{i}, 128$ & 8.78 & 0.17 & \\
\hline B & $2 \mathrm{H}-1,138$ & 8.88 & 0.43 & \\
\hline B & $2 \mathrm{H}-1,146$ & 8.96 & 0.65 & \\
\hline A & $2 \mathrm{H}-2,3$ & 9.03 & 0.21 & \\
\hline A & $2 \mathrm{H}-2,7$ & 9.07 & & 2.75 \\
\hline B & $2 \mathrm{H}-2,8$ & 9.08 & 2.51 & \\
\hline B & $2 \mathrm{H}-2,18$ & 9.18 & 1.37 & \\
\hline B & $2 \mathrm{H}-2,28$ & 9.28 & 0.40 & \\
\hline B & $2 \mathrm{H}-2,38$ & 9.38 & 4.16 & \\
\hline B & $2 \mathrm{H}-2,48$ & 9.48 & 4.74 & \\
\hline B & $2 \mathrm{H}-2,58$ & 9.58 & 0.61 & \\
\hline B & $2 \mathrm{H}-2,68$ & 9.68 & 0.21 & \\
\hline B & $2 \mathrm{H}-2,78$ & 9.78 & 0.18 & \\
\hline B & $2 \mathrm{H}-2,88$ & 9.88 & 0.41 & \\
\hline A & $2 \mathrm{H}-2,95$ & 9.95 & 7.19 & \\
\hline B & $2 \mathrm{H}-2,98$ & 9.98 & 0.13 & \\
\hline A & $2 \mathrm{H}-2,107$ & 10.07 & & 2.09 \\
\hline
\end{tabular}

\begin{tabular}{|c|c|c|c|c|}
\hline Hole & $\begin{array}{l}\text { Core, section, } \\
\text { interval }(\mathrm{cm})\end{array}$ & $\begin{array}{l}\text { Depth } \\
\text { (mbsf) }\end{array}$ & $\begin{array}{l}\mathrm{CaCO}_{3} \\
(\mathrm{wt} \%)\end{array}$ & $\begin{array}{l}\text { Dissolution } \\
\text { index }\end{array}$ \\
\hline B & $2 \mathrm{H}-2,108$ & 10.08 & 0.26 & \\
\hline B & $2 \mathrm{H}-2,118$ & 10.18 & 0.26 & \\
\hline B & $2 \mathrm{H}-2,128$ & 10.28 & 0.14 & \\
\hline B & $2 \mathrm{H}-2,138$ & 10.38 & 0.11 & \\
\hline $\mathrm{B}$ & $2 \mathrm{H}-2,148$ & 10.48 & 0.40 & \\
\hline A & $2 \mathrm{H}-3,36$ & 10.86 & 2.04 & \\
\hline A & $2 \mathrm{H}-3,100$ & 11.50 & 0.36 & 2.00 \\
\hline A & $2 \mathrm{H}-3,147$ & 11.97 & & 2.75 \\
\hline $\mathrm{A}$ & $2 \mathrm{H}-4,42$ & 12.42 & 4.32 & 2.16 \\
\hline A & $2 \mathrm{H}-4,77$ & 12.77 & 2.41 & 2.89 \\
\hline$\ddot{A}$ & $2 \mathrm{H}-4,105$ & 13.05 & & 1.78 \\
\hline A & $2 \mathrm{H}-5,10$ & 13.60 & & 3.79 \\
\hline A & $2 \mathrm{H}-5,56$ & 14.06 & 0.03 & \\
\hline A & $2 \mathrm{H}-5,144$ & 14.94 & 7.92 & \\
\hline A & $2 \mathrm{H}-6,15$ & 15.15 & 1.20 & \\
\hline $\mathrm{A}$ & $2 \mathrm{H}-6,100$ & 16.00 & 0.91 & \\
\hline A & $2 \mathrm{H}-7,45$ & 16.95 & 2.16 & 2.40 \\
\hline A & $3 \mathrm{H}-1,34$ & 17.34 & 11.58 & 2.21 \\
\hline A & $3 \mathrm{H}-\mathrm{I}, 100$ & 18.00 & 0.00 & \\
\hline A & $3 \mathrm{H}-2,39$ & 18.89 & 0.46 & \\
\hline A & $3 \mathrm{H}-2,106$ & 19.56 & 3.90 & \\
\hline A & $3 \mathrm{H}-3,33$ & 20.33 & 1.04 & \\
\hline A & $3 \mathrm{H}-3,83$ & 20.83 & 1.02 & 3.03 \\
\hline A & $3 \mathrm{H}-4,35$ & 21.85 & 1.45 & \\
\hline $\mathrm{A}$ & $3 \mathrm{H}-4,100$ & 22.50 & 2.51 & \\
\hline $\mathrm{A}$ & $3 \mathrm{H}-5,83$ & 23.83 & 3.31 & \\
\hline A & $3 \mathrm{H}-5,107$ & 24.07 & & 1.80 \\
\hline A & $3 \mathrm{H}-5,131$ & 24.31 & 1.56 & \\
\hline A & $3 \mathrm{H}-6,20$ & 24.70 & 1.52 & \\
\hline $\mathrm{A}$ & $3 \mathrm{H}-6-41$ & 24.91 & & 1.89 \\
\hline A & $3 \mathrm{H}-6-101$ & 25.51 & 0.16 & \\
\hline $\mathrm{A}$ & $3 \mathrm{H}-7,17$ & 26.17 & 2.79 & \\
\hline A & $4 \mathrm{H}-1,15$ & 26.65 & 0.62 & 3.56 \\
\hline$\ddot{A}$ & $4 \mathrm{H}-1,45$ & 26.95 & & 3.59 \\
\hline A & $4 \mathrm{H}-1,94$ & 27.43 & 8.47 & \\
\hline A & $4 \mathrm{H}-2,16$ & 28.16 & 0.54 & \\
\hline $\mathrm{A}$ & $4 \mathrm{H}-2,72$ & 28.72 & & 2.84 \\
\hline A & $4 \mathrm{H}-2,120$ & 29.20 & 0.33 & \\
\hline A & $4 \mathrm{H}-3,27$ & 28.87 & & 3.00 \\
\hline A & $4 \mathrm{H}-3,77$ & 30.27 & 1.60 & \\
\hline A & $4 \mathrm{H}-3,120$ & 30.70 & 0.00 & \\
\hline A & $4 \mathrm{H}-4,34$ & 31.34 & 0.12 & \\
\hline A & $4 \mathrm{H}-4,100$ & 32.00 & 2.94 & \\
\hline A & $4 \mathrm{H}-5,16$ & 32.66 & 0.00 & \\
\hline A & $4 \mathrm{H}-5-114$ & 33.64 & 0.76 & \\
\hline $\mathrm{A}$ & $4 \mathrm{H}, 6-49$ & 34.49 & 7.75 & \\
\hline A & $4 \mathrm{H}, 6-101$ & 35.01 & 2.36 & \\
\hline A & $4 \mathrm{H}, 7-27$ & 35.77 & 2.17 & \\
\hline A & $4 \mathrm{H}, \mathrm{CC}-6$ & 35.96 & 0.82 & \\
\hline A & $5 \mathrm{H}, 1-35$ & 36.35 & 3.20 & \\
\hline $\mathrm{A}$ & $5 \mathrm{H}, 1-85$ & 36.85 & 0.00 & \\
\hline $\mathrm{A}$ & $5 \mathrm{H}, 1-129$ & 37.29 & & 2.70 \\
\hline A & $5 \mathrm{H}, 2-47$ & 37.97 & 2.68 & \\
\hline A & $5 \mathrm{H}-2,98$ & 38.48 & 0.00 & \\
\hline A & $5 \mathrm{H}-3,26$ & 39.26 & 0.00 & \\
\hline A & $5 \mathrm{H}-3,116$ & 40.16 & 0.21 & \\
\hline A & $5 \mathrm{H}-4,20$ & 40.70 & 0.00 & \\
\hline A & $5 \mathrm{H}-4,83$ & 41.33 & 0.00 & \\
\hline A & $5 \mathrm{H}-4,113$ & 41.63 & & \\
\hline A & $5 \mathrm{H}-5,38$ & 42.38 & 0.00 & 2.42 \\
\hline $\mathrm{A}$ & $5 \mathrm{H}-5,130$ & 43.30 & 0.00 & \\
\hline A & $5 \mathrm{H}-6,38$ & 43.88 & 0.00 & \\
\hline A & $5 \mathrm{H}-6,137$ & 44.87 & 0.00 & \\
\hline $\mathrm{A}$ & $5 \mathrm{H}-7,13$ & 45.13 & 0.00 & \\
\hline A & $6 \mathrm{H}-1,26$ & 45.76 & 0.00 & \\
\hline A & $6 \mathrm{H}-1,78$ & 46.28 & & 3.45 \\
\hline A & $6 \mathrm{H}-1,120$ & 46.70 & 0.68 & \\
\hline A & $6 \mathrm{H}-2,13$ & 47.13 & 0.00 & \\
\hline A & $6 \mathrm{H}-2,33$ & 47.33 & 0.00 & \\
\hline A & $6 \mathrm{H}-3,35$ & 48.12 & 0.00 & \\
\hline A & $6 \mathrm{H}-4,34$ & 49.94 & 0.00 & \\
\hline A & $6 \mathrm{H}-4,102$ & 49.62 & 0.00 & \\
\hline A & $6 \mathrm{H}-5,41$ & 50.41 & 0.00 & \\
\hline A & $6 \mathrm{H}-5,102$ & 51.02 & 0.10 & \\
\hline $\mathrm{A}$ & $6 \mathrm{H}-6,41$ & 51.84 & 0.00 & \\
\hline A & $6 \mathrm{H}-6,100$ & 52.42 & 2.04 & \\
\hline A & $6 \mathrm{H}-7,27$ & 53.12 & 0.00 & \\
\hline A & $6 \mathrm{H}-7,100$ & 53.84 & 3.21 & \\
\hline A & $7 \mathrm{H}-1,16$ & 55.66 & 3.61 & \\
\hline A & $7 \mathrm{H}-1,87$ & 56.37 & 0.00 & \\
\hline A & $7 \mathrm{H}-2,36$ & 57.06 & 2.41 & \\
\hline $\mathrm{A}$ & $7 \mathrm{H}-2,94$ & 57.64 & 1.86 & \\
\hline A & $7 \mathrm{H}-3,33$ & 58.53 & 0.00 & \\
\hline A & $7 \mathrm{H}-3,86$ & 59.06 & 0.00 & \\
\hline $\mathrm{A}$ & $7 \mathrm{H}-4,37$ & 59.77 & 0.00 & \\
\hline $\mathrm{A}$ & $7 \mathrm{H}-4,87$ & 60.17 & 0.00 & \\
\hline A & $7 \mathrm{H}-5,41$ & 61.01 & 0.00 & \\
\hline A & $7 \mathrm{H}-5,86$ & 61.46 & 0.00 & \\
\hline A & $7 \mathrm{H}-6,37$ & 62.37 & 0.00 & \\
\hline
\end{tabular}


Table 1.3 (continued).

\begin{tabular}{|c|c|c|c|c|}
\hline Hole & $\begin{array}{l}\text { Core, section, } \\
\text { interval }(\mathrm{cm})\end{array}$ & $\begin{array}{l}\text { Depth } \\
\text { (mbsf) }\end{array}$ & $\begin{array}{l}\mathrm{CaCO}_{3} \\
(\mathrm{wt} \%)\end{array}$ & $\begin{array}{l}\text { Dissolution } \\
\text { index }\end{array}$ \\
\hline A & $7 \mathrm{H}-6,120$ & 63.20 & 0.29 & \\
\hline $\mathrm{A}$ & $7 \mathrm{H}-7,41$ & 63.71 & 2.01 & \\
\hline A & $7 \mathrm{H}-7-117$ & 64.47 & 0.00 & \\
\hline A & $8 \mathrm{H}, 1-33$ & 65.33 & 0.18 & 3.97 \\
\hline A & $8 \mathrm{H}, 1-95$ & 65.95 & 0.00 & \\
\hline A & $8 \mathrm{H}, 2-41$ & 66.81 & 0.00 & \\
\hline A & $8 \mathrm{H}-2,115$ & 67.55 & 0.78 & \\
\hline A & $8 \mathrm{H}-3,45$ & 68.35 & 0.92 & \\
\hline A & $8 \mathrm{H}-3,114$ & 68.94 & 0.00 & \\
\hline A & $8 \mathrm{H}-4,37$ & 69.58 & 0.00 & \\
\hline A & $8 \mathrm{H}-4,94$ & 70.14 & 0.00 & \\
\hline A & $8 \mathrm{H}-5,15$ & 70.74 & 0.71 & \\
\hline A & $8 \mathrm{H}-5,67$ & 71.27 & 14.71 & \\
\hline A & $8 \mathrm{H}-6,35$ & 71.99 & 0.00 & \\
\hline A & $8 \mathrm{H}-7,41$ & 72.71 & 0.05 & \\
\hline A & $8 \mathrm{H}-7,100$ & 73.30 & 0.00 & \\
\hline A & $9 \mathrm{H}-1,41$ & 74.41 & 0.57 & \\
\hline A & $9 \mathrm{H}-1,87$ & 74.87 & 0.00 & \\
\hline A & $9 \mathrm{H}-2,41$ & 75.81 & 0.00 & \\
\hline A & $9 \mathrm{H}-2,94$ & 76.34 & 0.60 & \\
\hline A & $9 \mathrm{H}-3,41$ & 77.21 & 0.26 & \\
\hline A & $9 \mathrm{H}-3,120$ & 78.00 & 1.13 & \\
\hline A & $9 \mathrm{H}-4,41$ & 78.65 & 0.00 & \\
\hline A & $9 \mathrm{H}-4,85$ & 79.05 & 0.00 & \\
\hline A & $9 \mathrm{H}-5,41$ & 80.01 & 0.00 & \\
\hline A & $9 \mathrm{H}-5,85$ & 80.45 & 0.00 & \\
\hline A & $9 \mathrm{H}-6,41$ & 61.41 & 1.79 & \\
\hline A & $9 \mathrm{H}-6,85$ & 61.85 & 3.52 & \\
\hline A & $9 \mathrm{H}-7,15$ & 82.55 & 3.07 & \\
\hline A & $10 \mathrm{H}-1,42$ & 83.02 & 0.00 & \\
\hline A & $10 \mathrm{H}-1,100$ & 83.60 & 0.00 & \\
\hline A & $11 \mathrm{H}-1,41$ & 84.81 & 0.58 & \\
\hline A & $11 \mathrm{H}-1,100$ & 85.40 & 0.00 & \\
\hline C & $1 \mathrm{R}-1,41$ & 85.41 & 0.13 & \\
\hline C & IR-1, 118 & 86.18 & 0.35 & \\
\hline A & $11 \mathrm{H}-2,41$ & 86.21 & 0.18 & \\
\hline A & $11 \mathrm{H}-2,85$ & 86.65 & 1.27 & \\
\hline A & $11 \mathrm{H}-3,2$ & 87.22 & 14.14 & \\
\hline A & $11 \mathrm{H}-3,80$ & 88.00 & 0.00 & \\
\hline A & $11 \mathrm{H}-4,41$ & 89.04 & 1.70 & \\
\hline A & $11 \mathrm{H}-4,120$ & 89.80 & 0.16 & \\
\hline A & $11 \mathrm{H}-5,37$ & 90.37 & 0.00 & \\
\hline A & $11 \mathrm{H}-5,108$ & 91.07 & 0.54 & \\
\hline A & $11 \mathrm{H}-6,41$ & 91.85 & 1.61 & \\
\hline C & $3 R-2,41$ & 106.21 & 2.37 & \\
\hline C & $3 R-2,119$ & 106.44 & 0.12 & \\
\hline C & $3 \mathrm{R}-1,41$ & 104.71 & 0.16 & \\
\hline C & 3R-1, 119 & 105.49 & 0.26 & \\
\hline C & $4 \mathrm{R}-1,40$ & 114.30 & 0.27 & \\
\hline C & $4 \mathrm{R}-1,114$ & 115.04 & 0.19 & \\
\hline C & $4 \mathrm{R}-2,40$ & 115.80 & 0.12 & \\
\hline C & $4 \mathrm{R}-2,114$ & 116.54 & 0.21 & \\
\hline C & $4 \mathrm{R}-3,40$ & 117.23 & 0.09 & \\
\hline C & $5 \mathrm{R}-1,41$ & 124.01 & 0.05 & \\
\hline C & $6 \mathrm{R}-1,41$ & 133.61 & 0.05 & \\
\hline C & $6 \mathrm{R}-1,116$ & 134.36 & 0.07 & \\
\hline C & $6 \mathrm{R}-2,41$ & 135.11 & 0.10 & \\
\hline C & $6 \mathrm{R}-2,116$ & 135.86 & 0.18 & \\
\hline C & $6 \mathrm{R}-3,41$ & 136.61 & 0.02 & \\
\hline C & $6 \mathrm{R}-3,116$ & 137.36 & 0.21 & \\
\hline C & $6 \mathrm{R}-4,41$ & 138.11 & 0.04 & \\
\hline $\mathrm{C}$ & $7 \mathrm{R}-1,41$ & 143.31 & 0.24 & \\
\hline C & $7 \mathrm{R}-2,41$ & 144.81 & 0.03 & \\
\hline C & $7 \mathrm{R}-2,115$ & 145.55 & 0.06 & \\
\hline C & $7 \mathrm{R}-3,41$ & 146.31 & 0.05 & \\
\hline $\mathrm{C}$ & $7 \mathrm{R}-3,115$ & 147.05 & 0.02 & \\
\hline C & $7 \mathrm{R}-4,41$ & 147.51 & 0.32 & \\
\hline C & $7 R-4,115$ & 148.55 & 0.07 & \\
\hline $\mathrm{C}$ & $8 \mathrm{R}-1,44$ & 153.04 & 0.07 & \\
\hline $\mathrm{C}$ & $8 \mathrm{R}-1,117$ & 153.75 & 0.03 & \\
\hline C & $8 \mathrm{R}-2,41$ & 154.19 & 0.16 & \\
\hline C & $8 \mathrm{R}-2,117$ & 154.94 & 0.03 & \\
\hline C & $8 \mathrm{R}-3,31$ & 155.91 & 0.07 & \\
\hline C & $8 \mathrm{R}-3,117$ & 156.77 & 0.05 & \\
\hline C & $8 R-4,41$ & 157.51 & 0.02 & \\
\hline $\mathrm{C}$ & $8 \mathrm{R}-4,114$ & 158.24 & 0.06 & \\
\hline C & $8 R-5,41$ & 159.01 & 0.07 & \\
\hline $\mathrm{C}$ & $8 R-5,116$ & 159.76 & 0.12 & \\
\hline C & $9 \mathrm{R}-1,41$ & 162.71 & 0.20 & \\
\hline C & $9 \mathrm{R}-1,118$ & 163.52 & 0.16 & \\
\hline C & $9 \mathrm{R}-2,41$ & 164.21 & 0.17 & \\
\hline $\mathrm{C}$ & 9R-2, 118 & 165.08 & 0.14 & \\
\hline $\mathrm{C}$ & $9 \mathrm{R}-3,41$ & 165.71 & 0.14 & \\
\hline C & 9R-3, 118 & 166.49 & 0.34 & \\
\hline $\mathrm{C}$ & $9 \mathrm{R}-4,41$ & 167.21 & 0.27 & \\
\hline
\end{tabular}

\begin{tabular}{|c|c|c|c|c|}
\hline Hole & $\begin{array}{l}\text { Core, section, } \\
\text { interval }(\mathrm{cm})\end{array}$ & $\begin{array}{l}\text { Depth } \\
\text { (mbsf) }\end{array}$ & $\begin{array}{l}\mathrm{CaCO}_{3} \\
(w \mathrm{t} \%)\end{array}$ & $\begin{array}{l}\text { Dissolution } \\
\text { index }\end{array}$ \\
\hline C & $9 R-4,118$ & 167.98 & 2.10 & \\
\hline C & $9 \mathrm{R}-5,41$ & 168.71 & 0.07 & \\
\hline C & $10 \mathrm{R}-1,41$ & 172.31 & 0.07 & \\
\hline C & $10 \mathrm{R}-1,116$ & 173.16 & 0.07 & \\
\hline C & $10 \mathrm{R}-2,41$ & 173.91 & 2.71 & \\
\hline C & $10 \mathrm{R}-2,118$ & 174.68 & 0.17 & \\
\hline C & $10 \mathrm{R}-3,41$ & 175.31 & 3.50 & \\
\hline $\mathrm{C}$ & $10 \mathrm{R}-3,116$ & 176.06 & 0.14 & \\
\hline C & $10 \mathrm{R}-4,41$ & 176.81 & 0.10 & \\
\hline C & $10 \mathrm{R}-4,116$ & 177.26 & 0.04 & \\
\hline C & $10 \mathrm{R}-5,41$ & 178.31 & 0.14 & \\
\hline C & $10 \mathrm{R}-5,116$ & 179.06 & 0.12 & \\
\hline C & $10 \mathrm{R}-6,41$ & 179.81 & 0.34 & \\
\hline $\mathrm{C}$ & 10R-6, 116 & 180.56 & 2.17 & \\
\hline C & $11 \mathrm{R}-1,41$ & 182.01 & 0.90 & \\
\hline $\mathrm{C}$ & $11 \mathrm{R}-1,117$ & 182.77 & 0.38 & \\
\hline C & $11 \mathrm{R}-2,41$ & 183.51 & 0.51 & \\
\hline $\mathrm{C}$ & $11 \mathrm{R}-2,115$ & 184.25 & 0.00 & \\
\hline C & $11 \mathrm{R}-3,43$ & 185.03 & 0.00 & \\
\hline C & $11 \mathrm{R}-3,117$ & 185.77 & 0.00 & \\
\hline C & $1 \mathrm{IR}-4,41$ & 186.51 & 0.00 & \\
\hline C & $11 \mathrm{R}-4,117$ & 187.27 & 0.51 & \\
\hline $\mathrm{C}$ & $11 \mathrm{R}-5,41$ & 188.03 & 0.83 & \\
\hline C & $11 \mathrm{R}-5,117$ & 188.77 & 2.09 & \\
\hline C & $1 \mathrm{IR}-6,41$ & 189.51 & 2.36 & \\
\hline $\mathrm{C}$ & $12 \mathrm{R}-1,38$ & 191.58 & 2.59 & \\
\hline C & $12 \mathrm{R}-1,115$ & 192.35 & 0.00 & \\
\hline C & $12 \mathrm{R}-2,40$ & 193.00 & 0.00 & \\
\hline C & $12 \mathrm{R}-2,115$ & 193.75 & 0.00 & \\
\hline $\mathrm{C}$ & $12 \mathrm{R}-3,40$ & 194.50 & 0.00 & \\
\hline $\mathrm{C}$ & $12 \mathrm{R}-3,115$ & 195.35 & 0.00 & \\
\hline C & $12 \mathrm{R}-4,40$ & 196.10 & 0.00 & \\
\hline C & $12 \mathrm{R}-4,115$ & 196.85 & 0.00 & \\
\hline C & $12 \mathrm{R}-5,40$ & 197.60 & 0.00 & \\
\hline C & $13 \mathrm{R}-1,41$ & 197.61 & 0.00 & \\
\hline C & $13 \mathrm{R}-1,117$ & 201.97 & 0.00 & \\
\hline $\mathrm{C}$ & $13 \mathrm{R}-2,41$ & 202.71 & 0.00 & \\
\hline C & $13 \mathrm{R}-2,117$ & 203.47 & 0.00 & \\
\hline C & $13 R-3,40$ & 204.20 & 0.00 & \\
\hline C & $13 \mathrm{R}-3,117$ & 204.97 & 0.08 & \\
\hline C & $13 \mathrm{R}-4,45$ & 205.75 & 0.00 & \\
\hline C & $13 \mathrm{R}-4,117$ & 206.47 & 0.74 & \\
\hline C & $13 \mathrm{R}-5,41$ & 207.21 & 0.00 & \\
\hline C & $13 \mathrm{R}-5,117$ & 207.97 & 0.18 & \\
\hline C & $13 \mathrm{R}-6,41$ & 208.71 & 1.56 & \\
\hline C & $13 \mathrm{R}-6,117$ & 209.74 & 14.89 & \\
\hline $\mathrm{C}$ & $14 \mathrm{R}-1,41$ & 210.91 & 2.19 & \\
\hline C & $14 \mathrm{R}-1,116$ & 211.66 & 1.68 & \\
\hline C & $14 \mathrm{R}-2,41$ & 212.41 & 0.91 & \\
\hline $\mathrm{C}$ & $14 \mathrm{R}-2,116$ & 213.16 & 1.09 & \\
\hline C & $14 \mathrm{R}-3,41$ & 213.91 & 0.92 & \\
\hline C & $14 \mathrm{R}-3,116$ & 214.66 & 0.94 & \\
\hline C & $14 \mathrm{R}-4,41$ & 215.41 & 1.17 & \\
\hline C & $14 \mathrm{R}-4,116$ & 216.16 & 0.87 & \\
\hline C & $14 \mathrm{R}-5,41$ & 216.91 & 0.00 & \\
\hline C & $14 \mathrm{R}-5,116$ & 217.66 & 0.00 & \\
\hline C & $14 \mathrm{R}-6,41$ & 218.41 & 0.00 & \\
\hline $\mathrm{C}$ & $15 \mathrm{R}-1,41$ & 220.51 & 10.80 & \\
\hline C & $15 \mathrm{R}-1,116$ & 221.32 & 0.00 & \\
\hline $\mathrm{C}$ & $15 \mathrm{R}-2,41$ & 222.07 & 0.85 & \\
\hline C & $15 \mathrm{R}-2,116$ & 222.82 & 0.00 & \\
\hline C & $15 \mathrm{R}-3,41$ & 223,51 & 1.02 & \\
\hline C & $15 \mathrm{R}-3,116$ & 224.26 & 0.00 & \\
\hline $\mathrm{C}$ & $15 R-4,41$ & 225.01 & 0.00 & \\
\hline $\mathrm{C}$ & $15 \mathrm{R}-4,116$ & 226.76 & 0.52 & \\
\hline C & $16 \mathrm{R}-1,41$ & 230.01 & 0.12 & \\
\hline C & $16 \mathrm{R}-1,116$ & 230.77 & 0.00 & \\
\hline C & $16 \mathrm{R}-2,41$ & 231.51 & 0.12 & \\
\hline C & $16 \mathrm{R}-2,116$ & 232.26 & 0.72 & \\
\hline C & $16 \mathrm{R}-3,41$ & 233.01 & 0.00 & \\
\hline $\mathrm{C}$ & $16 \mathrm{R}-3,116$ & 233.76 & 0.00 & \\
\hline $\mathrm{C}$ & $16 \mathrm{R}-4,41$ & 234.51 & 0.00 & \\
\hline C & $16 \mathrm{R}-4,116$ & 235.26 & 2.23 & \\
\hline C & $17 \mathrm{R}-1,41$ & 239.61 & 0.00 & \\
\hline $\mathrm{C}$ & $17 \mathrm{R}-1,115$ & 240.36 & 0.00 & \\
\hline $\mathrm{C}$ & $17 R-2,41$ & 241.12 & 0.00 & \\
\hline C & $17 \mathrm{R}-2,115$ & 241.87 & 0.00 & \\
\hline C & $17 \mathrm{R}-3,41$ & 242.61 & 0.00 & \\
\hline C & $17 R-3,115$ & 243.35 & 0.00 & \\
\hline $\mathrm{C}$ & $17 \mathrm{R}-4,41$ & 244.11 & 0.00 & \\
\hline C & $17 \mathrm{R}-4,115$ & 244.87 & 0.00 & \\
\hline C & $17 \mathrm{R}-5,41$ & 245.62 & 0.00 & \\
\hline C & $17 \mathrm{R}-5,115$ & 246.36 & 0.00 & \\
\hline C & 17R-6, 41 & 246.90 & 0.00 & \\
\hline
\end{tabular}


VARIATIONS IN SURFACE WATER MASS CONDITIONS

Table 2.1. Number of foraminifers (specimen/g of sediment) at Site 644.

\begin{tabular}{|c|c|c|c|c|c|c|c|c|c|c|c|}
\hline $\begin{array}{l}\text { Core, section, } \\
\text { interval }(\mathrm{cm})\end{array}$ & $\begin{array}{l}\text { Depth } \\
\text { (mbsf) }\end{array}$ & $\begin{array}{c}\text { Benthic } \\
\text { foraminifers } \\
\text { (spec. } / g \text { ) }\end{array}$ & $\begin{array}{l}\text { Planktonic } \\
\text { foraminifers } \\
\text { (spec./g) }\end{array}$ & $\begin{array}{c}N . \\
\text { pachyderma } \\
\text { sinistral } \\
\text { (spec./g) }\end{array}$ & $\begin{array}{c}\text { Subpolar } \\
\text { planktonic } \\
\text { foraminifers } \\
(\text { spec. } / g)\end{array}$ & $\begin{array}{l}\text { Core, section, } \\
\text { interval }(\mathrm{cm})\end{array}$ & $\begin{array}{l}\text { Depth } \\
\text { (mbsf) }\end{array}$ & $\begin{array}{c}\text { Benthic } \\
\text { foraminifers } \\
\text { (spec./g) }\end{array}$ & $\begin{array}{l}\text { Planktonic } \\
\text { foraminifers } \\
\text { (spec./g) }\end{array}$ & $\begin{array}{c}N . \\
\text { pachyderma } \\
\text { sinistral } \\
\text { (spec./g) }\end{array}$ & $\begin{array}{c}\text { Subpolar } \\
\text { planktonic } \\
\text { foraminifers } \\
\text { (spec. } / \mathrm{g} \text { ) }\end{array}$ \\
\hline $104-644 \mathrm{~A}-$ & & & & & & $17 \mathrm{H}-4,58$ & 154.28 & 25.5 & 24.0 & 20.2 & 3.8 \\
\hline $1 \mathrm{H}-1,102$ & 1.02 & 19.3 & 84.4 & 82.4 & 2.0 & $17 \mathrm{H}-5,139$ & 156.59 & 375.9 & 69.6 & 58.1 & 11.4 \\
\hline $1 \mathrm{H}-3,102$ & 4.02 & 35.0 & 287.2 & 259.8 & 27.4 & $18 \mathrm{H}-1,122$ & 159.92 & 97.9 & 46.4 & 40.0 & 6.4 \\
\hline $2 \mathrm{H}-1,122$ & 10.42 & 17.3 & 303.6 & 263.2 & 40.4 & $18 \mathrm{H}-2,102$ & 161.22 & 1.7 & 2.0 & 0.5 & 1.6 \\
\hline $2 \mathrm{H}-2,122$ & 11.92 & 18.3 & 274.0 & 247.2 & 26.8 & $18 \mathrm{H}-3,42$ & 162.12 & 2.8 & 5.3 & 1.3 & 4.0 \\
\hline $2 \mathrm{H}-4,142$ & 15.12 & 258.3 & 4365.7 & 3745.7 & 620.0 & $18 \mathrm{H}-4,102$ & 164.22 & 0.2 & 0.1 & 0.0 & 0.1 \\
\hline $3 \mathrm{H}-4,102$ & 21.72 & 25.8 & 426.0 & 403.1 & 22.9 & $18 \mathrm{H}-5,102$ & 165.72 & 6.7 & 287.2 & 226.6 & 60.6 \\
\hline $3 \mathrm{H}-6,96$ & 24.66 & 379.8 & 12888.6 & 12686.1 & 202.6 & $18 \mathrm{H}-7,42$ & 168.12 & 2.4 & 0.7 & 0.3 & 0.4 \\
\hline $4 \mathrm{H}-2,102$ & 28.22 & 17.2 & 46.9 & 45.1 & 1.7 & $19 \mathrm{H}-2,100$ & 170.70 & 3.6 & 0.0 & 0.0 & 0.0 \\
\hline $4 \mathrm{H}-4,142$ & 31.62 & 0.1 & 0.2 & 0.2 & 0.0 & $19 \mathrm{H}-3,120$ & 172.40 & 1.8 & 22.8 & 0.0 & 22.8 \\
\hline $4 \mathrm{H}-5,122$ & 32.92 & 18.6 & 117.0 & 114.2 & 2.8 & $19 \mathrm{H}-4,22$ & 172.92 & 12.0 & 1.8 & 0.1 & 1.7 \\
\hline $5 \mathrm{H}-1,141$ & 36.61 & 0.0 & 0.1 & 0.1 & 0.0 & $19 \mathrm{H}-4,100$ & 173.70 & 5.5 & 1.3 & 0.0 & 1.3 \\
\hline $5 \mathrm{H}-2,102$ & 37.72 & 636.0 & 1760.0 & 1720.0 & 40.0 & $20 \mathrm{H}-1,42$ & 178.12 & 0.1 & 0.0 & 0.0 & 0.0 \\
\hline $6 \mathrm{H}-3,101$ & 48.71 & 41.0 & 97.1 & 91.3 & 5.8 & $20 \mathrm{H}-1,142$ & 179.12 & 49.3 & 58.7 & 0.0 & 58.7 \\
\hline $6 \mathrm{H}-6,66$ & 53.06 & 168.0 & 629.3 & 589.9 & 39.3 & $20 \mathrm{H}-2,142$ & 180.62 & 495.6 & 286.5 & 0.0 & 286.5 \\
\hline $7 \mathrm{H}-1,14$ & 54.34 & 213.3 & 1112.6 & 1053.5 & 59.1 & $20 \mathrm{H}-3,122$ & 181.92 & 24.1 & 10.3 & 0.0 & 10.3 \\
\hline $7 \mathrm{H}-2,127$ & 56.97 & 0.4 & 0.1 & 0.1 & 0.0 & $20 \mathrm{H}-4,122$ & 183.42 & 0.5 & 0.0 & 0.0 & 0.0 \\
\hline $7 \mathrm{H}-3,3$ & 57.23 & 62.6 & 140.1 & 133.7 & 6.4 & $20 \mathrm{H}-5,42$ & 184.12 & 25.7 & 0.7 & 0.0 & 0.7 \\
\hline $8 \mathrm{H}-1,79$ & 64.49 & 133.0 & 594.6 & 559.4 & 35.2 & $20 \mathrm{H}-5,82$ & 184.52 & 4.3 & 0.9 & 0.0 & 0.9 \\
\hline $8 \mathrm{H}-7,3$ & 72.73 & 72.7 & 2989.0 & 2906.0 & 83.0 & $20 \mathrm{H}-5,102$ & 184.72 & 0.0 & 0.0 & 0.0 & 0.0 \\
\hline $9 \mathrm{H}-2,82$ & 75.52 & 4.2 & 14.8 & 14.0 & 0.8 & $21 \mathrm{H}-1,22$ & 185.02 & 26.6 & 175.2 & 1.7 & 173.5 \\
\hline $9 \mathrm{H}-5,3$ & 79.23 & 13.8 & 63.2 & 60.8 & 2.4 & $21 \mathrm{H}-1,62$ & 185.42 & 0.1 & 0.3 & 0.0 & 0.3 \\
\hline $9 \mathrm{H}-5,135$ & 82.15 & 8.0 & 40.8 & 40.2 & 0.6 & $21 \mathrm{H}-1,102$ & 185.82 & 0.0 & 0.0 & 0.0 & 0.0 \\
\hline $10 \mathrm{H}-1,41$ & 83.11 & 3.8 & 239.7 & 226.2 & 13.5 & $22 \mathrm{H}-\mathrm{I}, 22$ & 187.02 & 14.4 & 0.7 & 0.0 & 0.7 \\
\hline $10 \mathrm{H}-2,142$ & 85.62 & 34.5 & 568.2 & 503.2 & 64.9 & $22 \mathrm{H}-2,42$ & 188.72 & 62.5 & 0.4 & 0.0 & 0.4 \\
\hline $10 \mathrm{H}-3,22$ & 85.92 & 39.2 & 83.7 & 57.6 & 26.1 & $22 \mathrm{H}-3,22$ & 190.02 & 0.0 & 0.0 & 0.0 & 0.0 \\
\hline $10 \mathrm{H}-5,3$ & 88.73 & 2.3 & 457.8 & 439.5 & 18.3 & $22 \mathrm{H}-3,102$ & 190.82 & 0.1 & 0.2 & 0.2 & 0.1 \\
\hline $10 \mathrm{H}-6,58$ & 90.78 & 4.2 & 8.8 & 8.2 & 0.6 & $22 \mathrm{H}-4,42$ & 191.72 & 12.8 & 7.5 & 0.1 & 7.4 \\
\hline $11 \mathrm{H}-1,22$ & 92.42 & 2.5 & 6.9 & 6.4 & 0.5 & $22 \mathrm{H}-4,121$ & 192.51 & 0.0 & 0.1 & 0.1 & 0.0 \\
\hline $11 \mathrm{H}-4,42$ & 97.12 & 34.4 & 267.9 & 252.8 & 15.1 & $22 \mathrm{H}-5,42$ & 193.22 & 3.4 & 0.8 & 0.2 & 0.6 \\
\hline $11 \mathrm{H}-6,122$ & 100.92 & 107.2 & 953.6 & 782.4 & 171.2 & $23 \mathrm{H}-1,39$ & 194.49 & 14.5 & 9.4 & 0.2 & 9.2 \\
\hline $12 \mathrm{H}-1,122$ & 102.92 & 1.1 & 3.7 & 3.3 & 0.4 & $23 \mathrm{H}-2,42$ & 196.02 & 3.6 & 20.2 & 0.1 & 20.2 \\
\hline $12 \mathrm{H}-2,62$ & 103.82 & 0.1 & 0.6 & 0.4 & 0.2 & $23 \mathrm{H}-2,102$ & 196.62 & 8.6 & 4.4 & 0.0 & 4.4 \\
\hline $12 \mathrm{H}-2,102$ & 104.22 & 54.4 & 888.0 & 871.0 & 17.0 & $23 \mathrm{H}-3,102$ & 198.12 & 3.4 & 0.2 & 0.0 & 0.2 \\
\hline $12 \mathrm{H}-3,62$ & 105.32 & 0.3 & 5.1 & 4.7 & 0.4 & $23 \mathrm{H}-5,122$ & 201.32 & 12.9 & 82.2 & 0.0 & 82.2 \\
\hline $12 \mathrm{H}-4,22$ & 106.42 & 44.7 & 55.5 & 48.4 & 7.1 & $24 \mathrm{H}-1,122$ & 202.32 & 0.0 & 0.1 & 0.0 & 0.1 \\
\hline $12 \mathrm{H}-6,42$ & 109.62 & 0.0 & 0.5 & 0.5 & 0.0 & $24 \mathrm{H}-3,142$ & 205.52 & 0.8 & 0.1 & 0.0 & 0.1 \\
\hline $13 \mathrm{H}-4,102$ & 116.72 & 21.3 & 16.8 & 15.9 & 1.0 & $25 \mathrm{H}-2,62$ & 208.12 & 7.7 & 20.8 & 0.0 & 20.8 \\
\hline $13 \mathrm{H}-6,62$ & 119.32 & 164.4 & 48.0 & 44.4 & 3.6 & $25 \mathrm{H}-3,42$ & 209.42 & 3.3 & 6.0 & 0.0 & 6.0 \\
\hline $13 \mathrm{H}-7,102$ & 121.22 & 44.9 & 70.2 & 57.8 & 12.4 & $26 \mathrm{H}-1,22$ & 210.72 & 3.7 & 0.4 & 0.0 & 0.4 \\
\hline $14 \mathrm{H}-1,99$ & 122.69 & 2.1 & 0.0 & 0.0 & 0.0 & $26 \mathrm{H}-1,62$ & 211.12 & 0.0 & 0.0 & 0.0 & 0.0 \\
\hline $14 \mathrm{H}-2,3$ & 123.23 & 12.3 & 25.7 & 25.1 & 0.6 & $26 \mathrm{H}-2,22$ & 212.22 & 74.4 & 17.4 & 1.9 & 15.6 \\
\hline $14 \mathrm{H}-4,3$ & 125.23 & 28.7 & 10.5 & 10.2 & 0.3 & $26 \mathrm{H}-2,122$ & 213.22 & 10.7 & 1.5 & 0.2 & 1.4 \\
\hline $14 \mathrm{H}-4,117$ & 126.37 & 49.7 & 1.0 & 0.3 & 0.8 & $26 \mathrm{H}-3,22$ & 213.72 & 0.0 & 0.0 & 0.0 & 0.0 \\
\hline $15 \mathrm{H}-1,122$ & 131.42 & 18.1 & 4.0 & 0.0 & 4.0 & $27 \mathrm{H}-1,102$ & 215.32 & 14.9 & 3.9 & 0.2 & 3.8 \\
\hline $15 \mathrm{H}-2,22$ & 131.92 & 0.5 & 0.5 & 0.3 & 0.2 & $28 \mathrm{H}-1,142$ & 217.52 & 9.1 & 1.1 & 0.1 & 1.0 \\
\hline $15 \mathrm{H}-2,62$ & 132.32 & 0.4 & 0.0 & 0.0 & 0.0 & $29 \mathrm{H}-2,102$ & 223.62 & 0.0 & 0.0 & 0.0 & 0.0 \\
\hline $15 \mathrm{H}-2,102$ & 132.72 & 0.0 & 0.0 & 0.0 & 0.0 & $30 \mathrm{H}-2,102$ & 228.62 & 25.8 & 14.5 & 0.4 & 14.0 \\
\hline $15 \mathrm{H}-3,82$ & 134.02 & 35.5 & 18.3 & 13.1 & 5.2 & $31 \mathrm{H}-2,102$ & 234.62 & 0.0 & 0.0 & 0.0 & 0.0 \\
\hline $15 \mathrm{H}-7,42$ & 139.62 & 0.6 & 0.2 & 0.2 & 0.0 & $31 \mathrm{H}-2,142$ & 235.02 & 0.0 & 0.0 & 0.0 & 0.0 \\
\hline $16 \mathrm{H}-1,23$ & 139.93 & 28.1 & 21.0 & 16.8 & 4.2 & $32 \mathrm{H}-2,102$ & 240.62 & 8.0 & 3.4 & 0.1 & 3.3 \\
\hline $16 \mathrm{H}-2,23$ & 141.43 & 27.7 & 189.1 & 83.0 & 106.1 & $32 \mathrm{H}-3,102$ & 242.12 & 22.1 & 10.7 & 0.0 & 10.7 \\
\hline $16 \mathrm{H}-2,44$ & 141.64 & 13.8 & 18.1 & 10.7 & 7.4 & $33 \mathrm{H}-1,122$ & 244.92 & 17.1 & 11.3 & 0.0 & 11.3 \\
\hline $16 \mathrm{H}-4,120$ & 145.20 & 1.5 & 10.8 & 2.8 & 8.0 & $34 \mathrm{H}-2,122$ & 248.72 & 7.5 & 4.7 & 0.2 & 4.5 \\
\hline $16 \mathrm{H}-5,23$ & 145.93 & 2.5 & 96.3 & 26.1 & 70.3 & $34 \mathrm{H}-5,142$ & 251.92 & 10.8 & 9.9 & 0.0 & 9.9 \\
\hline $17 \mathrm{H}-1,58$ & 149.78 & 4.8 & 9.5 & 3.3 & 6.2 & & & & & & \\
\hline
\end{tabular}


Table 2.2. Number of foraminifers (specimen/g of sediment) at Site 907 .

\begin{tabular}{|c|c|c|c|c|c|c|c|c|c|c|c|}
\hline $\begin{array}{l}\text { Core, section, } \\
\text { interval }(\mathrm{cm})\end{array}$ & $\begin{array}{l}\text { Depth } \\
\text { (mbsf) }\end{array}$ & $\begin{array}{c}\text { Benthic } \\
\text { foraminifers } \\
\text { (spec./g) }\end{array}$ & $\begin{array}{l}\text { Planktonic } \\
\text { foraminifers } \\
\text { (spec./g) }\end{array}$ & $\begin{array}{c}\text { N. pachyderma } \\
\text { sinistral } \\
\text { (spec./g) }\end{array}$ & $\begin{array}{c}\text { Subpolar } \\
\text { planktonic } \\
\text { foraminifers } \\
(\text { spec } / g)\end{array}$ & $\begin{array}{l}\text { Core, section, } \\
\text { interval }(\mathrm{cm})\end{array}$ & $\begin{array}{l}\text { Depth } \\
\text { (mbsf) }\end{array}$ & $\begin{array}{c}\text { Benthic } \\
\text { foraminifers } \\
\text { (spec. } / \mathrm{g} \text { ) }\end{array}$ & $\begin{array}{c}\text { Planktonic } \\
\text { foraminifers } \\
(\text { spec. } / g)\end{array}$ & $\begin{array}{c}\text { N. pachyderma } \\
\text { sinistral } \\
\text { (spec./g) }\end{array}$ & $\begin{array}{c}\text { Subpolar } \\
\text { planktonic } \\
\text { foraminifers } \\
\text { (spec./g) }\end{array}$ \\
\hline $151-907 \mathrm{~A}-$ & & & & & & $3 \mathrm{H}-4,9$ & 21.39 & 0.0 & 0.1 & 0.1 & 0.0 \\
\hline IH- 1,8 & 0.08 & 1236.1 & 27121.1 & 19341.1 & 7780.1 & $3 \mathrm{H}-4,45$ & 21.85 & 0.0 & 0.0 & 0.0 & 0.0 \\
\hline $1 \mathrm{H}-1,24$ & 0.24 & 851.9 & 9521.5 & 7638.0 & 1883.5 & $3 \mathrm{H}-4,115$ & 22.45 & 0.0 & 0.0 & 0.0 & 0.0 \\
\hline $1 \mathrm{H}-1,44$ & 0.44 & 28.3 & 6329.4 & 5933.8 & 395.6 & $3 \mathrm{H}-4,120$ & 22.50 & 0.7 & 1.3 & 0.9 & 0.5 \\
\hline $1 \mathrm{H}-1,65$ & 0.65 & 16.7 & 1100.0 & 962.5 & 137.5 & $3 \mathrm{H}-5,31$ & 23.11 & 0.0 & 0.0 & 0.0 & 0.0 \\
\hline $1 \mathrm{H}-1,71$ & 0.71 & 43.8 & 2965.6 & 2583.0 & 382.6 & $3 \mathrm{H}-5,45$ & 23.25 & 0.0 & 0.0 & 0.0 & 0.0 \\
\hline $1 \mathrm{H}-1,85$ & 0.85 & 78.4 & 3724.4 & 3332.3 & 392.0 & $3 \mathrm{H}-5,61$ & 23.41 & 0.2 & 1.3 & 0.5 & 0.8 \\
\hline $1 \mathrm{H}-1,112$ & 1.12 & 31.8 & 3690.7 & 3142.6 & 548.2 & $3 \mathrm{H}-6,31$ & 24.61 & 0.2 & 0.6 & 0.5 & 0.2 \\
\hline $1 \mathrm{H}-1,143$ & 1.43 & 57.4 & 6371.3 & 5797.3 & 574.0 & $3 \mathrm{H}-6,44$ & 24.74 & 0.0 & 0.0 & 0.0 & 0.0 \\
\hline $1 \mathrm{H}-2,11$ & 1.61 & 194.7 & 7842.6 & 6785.8 & 1056.8 & $3 \mathrm{H}-6,89$ & 25.19 & 0.0 & 0.2 & 0.2 & 0.1 \\
\hline $1 \mathrm{H}-2,35$ & 1.85 & 525.7 & 18924.0 & 15454.6 & 3469.4 & $3 \mathrm{H}-7,10$ & 25.90 & 2.2 & 29.8 & 1.2 & 28.6 \\
\hline $\mathrm{IH}-2,45$ & 1.95 & 206.0 & 31111.5 & 21633.8 & 9477.7 & $3 \mathrm{H}-7,36$ & 26.26 & 0.0 & 0.0 & 0.0 & 0.0 \\
\hline $1 \mathrm{H}-2,55$ & 2.05 & 764.8 & 34433.7 & 25282.4 & 9151.4 & $4 \mathrm{H}-1,45$ & 26.75 & 0.0 & 0.0 & 0.0 & 0.0 \\
\hline $1 \mathrm{H}-2,75$ & 2.25 & 72.6 & 4838.1 & 3792.1 & 1046.1 & $4 \mathrm{H}-1,60$ & 26.90 & 0.0 & 0.1 & 0.0 & 0.1 \\
\hline $1 \mathrm{H}-2,110$ & 2.60 & 44.9 & 7862.6 & 6964.0 & 898.6 & $4 \mathrm{H}-1,78$ & 27.08 & 0.8 & 18.6 & 10.4 & 8.3 \\
\hline $1 \mathrm{H}-2,135$ & 2.85 & 166.5 & 6085.6 & 5327.2 & 758.4 & $4 \mathrm{H}-2,10$ & 27.90 & 0.1 & 0.3 & 0.2 & 0.1 \\
\hline $1 \mathrm{H}-3,5$ & 3.05 & 170.2 & 6189.3 & 5522.4 & 666.9 & $4 \mathrm{H}-2,115$ & 28.95 & 0.0 & 0.0 & 0.0 & 0.0 \\
\hline $1 \mathrm{H}-3,40$ & 3.40 & 96.5 & 1207.6 & 865.5 & 342.1 & $4 \mathrm{H}-2,120$ & 29.00 & 0.0 & 0.1 & 0.0 & 0.1 \\
\hline $\mathrm{IH}-3,66$ & 3.66 & 2.3 & 10.7 & 9.8 & 0.9 & $4 \mathrm{H}-3,48$ & 29.78 & 0.1 & 0.4 & 0.3 & 0.2 \\
\hline $1 \mathrm{H}-3,86$ & 3.86 & 71.4 & 2267.2 & 1535.3 & 731.9 & $4 \mathrm{H}-3,110$ & 30.40 & 0.6 & 1.9 & 1.3 & 0.6 \\
\hline $1 \mathrm{H}-3,120$ & 4.20 & 104.2 & 2708.7 & 1574.3 & 1134.4 & $4 \mathrm{H}-3,115$ & 30.45 & 0.0 & 0.0 & 0.0 & 0.0 \\
\hline $1 \mathrm{H}-3,135$ & 4.35 & 48.8 & 2267.4 & 1987.1 & 280.4 & $4 \mathrm{H}-4,31$ & 31.11 & 0.0 & 0.1 & 0.0 & 0.1 \\
\hline $\mathrm{IH}-4,6$ & 4.56 & 148.8 & 8007.5 & 7382.3 & 625.1 & $4 \mathrm{H}-4,100$ & 31.80 & 0.0 & 0.1 & 0.0 & 0.1 \\
\hline $1 \mathrm{H}-4,10$ & 4.60 & 244.8 & 7363.9 & 6221.6 & 1142.3 & $4 \mathrm{H}-4,115$ & 31.95 & 0.0 & 0.0 & 0.0 & 0.0 \\
\hline $1 \mathrm{H}-4,15$ & 4.65 & 27.8 & 2491.5 & 2250.7 & 240.8 & $4 \mathrm{H}-5,17$ & 32.47 & 0.0 & 0.0 & 0.0 & 0.0 \\
\hline $1 \mathrm{H}-4,35$ & 4.85 & 19.8 & 3299.1 & 2952.3 & 346.8 & $4 \mathrm{H}-5,45$ & 32.75 & 0.0 & 0.0 & 0.0 & 0.0 \\
\hline $1 \mathrm{H}-4,44$ & 4.94 & 302.5 & 9642.5 & 9151.0 & 491.6 & $4 \mathrm{H}-5,110$ & 33.40 & 0.0 & 0.1 & 0.1 & 0.0 \\
\hline $1 \mathrm{H}-4,110$ & 5.60 & 0.7 & 4.7 & 4.5 & 0.2 & $4 \mathrm{H}-6,31$ & 34.11 & 0.0 & 0.0 & 0.0 & 0.0 \\
\hline $\mathrm{IH}-5,44$ & 6.44 & 678.8 & 19830.3 & 18763.6 & 1066.7 & $4 \mathrm{H}-6,44$ & 34.24 & 0.0 & 0.0 & 0.0 & 0.0 \\
\hline IH $-5,68$ & 6.68 & 1250.3 & 119086.1 & 116898.2 & 2187.9 & $4 \mathrm{H}-6,90$ & 34.70 & 0.0 & 0.0 & 0.0 & 0.0 \\
\hline $1 \mathrm{H}-5,80$ & 6.80 & 4.2 & 62.6 & 58.4 & 4.2 & $4 \mathrm{H}-6,115$ & 34.95 & 0.0 & 0.0 & 0.0 & 0.0 \\
\hline IH-CC, 8 & 7.08 & 1.1 & 3.9 & 3.0 & 0.9 & $4 \mathrm{H}-7,42$ & 35.81 & 0.0 & 0.0 & 0.0 & 0.0 \\
\hline $2 \mathrm{H}-1,31$ & 7.61 & 4.5 & 116.4 & 113.1 & 3.3 & $4 \mathrm{H}-7,69$ & 35.98 & 0.0 & 0.0 & 0.0 & 0.0 \\
\hline $2 \mathrm{H}-1,48$ & 7.78 & 13.1 & 186.6 & 183.8 & 2.8 & $5 \mathrm{H}-1,19$ & 35.99 & 0.0 & 0.0 & 0.0 & 0.0 \\
\hline $2 \mathrm{H}-1,110$ & 8.40 & 65.0 & 9441.6 & 9225.1 & 216.6 & $5 \mathrm{H}-1,80$ & 36.60 & 0.0 & 0.1 & 0.1 & 0.0 \\
\hline $2 \mathrm{H}-2,31$ & 9.11 & 161.5 & 12142.5 & 10957.9 & 1184.6 & $5 \mathrm{H}-2,19$ & 37.49 & 0.0 & 0.1 & 0.1 & 0.0 \\
\hline $2 \mathrm{H}-2,43$ & 9.23 & 29.7 & 695.5 & 665.8 & 29.7 & $5 \mathrm{H}-2,120$ & 38.50 & 0.0 & 0.0 & 0.0 & 0.0 \\
\hline $2 \mathrm{H}-2,82$ & 9.62 & 0.3 & 1.4 & 1.2 & 0.2 & $5 \mathrm{H}-3,10$ & 38.90 & 0.0 & 0.0 & 0.0 & 0.0 \\
\hline $2 \mathrm{H}-2,116$ & 9.96 & 0.0 & 0.1 & 0.1 & 0.0 & $5 \mathrm{H}-3,110$ & 39.90 & 0.0 & 0.0 & 0.0 & 0.0 \\
\hline $2 \mathrm{H}-3,30$ & 10.60 & 627.9 & 20183.6 & 17761.6 & 2422.0 & $5 \mathrm{H}-4,9$ & 40.39 & 0.0 & 0.0 & 0.0 & 0.0 \\
\hline $2 \mathrm{H}-3,44$ & 10.74 & 86.0 & 3363.4 & 3165.6 & 197.9 & $5 \mathrm{H}-4,90$ & 41.20 & 0.0 & 0.0 & 0.0 & 0.0 \\
\hline $2 \mathrm{H}-3,108$ & 11.38 & 1014.1 & 14450.4 & 13994.1 & 456.3 & $5 \mathrm{H}-5,31$ & 42.11 & 0.0 & 0.0 & 0.0 & 0.0 \\
\hline $2 \mathrm{H}-3,116$ & 11.46 & 1.0 & 92.9 & 90.3 & 2.6 & $5 \mathrm{H}-5,90$ & 42.70 & 0.0 & 0.0 & 0.0 & 0.0 \\
\hline $2 \mathrm{H}-4,31$ & 12.11 & 9.6 & 532.2 & 513.1 & 19.1 & $5 \mathrm{H}-6,31$ & 43.61 & 0.0 & 0.0 & 0.0 & 0.0 \\
\hline $2 \mathrm{H}-4,44$ & 12.24 & 0.2 & 0.3 & 0.3 & 0.0 & $5 \mathrm{H}-6,130$ & 44.60 & 0.0 & 0.0 & 0.0 & 0.0 \\
\hline $2 \mathrm{H}-4,80$ & 12.60 & 0.3 & 2.0 & 1.8 & 0.2 & $5 \mathrm{H}-7,43$ & 45.23 & 0.0 & 0.0 & 0.0 & 0.0 \\
\hline $2 \mathrm{H}-4,115$ & 12.95 & 1.6 & 114.4 & 111.3 & 3.1 & $6 \mathrm{H}-1,54$ & 45.84 & 0.0 & 0.0 & 0.0 & 0.0 \\
\hline $2 \mathrm{H}-5,40$ & 13.70 & 34.1 & 730.3 & 699.6 & 30.6 & $6 \mathrm{H}-1,110$ & 46.40 & 0.0 & 0.0 & 0.0 & 0.0 \\
\hline $2 \mathrm{H}-5,47$ & 13.77 & 4.7 & 722.6 & 708.5 & 14.1 & $6 \mathrm{H}-2,9$ & 46.89 & 0.0 & 0.0 & 0.0 & 0.0 \\
\hline $2 \mathrm{H}-5,110$ & 14.40 & 4.7 & 83.5 & 66.8 & 16.7 & $6 \mathrm{H}-2,90$ & 47.70 & 0.0 & 0.0 & 0.0 & 0.0 \\
\hline $2 \mathrm{H}-5,115$ & 14.45 & 1.6 & 62.9 & 61.8 & 1.0 & $6 \mathrm{H}-3,31$ & 48.61 & 0.1 & 0.4 & 0.0 & 0.4 \\
\hline $2 \mathrm{H}-6,30$ & 15.10 & 76.7 & 1503.7 & 1383.3 & 120.4 & $6 \mathrm{H}-3,110$ & 49.40 & 0.0 & 0.0 & 0.0 & 0.0 \\
\hline $2 \mathrm{H}-6,47$ & 15.27 & 37.6 & 1048.5 & 978.0 & 70.5 & $6 \mathrm{H}-4,31$ & 50.11 & 0.0 & 0.0 & 0.0 & 0.0 \\
\hline $2 \mathrm{H}-6,89$ & 15.69 & 127.2 & 3204.5 & 2924.7 & 279.8 & $6 \mathrm{H}-4,110$ & 50.90 & 0.2 & 0.2 & 0.0 & 0.2 \\
\hline $2 \mathrm{H}-6,114$ & 15.94 & 192.6 & 5659.3 & 5525.9 & 133.3 & $6 \mathrm{H}-5,52$ & 51.82 & 0.1 & 0.0 & 0.0 & 0.0 \\
\hline $2 \mathrm{H}-7,10$ & 16.40 & 113.3 & 2410.8 & 2119.6 & 291.2 & $6 \mathrm{H}-5,110$ & 52.40 & 0.0 & 0.0 & 0.0 & 0.0 \\
\hline $2 \mathrm{H}-7,47$ & 16.77 & 4.1 & 701.7 & 632.7 & 69.0 & $6 \mathrm{H}-6,31$ & 53.11 & 0.0 & 0.0 & 0.0 & 0.0 \\
\hline $3 \mathrm{H}-1,32$ & 17.12 & 0.0 & 0.4 & 0.2 & 0.2 & $6 \mathrm{H}-6,130$ & 54.10 & 0.6 & 0.0 & 0.0 & 0.0 \\
\hline $3 \mathrm{H}-1,45$ & 17.25 & 0.0 & 0.0 & 0.0 & 0.0 & $6 \mathrm{H}-7,11$ & 54.41 & 0.0 & 0.0 & 0.0 & 0.0 \\
\hline $3 \mathrm{H}-1,90$ & 17.70 & 0.0 & 0.5 & 0.2 & 0.3 & $7 \mathrm{H}-1,9$ & 54.89 & 0.0 & 0.0 & 0.0 & 0.0 \\
\hline $3 \mathrm{H}-1,115$ & 17.95 & 0.0 & 1.0 & 0.9 & 0.1 & $7 \mathrm{H}-1,48$ & 55.28 & 0.0 & 0.5 & 0.0 & 0.5 \\
\hline $3 \mathrm{H}-2,31$ & 18.61 & 0.0 & 0.1 & 0.0 & 0.1 & $7 \mathrm{H}-2,9$ & 56.39 & 1.1 & 0.0 & 0.0 & 0.0 \\
\hline $3 \mathrm{H}-2,44$ & 18.74 & 0.0 & 0.0 & 0.0 & 0.0 & $7 \mathrm{H}-2,49$ & 56.79 & 0.1 & 0.0 & 0.0 & 0.0 \\
\hline $3 \mathrm{H}-2,70$ & 19.00 & 0.3 & 2.8 & 2.1 & 0.7 & $7 \mathrm{H}-3,49$ & 58.29 & 74.4 & 53.1 & 1.7 & 51.5 \\
\hline $3 \mathrm{H}-2,115$ & 19.45 & 0.0 & 0.0 & 0.0 & 0.0 & $7 \mathrm{H}-3,130$ & 59.10 & 0.2 & 0.4 & 0.0 & 0.4 \\
\hline $3 \mathrm{H}-3,41$ & 20.21 & 1.1 & 11.4 & 3.4 & 8.0 & $7 \mathrm{H}-4,9$ & 59.39 & 0.7 & 0.0 & 0.0 & 0.0 \\
\hline $3 \mathrm{H}-3,45$ & 20.25 & 0.0 & 0.0 & 0.0 & 0.0 & $7 \mathrm{H}-4,90$ & 60.20 & 7.5 & 0.0 & 0.0 & 0.0 \\
\hline $3 \mathrm{H}-3,90$ & 20.70 & 0.1 & 0.0 & 0.0 & 0.0 & & & & & & \\
\hline
\end{tabular}


Table 2.3. Number of foraminifers (specimen/g of sediment) at Site 909.

\begin{tabular}{|c|c|c|c|c|c|c|c|c|c|c|}
\hline $\begin{array}{l}\text { Core, section, } \\
\text { interval }(\mathrm{cm})\end{array}$ & $\begin{array}{l}\text { Depth } \\
\text { (mbsf) }\end{array}$ & $\begin{array}{c}\text { Benthic } \\
\text { foraminifers } \\
\text { (spec./g) }\end{array}$ & $\begin{array}{l}\text { Planktonic } \\
\text { foraminifers } \\
\text { (spec. } / \mathrm{g} \text { ) }\end{array}$ & $\begin{array}{l}\text { N. pachyderma } \\
\text { sinistral } \\
\text { (spec./g) }\end{array}$ & $\begin{array}{c}\text { Subpolar } \\
\text { planktonic } \\
\text { foraminifers } \\
\text { (spec. } / \mathrm{g} \text { ) }\end{array}$ & $\begin{array}{l}\text { Core, section, } \\
\text { interval }(\mathrm{cm})\end{array}$ & $\begin{array}{l}\text { Depth } \\
\text { (mbsf) }\end{array}$ & $\begin{array}{c}\text { Benthic } \\
\text { foraminifers } \\
\text { (spec./g) }\end{array}$ & $\begin{array}{c}\text { Planktonic } \\
\text { foraminifers } \\
\text { (spec. } / \mathrm{g} \text { ) }\end{array}$ & $\begin{array}{l}\text { N. pachyderma } \\
\text { sinistral } \\
\text { (spec./g) }\end{array}$ \\
\hline 151A-909- & & & & & & $5 \mathrm{H}-5,38$ & 42.38 & 0.5 & 2.7 & 1.1 \\
\hline $1 \mathrm{H}-1,10$ & 0.10 & 9.5 & 323.2 & 315.6 & 7.6 & $5 \mathrm{H}-6,91$ & 44.41 & 0.0 & 0.0 & 0.0 \\
\hline $1 \mathrm{H}-1,44$ & 0.44 & 57.2 & 2525.7 & 1969.9 & 555.8 & $5 \mathrm{H}-7,13$ & 45.13 & 0.0 & 0.0 & 0.0 \\
\hline $1 \mathrm{H}-1,91$ & 0.91 & 40.2 & 2953.9 & 2351.0 & 602.8 & $6 \mathrm{H}-1,26$ & 45.76 & 0.0 & 0.0 & 0.0 \\
\hline $1 \mathrm{H}-1,100$ & 1.00 & 12.8 & 1059.6 & 906.4 & 153.2 & $6 \mathrm{H}-1,91$ & 46.42 & 0.0 & 0.0 & 0.0 \\
\hline $1 \mathrm{H}-2,10$ & 1.60 & 0.4 & 4.7 & 4.4 & 0.3 & $6 \mathrm{H}-2,13$ & 47.13 & 0.0 & 0.0 & 0.0 \\
\hline $1 \mathrm{H}-2,19$ & 1.69 & 0.6 & 2.8 & 2.8 & 0.0 & $6 \mathrm{H}-2,33$ & 47.33 & 0.0 & 0.0 & 0.0 \\
\hline $1 \mathrm{H}-2,91$ & 2.41 & 0.0 & 0.0 & 0.0 & 0.0 & $6 \mathrm{H}-3,35$ & 48.05 & 0.0 & 0.0 & 0.0 \\
\hline $1 \mathrm{H}-2,138$ & 2.88 & 609.5 & 5056.8 & 5011.6 & 45.2 & $6 \mathrm{H}-4,34$ & 48.84 & 0.2 & 0.0 & 0.0 \\
\hline $\mathrm{IH}-3,10$ & 3.10 & 32.9 & 781.5 & 773.3 & 8.2 & $6 \mathrm{H}-5,10$ & 50.10 & 0.0 & 0.0 & 0.0 \\
\hline $1 \mathrm{H}-3,45$ & 3.45 & 0.1 & 7.3 & 6.6 & 0.7 & $6 \mathrm{H}-5,41$ & 50.41 & 0.0 & 0.0 & 0.0 \\
\hline $1 \mathrm{H}-3,91$ & 3.91 & 24.0 & 286.9 & 284.1 & 2.8 & $6 \mathrm{H}-6,10$ & 51.50 & 0.0 & 0.0 & 0.0 \\
\hline $1 \mathrm{H}-3,121$ & 4.21 & 0.0 & 0.1 & 0.1 & 0.0 & $6 \mathrm{H}-6,41$ & 51.81 & 0.0 & 0.0 & 0.0 \\
\hline $1 \mathrm{H}-4,10$ & 4.60 & 0.0 & 0.2 & 0.2 & 0.0 & $6 \mathrm{H}-7,27$ & 53.17 & 0.0 & 0.0 & 0.0 \\
\hline $1 \mathrm{H}-4,34$ & 4.84 & 0.3 & 7.0 & 6.9 & 0.1 & $6 \mathrm{H}-\mathrm{CC}, 10$ & 54.38 & 0.0 & 0.0 & 0.0 \\
\hline $1 \mathrm{H}-4,91$ & 5.41 & 0.0 & 2.1 & 1.9 & 0.2 & $7 \mathrm{H}-1,10$ & 55.60 & 0.0 & 0.0 & 0.0 \\
\hline $1 \mathrm{H}-4,114$ & 5.64 & 115.9 & 3709.6 & 2975.4 & 734.2 & $7 \mathrm{H}-1,16$ & 55.66 & 0.0 & 0.0 & 0.0 \\
\hline $1 \mathrm{H}-5,3$ & 6.03 & 0.4 & 15.7 & 15.4 & 0.4 & $7 \mathrm{H}-2,36$ & 57.36 & 0.0 & 0.0 & 0.0 \\
\hline $1 \mathrm{H}-5,10$ & 6.10 & 0.0 & 0.4 & 0.4 & 0.0 & $7 \mathrm{H}-3,10$ & 58.42 & 0.6 & 0.0 & 0.0 \\
\hline 1H-5, 65 & 6.65 & 0.1 & 17.4 & 16.9 & 0.5 & $7 \mathrm{H}-3,86$ & 59.36 & 0.0 & 0.0 & 0.0 \\
\hline $1 \mathrm{H}-5,91$ & 6.91 & 12.1 & 2510.4 & 2437.8 & 72.6 & $7 \mathrm{H}-4,88$ & 60.88 & 0.0 & 0.0 & 0.0 \\
\hline 1H-CC, 5 & 7.17 & 1.0 & 15.4 & 13.5 & 1.9 & $7 \mathrm{H}-5,86$ & 62.01 & 0.1 & 0.0 & 0.0 \\
\hline $1 \mathrm{H}-\mathrm{CC}, 10$ & 7.22 & 0.0 & 2.1 & 2.1 & 0.0 & $7 \mathrm{H}-5,91$ & 62.06 & 0.0 & 0.0 & 0.0 \\
\hline $2 \mathrm{H}-1,6$ & 7.56 & 1.6 & 38.0 & 35.7 & 2.4 & $7 \mathrm{H}-6,37$ & 63.37 & 0.1 & 0.0 & 0.0 \\
\hline $2 \mathrm{H}-1,10$ & 7.60 & 12.6 & 163.8 & 159.6 & 4.2 & $7 \mathrm{H}-6,120$ & 64.20 & 0.0 & 0.0 & 0.0 \\
\hline $2 \mathrm{H}-1,91$ & 8.41 & 0.0 & 0.5 & 0.5 & 0.0 & $7 \mathrm{H}-7,91$ & 64.97 & 0.0 & 0.0 & 0.0 \\
\hline $2 \mathrm{H}-1,99$ & 8.49 & 0.0 & 0.2 & 0.2 & 0.0 & $7 \mathrm{H}-7,117$ & 65.23 & 0.0 & 0.0 & 0.0 \\
\hline $2 \mathrm{H}-2,3$ & 9.03 & 0.0 & 0.0 & 0.0 & 0.0 & $8 \mathrm{H}-1,33$ & 65.33 & 0.0 & 4.3 & 4.3 \\
\hline $2 \mathrm{H}-2,10$ & 9.10 & 0.0 & 0.0 & 0.0 & 0.0 & $8 \mathrm{H}-1,91$ & 65.91 & 0.0 & 0.0 & 0.0 \\
\hline $2 \mathrm{H}-2,91$ & 9.91 & 120.9 & 1322.3 & 1201.4 & 120.9 & $8 \mathrm{H}-1,95$ & 65.95 & 0.1 & 0.0 & 0.0 \\
\hline $2 \mathrm{H}-2,95$ & 9.95 & 168.9 & 2449.3 & 2205.3 & 244.0 & $8 \mathrm{H}-2,41$ & 66.41 & 0.0 & 0.0 & 0.0 \\
\hline $2 \mathrm{H}-3,10$ & 10.60 & 0.3 & 5.6 & 4.4 & 1.2 & $8 \mathrm{H}-3,114$ & 68.84 & 0.0 & 0.1 & 0.1 \\
\hline $2 \mathrm{H}-3,36$ & 10.86 & 0.0 & 0.0 & 0.0 & 0.0 & $8 \mathrm{H}-4,10$ & 69.30 & 0.0 & 0.0 & 0.0 \\
\hline $2 \mathrm{H}-3,91$ & 11.41 & 0.0 & 0.1 & 0.1 & 0.0 & $8 \mathrm{H}-4,94$ & 70.14 & 0.4 & 0.1 & 0.1 \\
\hline $2 \mathrm{H}-3,100$ & 11.50 & 0.7 & 1.8 & 0.4 & 1.3 & $8 \mathrm{H}-5,15$ & 70.85 & 0.0 & 0.0 & 0.0 \\
\hline $2 \mathrm{H}-4,10$ & 12.10 & 0.0 & 0.0 & 0.0 & 0.0 & $8 \mathrm{H}-6,35$ & 71.15 & 0.0 & 0.0 & 0.0 \\
\hline $2 \mathrm{H}-4,42$ & 12.42 & 48.7 & 3114.8 & 3066.2 & 48.7 & $8 \mathrm{H}-7,91$ & 73.21 & 0.0 & 0.0 & 0.0 \\
\hline $2 \mathrm{H}-4,77$ & 12.77 & 0.2 & 1.7 & 1.6 & 0.2 & $8 \mathrm{H}-7,100$ & 73.30 & 0.1 & 0.0 & 0.0 \\
\hline $2 \mathrm{H}-4,91$ & 12.91 & 0.0 & 0.0 & 0.0 & 0.0 & $9 \mathrm{H}-1,87$ & 74.77 & 0.0 & 0.0 & 0.0 \\
\hline $2 \mathrm{H}-5,10$ & 13.60 & 0.0 & 1.7 & 1.5 & 0.2 & $9 \mathrm{H}-2,10$ & 75.50 & 0.0 & 0.0 & 0.0 \\
\hline $2 \mathrm{H}-5,56$ & 14.06 & 0.0 & 0.0 & 0.0 & 0.0 & $9 \mathrm{H}-2,94$ & 76.34 & 0.0 & 0.2 & 0.1 \\
\hline $2 \mathrm{H}-5,144$ & 14.94 & 20.8 & 473.5 & 452.7 & 20.8 & $9 \mathrm{H}-3,41$ & 77.31 & 0.0 & 0.0 & 0.0 \\
\hline $2 \mathrm{H}-6,10$ & 15.10 & 0.0 & 0.0 & 0.0 & 0.0 & $9 \mathrm{H}-4,10$ & 78.50 & 0.0 & 0.0 & 0.0 \\
\hline $2 \mathrm{H}-6,15$ & 15.15 & 1.8 & 0.5 & 0.4 & 0.1 & $9 \mathrm{H}-4,41$ & 78.81 & 0.0 & 0.0 & 0.0 \\
\hline $2 \mathrm{H}-6,91$ & 15.91 & 45.5 & 231.4 & 225.2 & 6.2 & $9 \mathrm{H}-5,41$ & 80.31 & 0.1 & 0.0 & 0.0 \\
\hline $2 \mathrm{H}-6,100$ & 16.00 & 0.1 & 0.4 & 0.4 & 0.0 & $9 \mathrm{H}-6,85$ & 81.85 & 0.1 & 0.1 & 0.0 \\
\hline $2 \mathrm{H}-7,45$ & 16.95 & 0.1 & 0.6 & 0.6 & 0.0 & $9 \mathrm{H}-7,15$ & 82.15 & 0.1 & 0.1 & 0.0 \\
\hline $3 \mathrm{H}-1,34$ & 17.34 & 35.5 & 1987.0 & 1945.6 & 41.4 & $9 \mathrm{H}-\mathrm{CC}, 10$ & 82.73 & 0.0 & 0.0 & 0.0 \\
\hline $3 \mathrm{H}-1,100$ & 18.00 & 0.0 & 0.0 & 0.0 & 0.0 & $10 \mathrm{H}-1,42$ & 83.02 & 0.0 & 0.0 & 0.0 \\
\hline $3 \mathrm{H}-2,39$ & 18.89 & 0.0 & 0.1 & 0.1 & 0.0 & $10 \mathrm{H}-1,98$ & 83.58 & 0.0 & 0.0 & 0.0 \\
\hline $3 \mathrm{H}-2,91$ & 19.41 & 0.4 & 14.2 & 14.1 & 0.1 & $11 \mathrm{H}-1,41$ & 84.71 & 0.0 & 0.0 & 0.0 \\
\hline $3 \mathrm{H}-2,106$ & 19.56 & 1.6 & 8.2 & 8.0 & 0.2 & & & & & \\
\hline $3 \mathrm{H}-3,33$ & 20.33 & 0.0 & 0.3 & 0.3 & 0.0 & $151-909 \mathrm{C}-$ & & & & 00 \\
\hline $3 \mathrm{H}-3,83$ & 20.83 & 0.2 & 12.3 & 12.1 & 0.2 & IR-1, 41 & 85.41 & 0.0 & 0.3 & 0.0 \\
\hline $3 \mathrm{H}-4,35$ & 21.85 & 0.0 & 0.1 & 0.1 & 0.0 & $151-909 \mathrm{~A}-$ & & & & \\
\hline $3 \mathrm{H}-4,100$ & 22.50 & 0.1 & 0.1 & 0.0 & 0.1 & $11 \mathrm{H}-2,41$ & 86.21 & 0.0 & 0.0 & 0.0 \\
\hline $3 \mathrm{H}-5,9$ & 23.09 & 39.8 & 2934.4 & 2708.7 & 225.7 & $11 \mathrm{H}-2,90$ & 86.70 & 0.0 & 0.0 & 0.0 \\
\hline $3 \mathrm{H}-5,81$ & 23.81 & 180.3 & 2360.1 & 2294.5 & 65.6 & $11 \mathrm{H}-3,2$ & 87.32 & 0.4 & 0.0 & 0.0 \\
\hline $3 \mathrm{H}-5,91$ & 23.91 & 58.0 & 376.4 & 367.0 & 9.4 & $11 \mathrm{H}-4,90$ & 89.50 & 0.0 & 0.0 & 0.0 \\
\hline $3 \mathrm{H}-5,131$ & 24.31 & 0.0 & 0.2 & 0.1 & 0.1 & $11 \mathrm{H}-4,120$ & 89.80 & 0.0 & 0.0 & 0.0 \\
\hline $3 \mathrm{H}-6,20$ & 24.60 & 0.7 & 4.3 & 4.1 & 0.1 & $11 \mathrm{H}-5,37$ & 90.47 & 0.0 & 0.0 & 0.0 \\
\hline $3 \mathrm{H}-6,91$ & 25.41 & 0.0 & 0.0 & 0.0 & 0.0 & $11 \mathrm{H}-6,10$ & 91.50 & 0.0 & 0.0 & 0.0 \\
\hline $3 \mathrm{H}-6,101$ & 25.51 & 0.0 & 0.1 & 0.1 & 0.1 & $11 \mathrm{H}-6,41$ & 91.81 & 0.1 & 0.0 & 0.0 \\
\hline $3 \mathrm{H}-7,17$ & 26.10 & 0.1 & 0.8 & 0.7 & 0.1 & & & & & \\
\hline $3 \mathrm{H}-\mathrm{CC}$ & 26.57 & 0.0 & 75.2 & 0.0 & 75.2 & $151-909 \mathrm{C}$ & & & & \\
\hline $4 \mathrm{H}, 1,10$ & 26.60 & 0.9 & 11.6 & 10.9 & 0.7 & $3 \mathrm{R}-1,41$ & 104.81 & 0.8 & 0.3 & 0.0 \\
\hline $4 \mathrm{H}-1,15$ & 26.65 & 0.0 & 5.5 & 5.3 & 0.2 & $3 \mathrm{R}-1,119$ & 105.49 & 0.0 & 0.1 & 0.1 \\
\hline $4 \mathrm{H}-1,91$ & 27.41 & 13.1 & 467.0 & 450.4 & $\begin{array}{l}0.2 \\
16.7\end{array}$ & $4 \mathrm{R}-1,40$ & 114.30 & 0.0 & 0.0 & 0.0 \\
\hline $4 \mathrm{H}-1,94$ & 27.44 & 2.8 & 138.7 & 136.6 & 2.1 & $4 \mathrm{R}-2,114$ & 116.54 & 0.0 & 0.1 & 0.0 \\
\hline $4 \mathrm{H}-2,16$ & 28.16 & 0.3 & 19.5 & 19.1 & 0.4 & $5 \mathrm{R}-1,41$ & 124.01 & 0.0 & 0.0 & 0.0 \\
\hline $4 \mathrm{H}-2,91$ & 28.91 & 0.0 & 0.0 & 0.0 & $\begin{array}{l}0.4 \\
0.0\end{array}$ & $6 \mathrm{R}-1,41$ & 133.61 & 0.0 & 0.0 & 0.0 \\
\hline $4 \mathrm{H}-2,120$ & 29.20 & 0.2 & 0.1 & 0.1 & 0.0 & $6 \mathrm{R}-3,116$ & 137.36 & 0.0 & 0.0 & 0.0 \\
\hline $4 \mathrm{H}-3,77$ & 30.27 & 0.1 & 0.0 & 0.0 & 0.0 & $7 \mathrm{R}-1,115$ & 144.05 & 0.0 & 0.0 & 0.0 \\
\hline $4 \mathrm{H}-3,120$ & 30.70 & 0.0 & 0.0 & 0.0 & 0.0 & $7 \mathrm{R}-4,41$ & 149.29 & 0.2 & 0.0 & 0.0 \\
\hline $4 \mathrm{H}-4,34$ & 31.34 & 0.0 & 0.0 & 0.0 & 0.0 & $8 \mathrm{R}-1,117$ & 153.77 & 0.0 & 0.0 & 0.0 \\
\hline $4 \mathrm{H}-4,91$ & 31.91 & 0.2 & 1.3 & 1.2 & 0.2 & $8 \mathrm{R}-3,41$ & 156.01 & 0.0 & 0.0 & 0.0 \\
\hline $4 \mathrm{H}-5,16$ & 32.66 & 0.2 & 0.2 & 0.2 & 0.0 & $8 \mathrm{R}-4,114$ & 157.74 & 0.0 & 0.0 & 0.0 \\
\hline $4 \mathrm{H}-6,49$ & 34.49 & 8.9 & 352.3 & 342.1 & $\begin{array}{r}0.0 \\
10.2\end{array}$ & $8 \mathrm{R}-5,41$ & 159.01 & 0.0 & 0.0 & 0.0 \\
\hline $4 \mathrm{H}-6,101$ & 35.01 & 0.0 & 0.0 & 0.0 & 0.0 & $9 \mathrm{R}-1,41$ & 162.71 & 0.0 & 0.0 & 0.0 \\
\hline $4 \mathrm{H}-7,10$ & 35.60 & 0.0 & 0.0 & 0.0 & 0.0 & $9 \mathrm{R}-3,118$ & 166.48 & 0.2 & 0.0 & 0.0 \\
\hline $4 \mathrm{H}-7,27$ & 35.77 & 0.0 & 0.2 & 0.2 & 0.0 & $9 \mathrm{R}-4,41$ & 167.21 & 0.0 & 0.0 & 0.0 \\
\hline $4 \mathrm{H}-\mathrm{CC}, 6$ & 35.90 & 0.0 & 0.0 & 0.0 & 0.0 & $9 R-4,118$ & 167.98 & 0.0 & 0.0 & 0.0 \\
\hline $5 \mathrm{H}-1,10$ & 36.10 & 0.0 & 1.1 & 1.1 & 0.0 & $10 \mathrm{R}-1,41$ & 172.31 & 0.0 & 0.0 & 0.0 \\
\hline $5 \mathrm{H}-1,35$ & 36.35 & 0.1 & 1.2 & 0.6 & 0.6 & $10 \mathrm{R}-6,116$ & 181.26 & 0.0 & 0.0 & 0.0 \\
\hline $5 \mathrm{H}-2,10$ & 37.60 & 0.0 & 0.0 & 0.0 & $\begin{array}{l}0.0 \\
0.0\end{array}$ & $11 \mathrm{R}-1,41$ & 182.01 & 0.0 & 0.0 & 0.0 \\
\hline $5 \mathrm{H}-2,47$ & 37.97 & 0.0 & 0.1 & 0.1 & 0.0 & $12 \mathrm{R}-2,40$ & 193.04 & 0.0 & 0.0 & 0.0 \\
\hline $5 \mathrm{H}-4,91$ & 41.41 & 0.0 & 0.0 & 0.0 & 0.0 & $12 \mathrm{R}-3,40$ & 194.54 & 0.6 & 0.2 & 0.0 \\
\hline
\end{tabular}


Table 2.3 (continued).

\begin{tabular}{|c|c|c|c|c|c|}
\hline $\begin{array}{l}\text { Core, section, } \\
\text { interval }(\mathrm{cm})\end{array}$ & $\begin{array}{l}\text { Depth } \\
\text { (mbsf) }\end{array}$ & $\begin{array}{c}\text { Benthic } \\
\text { foraminifers } \\
\text { (spec./g) }\end{array}$ & $\begin{array}{c}\text { Planktonic } \\
\text { foraminifers } \\
\text { (spec./g) }\end{array}$ & $\begin{array}{l}\text { N. pachyderma } \\
\text { sinistral } \\
\text { (spec./g) }\end{array}$ & $\begin{array}{c}\text { Subpolar } \\
\text { planktonic } \\
\text { foraminifers } \\
\text { (spec./g) }\end{array}$ \\
\hline $13 \mathrm{R}-1,117$ & 201.97 & 0.0 & 0.0 & 0.0 & 0.0 \\
\hline 13R-2, 41 & 202.71 & 0.0 & 0.0 & 0.0 & 0.0 \\
\hline $14 \mathrm{R}-1,41$ & 210.91 & 1.1 & 0.4 & 0.0 & 0.4 \\
\hline $14 \mathrm{R}-2,116$ & 212.16 & 0.5 & 0.1 & 0.0 & 0.1 \\
\hline $14 R-5,41$ & 216.91 & 0.1 & 0.0 & 0.0 & 0.0 \\
\hline $15 \mathrm{R}-1,41$ & 220.51 & 0.0 & 0.0 & 0.0 & 0.0 \\
\hline $15 \mathrm{R}-2,116$ & 222.76 & 0.0 & 0.0 & 0.0 & 0.0 \\
\hline $15 \mathrm{R}-4,116$ & 225.76 & 1.9 & 2.0 & 0.3 & 1.8 \\
\hline $16 \mathrm{R}-1,41$ & 230.01 & 0.3 & 0.0 & 0.0 & 0.0 \\
\hline $16 \mathrm{R}-2,41$ & 231.51 & 0.0 & 0.0 & 0.0 & 0.0 \\
\hline $16 \mathrm{R}-3,116$ & 233.76 & 0.0 & 0.0 & 0.0 & 0.0 \\
\hline $17 R-1,41$ & 239.61 & 0.0 & 0.0 & 0.0 & 0.0 \\
\hline $17 \mathrm{R}-4,41$ & 244.11 & 0.0 & 0.0 & 0.0 & 0.0 \\
\hline
\end{tabular}


Table 3.1. Number of coccoliths (grain \%) at Site 644.

\begin{tabular}{|c|c|c|c|}
\hline $\begin{array}{l}\text { Core, section, } \\
\text { interval }(\mathrm{cm})\end{array}$ & $\begin{array}{l}\text { Depth } \\
\text { (mbsf) }\end{array}$ & $\begin{array}{l}\text { Coccoliths } \\
\text { (grain\%) }\end{array}$ & $\begin{array}{c}\text { C. pelagicus } \\
\text { (grain } \%)\end{array}$ \\
\hline \multicolumn{4}{|l|}{$104-644 \mathrm{~A}-$} \\
\hline $1 \mathrm{H}-1,3$ & 0.03 & 14.58 & 7.26 \\
\hline $1 \mathrm{H}-1,33$ & 0.33 & 2.21 & 0.57 \\
\hline $1 \mathrm{H}-3,71$ & 3.69 & 1.10 & 0.15 \\
\hline $1 \mathrm{H}-4,132$ & 5.82 & 0.97 & 0.15 \\
\hline $1 \mathrm{H}-6,11$ & 7.61 & 0.61 & 0.31 \\
\hline $2 \mathrm{H}-1,69$ & 9.89 & 0.00 & 0.00 \\
\hline $2 \mathrm{H}-1,112$ & 10.32 & 1.46 & 0.00 \\
\hline $2 \mathrm{H}-1,130$ & 10.50 & 3.49 & 1.34 \\
\hline $2 \mathrm{H}-1,149$ & 10.69 & 14.22 & 1.14 \\
\hline $2 \mathrm{H}-2,9$ & 10.79 & 22.39 & 0.44 \\
\hline $2 \mathrm{H}-2,32$ & 11.02 & 11.06 & 0.38 \\
\hline $2 \mathrm{H}-2,52$ & 11.22 & 3.37 & 0.00 \\
\hline $2 \mathrm{H}-2,74$ & 11.44 & 5.97 & 0.00 \\
\hline $2 \mathrm{H}-2,93$ & 11.63 & 2.00 & 0.69 \\
\hline $2 \mathrm{H}-2,113$ & 11.83 & 11.73 & 0.66 \\
\hline $2 \mathrm{H}-2,130$ & 12.00 & 6.40 & 0.45 \\
\hline $2 \mathrm{H}-3,2$ & 12.22 & 9.15 & 0.00 \\
\hline $2 \mathrm{H}-3,33$ & 12.53 & 6.45 & 0.14 \\
\hline $2 \mathrm{H}-3,49$ & 12.69 & 7.41 & 0.35 \\
\hline $2 \mathrm{H}-3,93$ & 13.13 & 3.46 & 0.00 \\
\hline $2 \mathrm{H}-3,134$ & 13.54 & 6.50 & 0.38 \\
\hline $2 \mathrm{H}-4,14$ & 13.84 & 10.80 & 0.00 \\
\hline $2 \mathrm{H}-4,31$ & 14.01 & 3.74 & 0.19 \\
\hline $2 \mathrm{H}-4,69$ & 14.39 & 0.65 & 0.12 \\
\hline $2 \mathrm{H}-4,104$ & 14.74 & 0.00 & 0.00 \\
\hline $2 \mathrm{H}-4,128$ & 14.98 & 0.90 & 0.45 \\
\hline $3 \mathrm{H}-1,10$ & 16.30 & 0.62 & 0.09 \\
\hline $3 \mathrm{H}-1,82$ & 17.02 & 0.00 & 0.00 \\
\hline $3 \mathrm{H}-2,71$ & 18.41 & 0.71 & 0.27 \\
\hline $3 \mathrm{H}-2,91$ & 18.61 & 0.21 & 0.11 \\
\hline $3 \mathrm{H}-3,71$ & 19.91 & 2.51 & 0.55 \\
\hline $3 \mathrm{H}-4,22$ & 20.92 & 0.00 & 0.00 \\
\hline $3 \mathrm{H}-4,71$ & 21.41 & 0.37 & 0.37 \\
\hline $3 \mathrm{H}-4,111$ & 21.81 & 0.49 & 0.00 \\
\hline $3 \mathrm{H}-4,139$ & 22.09 & 1.37 & 0.00 \\
\hline $3 \mathrm{H}-5,10$ & 22.30 & 6.63 & 0.50 \\
\hline $3 \mathrm{H}-5,73$ & 22.93 & 0.47 & 0.00 \\
\hline $3 \mathrm{H}-5,102$ & 23.22 & 0.00 & 0.00 \\
\hline $3 \mathrm{H}-5,122$ & 23.42 & 0.00 & 0.00 \\
\hline $3 \mathrm{H}-6,10$ & 23.79 & 0.00 & 0.00 \\
\hline $3 \mathrm{H}-6,30$ & 24.00 & 0.00 & 0.00 \\
\hline $3 \mathrm{H}-7,29$ & 25.47 & 0.52 & 0.44 \\
\hline $4 \mathrm{H}-1,13$ & 25.83 & 0.00 & 0.00 \\
\hline $4 \mathrm{H}-1,52$ & 26.22 & 0.00 & 0.00 \\
\hline $4 \mathrm{H}-1,73$ & 26.43 & 0.38 & 0.38 \\
\hline $4 \mathrm{H}-2,32$ & 27.52 & 0.33 & 0.33 \\
\hline $4 \mathrm{H}-2,52$ & 27.72 & 1.42 & 0.51 \\
\hline $4 \mathrm{H}-2,112$ & 28.32 & 0.00 & 0.00 \\
\hline $4 \mathrm{H}-3,13$ & 28.83 & 0.00 & 0.00 \\
\hline $4 \mathrm{H}-3,42$ & 29.12 & 0.00 & 0.00 \\
\hline $4 \mathrm{H}-3,122$ & 29.92 & 0.00 & 0.00 \\
\hline $4 \mathrm{H}-4,33$ & 30.53 & 0.65 & 0.19 \\
\hline $4 \mathrm{H}-4,52$ & 30.72 & 0.18 & 0.00 \\
\hline $4 \mathrm{H}-1,13$ & 31.83 & 1.56 & 0.09 \\
\hline $4 \mathrm{H}-5,52$ & 32.22 & 0.00 & 0.00 \\
\hline $4 \mathrm{H}-5,102$ & 32.72 & 0.00 & 0.00 \\
\hline $4 \mathrm{H}-5,142$ & 33.12 & 0.00 & 0.00 \\
\hline $4 \mathrm{H}-6,13$ & 33.33 & 0.00 & 0.00 \\
\hline $4 \mathrm{H}-6,60$ & 33.80 & 0.00 & 0.00 \\
\hline $5 \mathrm{H}-1,22$ & 35.42 & 0.00 & 0.00 \\
\hline $5 \mathrm{H}-1,102$ & 36.22 & 0.00 & 0.00 \\
\hline $5 \mathrm{H}-1,141$ & 36.61 & 0.00 & 0.00 \\
\hline $5 \mathrm{H}-2,22$ & 36.92 & 0.00 & 0.00 \\
\hline $5 \mathrm{H}-2,53$ & 37.23 & 0.10 & 0.00 \\
\hline $5 \mathrm{H}-2,69$ & 37.39 & 0.87 & 0.00 \\
\hline $5 \mathrm{H}-2,88$ & 38.58 & 0.74 & 0.15 \\
\hline $5 \mathrm{H}-2,111$ & 37.81 & 0.37 & 0.00 \\
\hline $5 \mathrm{H}-3,13$ & 38.43 & 0.50 & 0.14 \\
\hline $5 \mathrm{H}-3,69$ & 38.89 & 0.39 & 0.00 \\
\hline $5 \mathrm{H}-3,111$ & 39.31 & 1.16 & 0.10 \\
\hline
\end{tabular}

\begin{tabular}{|c|c|c|c|}
\hline $\begin{array}{l}\text { Core, section, } \\
\text { interval }(\mathrm{cm})\end{array}$ & $\begin{array}{l}\text { Depth } \\
\text { (mbsf) }\end{array}$ & $\begin{array}{c}\text { Coccoliths } \\
\text { (grain\%) }\end{array}$ & $\begin{array}{c}\text { C. pelagicus } \\
\text { (grain\%) }\end{array}$ \\
\hline $5 H-4,11$ & 39.81 & 1.06 & 0.00 \\
\hline $5 \mathrm{H}-4,31$ & 40.01 & 1.16 & 0.08 \\
\hline $5 \mathrm{H}-5,149$ & 42.69 & 0.48 & 0.00 \\
\hline $6 \mathrm{H}-1,11$ & 44.81 & 1.91 & 0.07 \\
\hline $6 \mathrm{H}-1,78$ & 45.48 & 0.00 & 0.00 \\
\hline $6 \mathrm{H}-1,122$ & 45.90 & 0.00 & 0.00 \\
\hline $6 \mathrm{H}-2,65$ & 46.85 & 0.07 & 0.00 \\
\hline $6 \mathrm{H}-3,22$ & 47.92 & 0.00 & 0.00 \\
\hline $6 \mathrm{H}-3,101$ & 48.71 & 0.05 & 0.00 \\
\hline $6 \mathrm{H}-4,11$ & 49.31 & 23.53 & 0.14 \\
\hline $6 \mathrm{H}-4,32$ & 49.52 & 33.11 & 0.12 \\
\hline $6 \mathrm{H}-4,51$ & 49.71 & 8.22 & 0.38 \\
\hline $6 \mathrm{H}-5,22$ & 50.92 & 0.13 & 0.07 \\
\hline $6 \mathrm{H}-5,122$ & 51.92 & 0.00 & 0.00 \\
\hline $6 \mathrm{H}-6,22$ & 52.42 & 0.00 & 0.00 \\
\hline $6 \mathrm{H}-6,66$ & 53.06 & 3.70 & 0.48 \\
\hline $6 \mathrm{H}-6,92$ & 53.13 & 9.05 & 0.00 \\
\hline $6 \mathrm{CC}-18$ & 53.22 & 28.17 & 0.06 \\
\hline $7 \mathrm{H}-1,3$ & 54.23 & 0.00 & 0.00 \\
\hline $7 \mathrm{H}-1,64$ & 54.85 & 0.00 & 0.00 \\
\hline $7 \mathrm{H}-3,64$ & 57.84 & 0.00 & 0.00 \\
\hline $7 \mathrm{H}-4,22$ & 58.92 & 0.00 & 0.00 \\
\hline $8 \mathrm{H}-3,40$ & 67.10 & 0.00 & 0.00 \\
\hline $8 \mathrm{H}-5,22$ & 69.92 & 0.00 & 0.00 \\
\hline $8 \mathrm{H}-5,60$ & 70.30 & 0.00 & 0.00 \\
\hline $8 \mathrm{H}-6,42$ & 71.62 & 0.00 & 0.00 \\
\hline $8 \mathrm{H}-7,3$ & 72.43 & 0.50 & 0.00 \\
\hline $8 \mathrm{H}-7,21$ & 72.79 & 11.67 & 0.10 \\
\hline $9 \mathrm{H}-1,48$ & 73.68 & 4.73 & 0.11 \\
\hline $9 \mathrm{H}-1,69$ & 73.89 & 3.20 & 0.70 \\
\hline $9 \mathrm{H}-1,142$ & 74.62 & 0.00 & 0.00 \\
\hline $9 \mathrm{H}-3,142$ & 77.62 & 0.00 & 0.00 \\
\hline $9 \mathrm{H}-5,40$ & 79.60 & 0.00 & 0.00 \\
\hline $9 \mathrm{CC}-12$ & 82.32 & 0.11 & 0.00 \\
\hline $10 \mathrm{H}-1,13$ & 82.84 & 0.00 & 0.00 \\
\hline $10 \mathrm{H}-2,3$ & 84.23 & 1.53 & 0.07 \\
\hline $10 \mathrm{H}-2,34$ & 84.54 & 12.38 & 0.00 \\
\hline $10 \mathrm{H}-2,67$ & 84.87 & 19.85 & 0.00 \\
\hline $10 \mathrm{H}-2,84$ & 85.04 & 11.88 & 0.00 \\
\hline $10 \mathrm{H}-2,97$ & 85.17 & 27.47 & 0.20 \\
\hline $10 \mathrm{H}-2,130$ & 85.50 & 27.48 & 0.00 \\
\hline $10 \mathrm{H}-3,49$ & 86.19 & 14.29 & 0.00 \\
\hline $10 \mathrm{H}-3,69$ & 86.39 & 16.04 & 0.00 \\
\hline $10 \mathrm{H}-3,92$ & 86.62 & 1.97 & 0.00 \\
\hline $10 \mathrm{H}-3,142$ & 87.12 & 0.00 & 0.00 \\
\hline $10 \mathrm{H}-4,60$ & 87.80 & 0.00 & 0.00 \\
\hline $10 \mathrm{H}-4,109$ & 88.29 & 0.42 & 0.00 \\
\hline $10 \mathrm{H}-4,135$ & 88.55 & 0.46 & 0.00 \\
\hline $10 \mathrm{H}-5,3$ & 88.73 & 0.15 & 0.00 \\
\hline $10 \mathrm{H}-5,29$ & 88.99 & 1.35 & 0.00 \\
\hline $10 \mathrm{H}-5,49$ & 89.19 & 0.61 & 0.00 \\
\hline $10 \mathrm{H}-5,68$ & 89.38 & 0.96 & 0.00 \\
\hline $10 \mathrm{H}-5,135$ & 90.05 & 0.00 & 0.00 \\
\hline $10 \mathrm{H}-6,58$ & 90.78 & 0.00 & 0.00 \\
\hline $11 \mathrm{H}-1,100$ & 93.20 & 0.07 & 0.00 \\
\hline $11 \mathrm{H}-1,142$ & 93.62 & 0.00 & 0.00 \\
\hline $11 \mathrm{H}-2,81$ & 94.51 & 0.13 & 0.00 \\
\hline $11 \mathrm{H}-3,49$ & 95.69 & 0.59 & 0.00 \\
\hline $11 \mathrm{H}-3,68$ & 95.88 & 0.00 & 0.00 \\
\hline $11 \mathrm{H}-3,129$ & 96.49 & 0.13 & 0.00 \\
\hline $11 \mathrm{H}-4,10$ & 96.80 & 0.00 & 0.00 \\
\hline $11 \mathrm{H}-4,29$ & 96.99 & 0.46 & 0.00 \\
\hline $11 \mathrm{H}-4,49$ & 97.19 & 0.52 & 0.00 \\
\hline $11 \mathrm{H}-4,88$ & 97.58 & 0.13 & 0.00 \\
\hline $11 \mathrm{H}-4,122$ & 97.92 & 0.00 & 0.00 \\
\hline $11 \mathrm{H}-5,60$ & 98.80 & 0.00 & 0.00 \\
\hline $11 \mathrm{H}-5,100$ & 99.20 & 0.00 & 0.00 \\
\hline $11 \mathrm{H}-6,135$ & 100.90 & 3.40 & 0.00 \\
\hline $11 \mathrm{H}-7,10$ & 101.30 & 4.90 & 0.00 \\
\hline $12 \mathrm{H}-1,22$ & 101.90 & 0.00 & 0.00 \\
\hline $12 \mathrm{H}-1,142$ & 103.10 & 0.00 & 0.00 \\
\hline
\end{tabular}

\begin{tabular}{|c|c|c|c|}
\hline $\begin{array}{l}\text { Core, section, } \\
\text { interval }(\mathrm{cm})\end{array}$ & $\begin{array}{l}\text { Depth } \\
\text { (mbsf) }\end{array}$ & $\begin{array}{l}\text { Coccoliths } \\
\text { (grain\%) }\end{array}$ & $\begin{array}{c}\text { C. pelagicus } \\
\text { (grain\%) }\end{array}$ \\
\hline $12 \mathrm{H}-2,42$ & 103.50 & 0.00 & 0.00 \\
\hline $12 \mathrm{H}-2,110$ & 104.30 & 5.06 & 0.00 \\
\hline $12 \mathrm{H}-2,127$ & 104.47 & 5.20 & 0.00 \\
\hline $12 \mathrm{H}-3,22$ & 104.90 & 0.00 & 0.00 \\
\hline $12 \mathrm{H}-3,102$ & 105.70 & 0.00 & 0.00 \\
\hline $12 \mathrm{H}-3,142$ & 106.10 & 0.00 & 0.00 \\
\hline $12 \mathrm{H}-4,52$ & 106.70 & 0.00 & 0.00 \\
\hline $12 \mathrm{H}-4,73$ & 106.90 & 5.07 & 0.00 \\
\hline $12 \mathrm{H}-4,102$ & 107.20 & 0.00 & 0.00 \\
\hline $12 \mathrm{H}-5,22$ & 107.90 & 0.00 & 0.00 \\
\hline $12 \mathrm{H}-5,102$ & 108.70 & 0.00 & 0.00 \\
\hline $12 \mathrm{H}-6,60$ & 109.80 & 0.00 & 0.00 \\
\hline $12 \mathrm{H}-6,111$ & 110.30 & 7.18 & 0.00 \\
\hline $12 \mathrm{H}-6,137$ & 110.64 & 5.48 & 0.00 \\
\hline $13 \mathrm{H}-1,3$ & 111.63 & 1.09 & 0.00 \\
\hline $13 \mathrm{H}-3,83$ & 114.75 & 0.00 & 0.00 \\
\hline $13 \mathrm{H}-4.87$ & 116.60 & 0.00 & 0.00 \\
\hline $14 \mathrm{H}-2,56$ & 122.80 & 0.00 & 0.00 \\
\hline $14 \mathrm{H}-4,62$ & 125.80 & 0.00 & 0.00 \\
\hline $14 \mathrm{H}-5,62$ & 127.30 & 0.00 & 0.00 \\
\hline $15 \mathrm{H}-2,42$ & 132.09 & 0.00 & 0.00 \\
\hline $15 \mathrm{H}-2,142$ & 133.10 & 0.00 & 0.00 \\
\hline $15 \mathrm{H}-4,62$ & 135.31 & 0.00 & 0.00 \\
\hline $15 \mathrm{H}-5,42$ & 136.60 & 1.00 & 0.80 \\
\hline $15 \mathrm{H}-7,62$ & 139.80 & 0.00 & 0.00 \\
\hline $16 \mathrm{H}-1,62$ & 140.50 & 8.80 & 4.80 \\
\hline $16 \mathrm{H}-1,82$ & 140.60 & 11.38 & 8.19 \\
\hline $16 \mathrm{H}-2,102$ & 142.24 & 0.00 & 0.00 \\
\hline $16 \mathrm{H}-3,82$ & 143.54 & 2.33 & 0.67 \\
\hline $16 \mathrm{H}-4,23$ & 144.44 & 0.00 & 0.00 \\
\hline $16 \mathrm{H}-4,42$ & 144.82 & 0.00 & 0.00 \\
\hline $16 \mathrm{H}-4,62$ & 145.02 & 7.28 & 0.78 \\
\hline $16 \mathrm{H}-4,82$ & 145.54 & 7.45 & 0.91 \\
\hline $16 \mathrm{H}-5,23$ & 146.55 & 0.00 & 0.00 \\
\hline $16 \mathrm{H}-5,62$ & 146.98 & 0.20 & 0.00 \\
\hline $16 \mathrm{H}-5,82$ & 147.19 & 0.00 & 0.00 \\
\hline $16 \mathrm{H}-6,60$ & 148.60 & 0.00 & 0.00 \\
\hline $17 \mathrm{H}-1.23$ & 149.40 & 0.00 & 0.00 \\
\hline $17 \mathrm{H}-1,122$ & 150.40 & 0.00 & 0.00 \\
\hline $17 \mathrm{H}-4.13$ & 154.08 & 0.00 & 0.00 \\
\hline $17 \mathrm{H}-4,62$ & 154.59 & 6.75 & 1.25 \\
\hline $17 \mathrm{H}-5,42$ & 156.30 & 3.58 & 1.64 \\
\hline $18 \mathrm{H}-1,42$ & 159.12 & 0.00 & 0.00 \\
\hline $18 \mathrm{H}-2,42$ & 160.62 & 0.00 & 0.00 \\
\hline $18 \mathrm{H}-2,102$ & 161.22 & 0.00 & 0.00 \\
\hline $18 \mathrm{H}-4,102$ & 164.23 & 0.00 & 0.00 \\
\hline $19 \mathrm{H}-4,22$ & 175.01 & 0.00 & 0.00 \\
\hline $20 \mathrm{H}-1,42$ & 178.12 & 0.00 & 0.00 \\
\hline $18 \mathrm{H}-7,42$ & 168.13 & 0.00 & 0.00 \\
\hline $18 \mathrm{H}-4,42$ & 163.62 & 0.00 & 0.00 \\
\hline $18 \mathrm{H}-4,102$ & 164.23 & 0.00 & 0.00 \\
\hline $21 \mathrm{H}-1,62$ & 175.56 & 0.00 & 0.00 \\
\hline $20 \mathrm{H}-2,102$ & 180.24 & 1.50 & 1.30 \\
\hline $20 \mathrm{H}-3,122$ & 181.95 & 0.00 & 0.00 \\
\hline $21 \mathrm{H}-1,62$ & 185.39 & 0.00 & 0.00 \\
\hline $22 \mathrm{H}-3,62$ & 190.24 & 0.00 & 0.00 \\
\hline $22 \mathrm{H}-4,82$ & 191.86 & 2.63 & 2.25 \\
\hline $23 \mathrm{H}-3,42$ & 197.12 & 0.00 & 0.00 \\
\hline $23 \mathrm{H}-4,42$ & 198.45 & 0.00 & 0.00 \\
\hline $24 \mathrm{H}-1,102$ & 202.11 & 0.00 & 0.00 \\
\hline $25 \mathrm{H}-\mathrm{I}, 82$ & 206.91 & 0.00 & 0.00 \\
\hline $26 \mathrm{H}-1,22$ & 210.72 & 0.00 & 0.00 \\
\hline $27 \mathrm{H}-1,102$ & 215.30 & 0.00 & 0.00 \\
\hline $28 \mathrm{H}-3,102$ & 219.81 & 0.00 & 0.00 \\
\hline $29 \mathrm{H}-3,102$ & 225.14 & 0.00 & 0.00 \\
\hline $30 \mathrm{H}-4,102$ & 231.62 & 0.00 & 0.00 \\
\hline $31 \mathrm{H}-3,60$ & 235.91 & 0.00 & 0.00 \\
\hline $32 \mathrm{H}-2,62$ & 240.22 & 15.98 & 2.50 \\
\hline $32 \mathrm{H}-2,106$ & 240.63 & 0.50 & 0.10 \\
\hline $33 \mathrm{H}-1,102$ & 244.70 & 12.30 & 1.00 \\
\hline $34 \mathrm{H}-2,65$ & 248.20 & 0.00 & 0.00 \\
\hline
\end{tabular}


Table 3.2. Number of coccoliths (grain \%) at Site 907.

\begin{tabular}{|c|c|c|c|c|c|c|c|}
\hline $\begin{array}{l}\text { Core, section, } \\
\text { interval }(\mathrm{cm})\end{array}$ & $\begin{array}{l}\text { Depth } \\
\text { (mbsf) }\end{array}$ & $\begin{array}{l}\text { Coccoliths } \\
\text { (grain\%) }\end{array}$ & $\begin{array}{c}\text { C. pelagicus } \\
\text { (grain\%) }\end{array}$ & $\begin{array}{l}\text { Core, section, } \\
\text { interval }(\mathrm{cm})\end{array}$ & $\begin{array}{l}\text { Depth } \\
\text { (mbsf) }\end{array}$ & $\begin{array}{c}\text { Coccoliths } \\
\text { (grain\%) }\end{array}$ & $\begin{array}{l}\text { C. pelagicus } \\
\text { (grain } \%)\end{array}$ \\
\hline $151-907 \mathrm{~A}-$ & & & & $2 \mathrm{H}-2,43$ & 9.23 & 0.00 & 0.00 \\
\hline $1 \mathrm{H}-1,8$ & 0.08 & 13.78 & 11.26 & $2 \mathrm{H}-2,82$ & 9.62 & 0.00 & 0.00 \\
\hline $1 \mathrm{H}-1,14$ & 0.14 & 12.68 & 11.17 & $2 \mathrm{H}-2,135$ & 10.15 & 0.00 & 0.00 \\
\hline IH-1, 24 & 0.24 & 0.65 & 0.51 & $2 \mathrm{H}-3,5$ & 10.35 & 0.00 & 0.00 \\
\hline $1 \mathrm{H}-1,35$ & 0.35 & 0.33 & 0.13 & $2 \mathrm{H}-3,16$ & 10.46 & 0.00 & 0.00 \\
\hline $1 \mathrm{H}-1,56$ & 0.56 & 0.16 & 0.05 & $2 \mathrm{H}-3,24$ & 10.54 & 1.58 & 0.12 \\
\hline $1 \mathrm{H}-1,71$ & 0.71 & 0.00 & 0.00 & $2 \mathrm{H}-3,30$ & 10.60 & 10.60 & 0.10 \\
\hline IH-1, 94 & 0.94 & 0.00 & 0.00 & $2 \mathrm{H}-3,75$ & 11.05 & 0.25 & 0.08 \\
\hline IH-1, 135 & 1.35 & 0.20 & 0.13 & $2 \mathrm{H}-3,93$ & 11.23 & 0.00 & 0.00 \\
\hline $1 \mathrm{H}-2,11$ & 1.61 & 0.77 & 0.31 & $2 \mathrm{H}-3,108$ & 11.38 & 0.21 & 0.00 \\
\hline $1 \mathrm{H}-2,25$ & 1.75 & 3.51 & 0.10 & $2 \mathrm{H}-3,135$ & 11.65 & 0.00 & 0.00 \\
\hline $1 \mathrm{H}-2,35$ & 1.85 & 1.23 & 0.08 & $2 \mathrm{H}-4,31$ & 12.11 & 0.00 & 0.00 \\
\hline $1 \mathrm{H}-2,45$ & 1.95 & 6.69 & 0.46 & $2 \mathrm{H}-4,80$ & 12.60 & 0.00 & 0.00 \\
\hline $1 \mathrm{H}-2,55$ & 2.05 & 1.44 & 0.18 & $2 \mathrm{H}-4,135$ & 13.15 & 0.00 & 0.00 \\
\hline $1 \mathrm{H}-2,65$ & 2.15 & 2.88 & 2.80 & $2 \mathrm{H}-5,15$ & 13.45 & 0.15 & 0.08 \\
\hline $1 \mathrm{H}-2,75$ & 2.25 & 0.00 & 0.00 & $2 \mathrm{H}-5,36$ & 13.66 & 0.00 & 0.00 \\
\hline $1 \mathrm{H}-2,85$ & 2.35 & 0.00 & 0.00 & $2 \mathrm{H}-5,85$ & 14.15 & 0.00 & 0.00 \\
\hline $1 \mathrm{H}-2,110$ & 2.60 & 0.00 & 0.00 & $2 \mathrm{H}-5,110$ & 14.40 & 0.00 & 0.00 \\
\hline $1 \mathrm{H}-2,127$ & 2.77 & 0.13 & 0.00 & $2 \mathrm{H}-6,5$ & 14.85 & 0.00 & 0.00 \\
\hline $\mathrm{IH}-2,143$ & 2.93 & 0.07 & 0.00 & $2 \mathrm{H}-6,65$ & 15.45 & 0.00 & 0.00 \\
\hline $1 \mathrm{H}-3,5$ & 3.05 & 0.13 & 0.07 & $2 \mathrm{H}-7,10$ & 16.40 & 0.00 & 0.00 \\
\hline $1 \mathrm{H}-3,16$ & 3.16 & 0.00 & 0.00 & $2 \mathrm{H}-7,19$ & 16.49 & 0.00 & 0.00 \\
\hline $\mathrm{IH}-3,26$ & 3.26 & 0,30 & 0.10 & $2 \mathrm{H}-7,35$ & 16.65 & 0.08 & 0.08 \\
\hline IH- 3,40 & 3.40 & 0.00 & 0.00 & $3 \mathrm{H}-1,32$ & 17.12 & 0.00 & 0.00 \\
\hline $1 \mathrm{H}-3,66$ & 3.66 & 0.00 & 0.00 & $3 \mathrm{H}-2,31$ & 18.61 & 0.00 & 0.00 \\
\hline $1 \mathrm{H}-3,76$ & 3.76 & 0.00 & 0.00 & $3 \mathrm{H}-2,105$ & 19.35 & 0.00 & 0.00 \\
\hline $1 \mathrm{H}-3,99$ & 3.99 & 6.18 & 4.93 & $3 \mathrm{H}-3,41$ & 20.21 & 0.00 & 0.00 \\
\hline $1 \mathrm{H}-3,106$ & 4.06 & 1.60 & 1.26 & $3 \mathrm{H}-4,25$ & 21.55 & 0.00 & 0.00 \\
\hline $1 \mathrm{H}-3,120$ & 4.20 & 0.13 & 0.13 & $3 \mathrm{H}-5,61$ & 23.41 & 0.00 & 0.00 \\
\hline $1 \mathrm{H}-3,147$ & 4.47 & 0.22 & 0.11 & $3 \mathrm{H}-6,25$ & 24.55 & 0.00 & 0.00 \\
\hline $1 \mathrm{H}-4,10$ & 4.60 & 0.00 & 0.00 & $3 \mathrm{H}-7,10$ & 25.90 & 0.00 & 0.00 \\
\hline $1 \mathrm{H}-4,23$ & 4.73 & 0.36 & 0.27 & $4 \mathrm{H}-1,78$ & 27.08 & 0.00 & 0.00 \\
\hline $1 \mathrm{H}-4,35$ & 4.85 & 0.11 & 0.06 & $4 \mathrm{H}-2,102$ & 28.82 & 0.00 & 0.00 \\
\hline $1 \mathrm{H}-4,44$ & 4.94 & 0.00 & 0.00 & $4 \mathrm{H}-3,110$ & 30.40 & 0.00 & 0.00 \\
\hline $1 \mathrm{H}-4,55$ & 5.05 & 1.58 & 0.00 & $4 \mathrm{H}-4,15$ & 30.95 & 0.15 & 0.08 \\
\hline $1 \mathrm{H}-4,85$ & 5.35 & 0.00 & 0.00 & $4 \mathrm{H}-4,31$ & 31.11 & 0.00 & 0.00 \\
\hline $1 \mathrm{H}-4,110$ & 5.60 & 0.00 & 0.00 & $4 \mathrm{H}-4,135$ & 32.15 & 0.00 & 0.00 \\
\hline $1 \mathrm{H}-4,135$ & 5.85 & 0.00 & 0.00 & $4 \mathrm{H}-5,25$ & 32.55 & 0.08 & 0.08 \\
\hline $1 \mathrm{H}-5,16$ & 6.16 & 0.20 & 0.00 & $4 \mathrm{H}-5,55$ & 32.85 & 0.00 & 0.00 \\
\hline $1 \mathrm{H}-5,54$ & 6.54 & 12.53 & 0.13 & $4 \mathrm{H}-6,65$ & 34.45 & 0.00 & 0.00 \\
\hline $1 \mathrm{H}-5,65$ & 6.65 & 19.73 & 0.34 & $4 \mathrm{H}-7,69$ & 35.89 & 0.00 & 0.00 \\
\hline $1 \mathrm{H}-5,68$ & 6.68 & 10.58 & 0.58 & $5 \mathrm{H}-2,19$ & 37.49 & 0.00 & 0.00 \\
\hline $1 \mathrm{H}-5,75$ & 6.75 & 0.00 & 0.00 & $5 \mathrm{H}-3,10$ & 38.90 & 0.00 & 0.00 \\
\hline $1 \mathrm{H}-5,80$ & 6.80 & 0.00 & 0.00 & $5 \mathrm{H}-4,90$ & 41.20 & 0.00 & 0.00 \\
\hline $1 \mathrm{H}-5,86$ & 6.86 & 0.00 & 0.00 & $5 \mathrm{H}-5,90$ & 42.70 & 0.00 & 0.00 \\
\hline IH-CC, 8 & 7.08 & 0.00 & 0.00 & $5 \mathrm{H}-7,18$ & 44.98 & 0.00 & 0.00 \\
\hline $2 \mathrm{H}-1,31$ & 7.61 & 0.00 & 0.00 & $6 \mathrm{H}-1,110$ & 46.40 & 0.00 & 0.00 \\
\hline $2 \mathrm{H}-1,65$ & 7.95 & 0.00 & 0.00 & $6 \mathrm{H}-2,90$ & 47.70 & 0.00 & 0.00 \\
\hline $2 \mathrm{H}-1,110$ & 8.40 & 0.20 & 0.10 & $6 \mathrm{H}-3,102$ & 49.32 & 0.00 & 0.00 \\
\hline $2 \mathrm{H}-1,126$ & 8.56 & 0.00 & 0.00 & $6 \mathrm{H}-4,110$ & 50.90 & 0.00 & 0.00 \\
\hline $2 \mathrm{H}-1,144$ & 8.74 & 0.00 & 0.00 & $6 \mathrm{H}-6,31$ & 53.11 & 0.00 & 0.00 \\
\hline $2 \mathrm{H}-2,4$ & 8.84 & 0.00 & 0.00 & $7 \mathrm{H}-1,48$ & 55.28 & 0.00 & 0.00 \\
\hline $2 \mathrm{H}-2,16$ & 8.96 & 1.38 & 0.07 & $7 \mathrm{H}-2,9$ & 56.39 & 0.00 & 0.00 \\
\hline $2 \mathrm{H}-2,28$ & 9.08 & 1.65 & 0.00 & $7 \mathrm{H}-3,49$ & 58.29 & 26.90 & 26.06 \\
\hline $2 \mathrm{H}-2,31$ & 9.11 & 0.00 & 0.00 & $7 \mathrm{H}-4,90$ & 60.20 & 0.00 & 0.00 \\
\hline
\end{tabular}

